$$
\text { UNIVERSIDADE DE SÃO PAULO }
$$

FACULDADE DE FILOSOFIA, LETRAS E CIÊNCIAS HUMANAS DEPARTAMENTO DE GEOGRAFIA

PROGRAMA DE PÓS-GRADUAÇÃO EM GEOGRAFIA HUMANA

\title{
O CURRÍCULO DE GEOGRAFIA: UMA ANÁLISE DO DOCUMENTO DE REORIENTAÇÃO CURRICULAR DA SEE-RJ
}

WASHINGTON ALDY FERREIRA 
UNIVERSIDADE DE SÃO PAULO

FACULDADE DE FILOSOFIA, LETRAS E CIÊNCIAS HUMANAS

DEPARTAMENTO DE GEOGRAFIA

PROGRAMA DE PÓS-GRADUAÇÃO EM GEOGRAFIA HUMANA

\title{
O CURRÍCULO DE GEOGRAFIA: UMA ANÁLISE DO DOCUMENTO DE REORIENTAÇÃO CURRICULAR DA SEE-RJ.
}

\section{WASHINGTON ALDY FERREIRA}

\begin{abstract}
Dissertação de mestrado apresentada ao Programa de Pós-Graduação da Faculdade de Filosofia Letras e Ciências Humanas da USP $\mathrm{Na}$ Área de Geografia Humana como requisito final para obtenção do título de Mestre em Geografia
\end{abstract}

Orientadora: Prof. a Dr. ${ }^{a}$ Sônia Maria Vanzella Castellar 
AUTORIZO A REPRODUÇÃO E DIVULGAÇÃO TOTAL OU PARCIAL, DESTE TRABALHO, POR QUALQUER MEIO CONVENCIONAL OU ELETRÔNICO PARA FINS DE ESTUDO E PESQUISA, DESTE QUE CITADA A FONTE.

Catalogação na Publicação

Serviço de Documentação

Faculdade de Filosofia Letras e Ciências Humanas da Universidade de São Paulo

Ferreira, Washington Aldy.

O currículo de Geografia uma análise do documento de Reorientação Curricular da SEE-RJ./ Washington Aldy Ferreira; orientadora: Sônia Maria Vanzella Castellar São Paulo, 2009.

p. $\mathrm{xxx}$

Dissertação (Mestrado - Programa de Pós-Graduação em Geografia Humana. Faculdade de Filosofia Letras e Ciências Humanas da Universidade de São Paulo.

1. Currículo. 2. Políticas Públicas em Educação. 3. Ensino de Geografia.

4. Neoliberalismo. 5. Espaço vivido. 


\section{DEDICATÓRIA ESPECIAL 1}

À Minha família.

Marlene de Paula que me deu sempre muita força nesta empreitada e esteve sempre presente ao meu lado nos momentos mais complicados.

Ao meu pai, que educou o filho para ser um homem com princípios de solidariedade, respeito ao ser humano e honestidade. Pai você é uma pessoa admirável.

A minha mão que sempre cuidou dos filhos com muito amor.

Aos meus irmãos, parte da minha vida, das brincadeiras e brigas de infância.

DEDICATÓRIA ESPECIAL 2

(In Memorian)

Ao Cláudio Barbosa da Costa grande amigo que se foi muito cedo e inesperadamente. Você faz falta nos encontros, nas rodas de samba, dentro da Uerj-FFP, nos debates sobre a Geografia, etc. etc. etc.

A Marta Ramischaid, Grandessíssima amiga, colega, professora que se foi, também, de forma inesperada. Marta a saudade é muito grande, você faz muita falta. 


\section{AGRADECIMENTOS}

À universidade de São de Paulo e ao Departamento de Geografia que me deram a oportunidade para realizar um trabalho muito importante para minha vida pessoal e carreira profissional.

À Todos os meus amigos que me ajudaram nesta caminhada e acreditaram no meu potencial.

À Santana, grande amigo que me deu muita força. Grandessíssimo companheiro de viagens à São Paulo, de papos geniais turbinado a cerveja nos botecos e padarias de São Paulo. Santana na USP você foi um verdadeiro "Pai Santana” tendo contribuído com altas dicas e no final deste trabalho foi uma mente "santa".

À Marcos do Couto grande camarada e amigo que contribuiu com a sua humildade revolucionária neste trabalho. Marcos você é um sujeito que vale ouro.

As minhas amigas de São Paulo: Ana Claudia e Jerusa sempre presentes nas minhas idas á Sampa.

Ao grande amigo de longa data, companheiro desde o movimento estudantil que vive igual a um cigano pelo país e que ultimamente acolheu-me nas idas a Sampa, em sua casa. Heitor tú é doido.

A outro amigo das antigas, hoje professor desta casa, Manoel Fernandes.

Ao diretor e amigo, Josimar Costa, do Colégio Estadual Maranhão que me ajudou na análise e entrega de documentos relativos ao "Programa Nova Escola" e a "Reorientação Curricular”. Você Josimar é um grande diretor e amigo solidário com os colegas de profissão.

Aos dois Moreiras. O grande Ruy Moreira que influenciou, na graduação, um número significativo de estudantes da geração, da qual faço parte, com sua inteligência e humildade. Ruy você é uma pessoa fantástica. E ao Antônio Flávio Moreira, sua disciplina sobre currículo na UERJ - FEBEF foi de grande valia, uma luz no fim do túnel que efetivamente clareou todo o percurso. Antônio Flávio você é dez.

A amiga Elizete dos Santos Jorge que me ajudou, sempre, nos momentos certos. Parecia um "Cocada" que entrava no final do jogo e resolvia o problema. Suas dicas foram importantíssimas.

Para os professores que efetivamente contribuíram na minha formação e na construção do meu currículo. Carlos Walter Porto Gonçalves, Jorge Luís Barbosa, 
Rogério Haesbaert, Jaílson de Souza Silva, Marcio Piñon. Sem vocês não haveria o geógrafo Washington A. Ferreira.

Não posso deixar de esquecer dos colegas do Departamento de Geografia da UERJ-FFP que durante dois anos e meio me acolheram como professor substituto. Essa experiência foi de grande valia e muito importante para o meu crescimento acadêmico e profissional.

Aos amigos Jorge Braga, Eduardo Karol, Renato Negão e Breguelé. Esse povo que conheci na universidade enquanto estudante e cuja amizade se estende nas relações de trabalho e militância.

Para terminar, gostaria de agradecer a duas pessoas importantíssimas neste processo, sem elas não haveria esta pesquisa e nem esse novo geógrafo. Agradeço do fundo da minha alma a minha querida orientadora Sônia Maria Vanzella Castellar e ao meu grande amigo Charlles da França.

Charlles, você é uma figura, uma criatura que vale ouro. Grande amigo. $O$ cidadão no mundo que possui um amigo como você companheiro, não precisa de mais nada. Sua ajuda e incentivo foram fundamentais para esta empreitada. Você sempre me “perturbou” à fazer esta encrenca, acreditou mais em mim do que eu mesmo. Agora companheiro, dedico grande parte deste trabalho a você... GRANDE AMIGO GRANDE IRMÃO.

Sônia você sempre foi comigo uma pessoa espetacular, que sempre me deu força para ir a São Paulo fazer o mestrado. Sempre me incentivou e me cativou a iniciar esta empreitada. Depois, no mestrado teve que me aturar lendo meus textos, sempre, no “atacado”. Sônia, sua contribuição sempre foi muito valiosa e de grande pertinência. Sei que dei muito trabalho para ti, mas nunca propositalmente. 


\section{Resumo}

Trata-se de uma pesquisa sobre o currículo de Geografia da Secretaria de Educação do Estado do Rio de Janeiro, com o objetivo de analisar a construção da geografia escolar inserida no documento de Reorientação Curricular deste órgão oficial. Neste trabalho, o currículo de Geografia é analisado no atual contexto de transformações do mundo da educação pela perspectiva neoliberal. Tal contexto é marcado por transformações na educação brasileira que ocorre a partir da criação Lei de Diretrizes de Base Nacional (9.394/96), das reformas curriculares como os Parâmetros Curriculares Nacionais para os níveis fundamental e médio, das Diretrizes Curriculares Nacionais e dos sistemas de avaliação como o Exame Nacional do Ensino Médio, cujo objetivo é criar um novo modelo de escola e de ensino no país. No estado do Rio de Janeiro, essas transformações ocorreram dentro de uma mesma lógica global/nacional através de um programa de avaliação das escolas públicas intitulado de "Nova Escola". O currículo de Geografia da Secretaria Estadual de Educação é parte desse contexto. Sua análise é feita através de um diálogo com o campo de estudos sobre currículo e a Geografia acadêmica e escolar brasileira, objetivando compreender as concepções de currículo e de Geografia escolar presentes no documento. A pesquisa aborda as relações existentes entre as políticas educacionais dos organismos multilaterais para os países emergentes, com destaque para o Banco Mundial e sua similaridade com o programa "Nova Escola", assim como os pontos convergentes sobre concepção de currículo entre o Banco e a Secretaria Estadual de Educação do Rio de Janeiro. O trabalho também analisa o currículo de Geografia na perspectiva teórico-metodológica com o intuito de compreender o papel que essa ciência desenvolve na Reorientação Curricular e no programa "Nova Escola".

Palavras-chaves: Currículo, Currículo de Geografia, Políticas públicas de educação, Ensino de Geografia, Neoliberalismo. 


\begin{abstract}
Summary: It is a research about the curriculum implemented by Education Secretary of Rio de Janeiro State, it aims to analyze geography education development within the "Curriculum Guide", which is a document from this official institution. In this assignment, the geography curriculum is analyzed by a current context of changing in education field considering the neoliberal viewpoint. This context is marked by changes in Brazilian education which begins from the creation of the National Curricular Parameters to elementary school and high school, of National Curricular Directives and the new evaluation systems as the National Exam of High School. All these strategies focus on a creation of a new learning model in the basis of the country. In Rio de Janeiro State, these changes occurred in a balanced logic between global and national, through a program which evaluates public schools called " New School ". The geography curriculum of Education Secretary State is part of this context. Its analysis is done by a dialog among the studies field, the Geography College and schools. It aims to understand the conceptions of the curriculum and geography education inside of the document. This research shows the relations among the educational politics from multilateral institutions to developing countries, an important example is the World Bank Group and its similarity with the program "New School". Moreover there are some convergent points about the curriculum conception between the bank and the Education Secretary State of Rio de Janeiro . This essay analyzes the geography curriculum from the theoretical and methodological point of view with the objective of understanding the geography science role considering its development in the "Curriculum Guide" and inside the "New School " program.
\end{abstract}

Key words: curriculum, geography curriculum, Education public politics, Geography learning, neoliberalism 


\section{LISTA DE SIGLAS}

AGB - Associação dos Geógrafos Brasileiros

BID - Banco Interamericano de Desenvolvimento

$\mathrm{BM}$ - Banco Mundial

CEFET-RJ - Centro Federal de Educação Tecnológica do Rio de Janeiro

CNTE - Confederação Nacional dos Trabalhadores em Educação

CUT - Central Única dos Trabalhadores

DCN - Diretrizes Curriculares Nacionais

DCNEM - Diretrizes Curriculares Nacionais Para o Ensino Médio

DEM - Democratas

EF - Educação Fundamental

EJA - Educação de Jovens e Adultos

EM - Ensino Médio

ENADE - Exame Nacional da Educação Superior

ENC - Exame Nacional de Cursos (Provão)

ENEM - Exame Nacional de Ensino Médio

FHC - Fernando Henrique Cardoso

FMI - Fundo Monetário Internacional

FUNDEF - Fundo Nacional de Desenvolvimento da Educação Fundamental

GLP - Gratificação por Lotação Prioritária

LDBEN - Lei de Diretrizes de Bases da Educação Nacional

MEC - Ministério da Educação

PCN - Parâmetros Curriculares Nacionais

PCN+EM - Ensino Médio: orientações complementares aos Parâmetros Curriculares

Nacionais

PCNEM - Parâmetros Curriculares Nacionais Ensino Médio

PDE - Plano de Desenvolvimento da Educação

PFL - Partido da Frente Liberal

PMDB - Partido do Movimento Democrático Brasileiro

PNLD - Programa Nacional do Livro Didático

PNLDEM - Programa Nacional do Livro Didático

PNUD - Programa das Nações Unidas para o Desenvolvimento

PSDB - Partido da Social Democracia Brasileira 
PT - Partido dos Trabalhadores

SAEB - Sistema de Avaliação da Educação Básica

SEE-RJ - Secretaria Estadual de Educação do Rio de Janeiro

SEEDUC-RJ - Secretaria Estadual de Educação do Rio de Janeiro

SEPE - Sindicato Estadual dos Profissionais da Educação

UERJ-FFP - Universidade do Estado do Rio de Janeiro - Faculdade de Formação de Professores

UERJ-FEBF - Universidade do Estado do Rio de Janeiro - Faculdade de Educação da Baixada Fluminense

UFRJ - Universidade Federal do Rio de Janeiro

UNESCO - Organização das Nações Unidas para a educação, a ciência e a cultura

UNICEF - Fundo das Nações Unidas para a Infância 


\section{LISTA DE QUADROS}

Quadro 1 - Cronologia de documentos das reformas educionais 61

Quadro 2 - Tabela de Gratificação - Programa Nova Escola........................................ 81

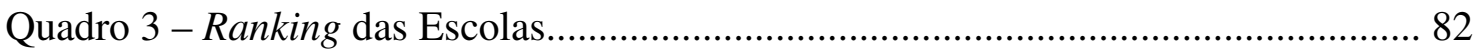

Quadro 4 - Número de alunos por modalidade de ensino da SEE - Censo Escolar 2006 93

Quadro 5 - Distribuição de temas por série 109

Quadro 6 - Sugestões de organização de eixos temáticos em Geografia conforme os $\mathrm{PCN}+$

Quadro 7 - Quadro comparativo: Reorientação Curricular - PCN+EM. 120

Quadro 8 - Reorientação Curricular - Competências e habilidades a serem desenvolvidas em Geografia 123

Quadro 9 - Reorientação Curricular / SEE-RJ - proposta de seriação. $3^{\circ}$ ano do Ensino Médio

Quadro 10 - Reorientação Curricular - proposta de seriação. $5^{\circ}$ série do Fundamental (atual $6^{\circ}$ série) 126

Quadro 11 - Parâmetros Curriculares Nacionais para o Ensino Médio - competências e habilidades a serem desenvolvidas em Geografia. 


\section{SUMÁRIO}

Introdução. 14

\section{Capítulo 1}

As Teorias Curriculares e os Currículos de Geografia .................................................. 21

1.1. Uma introdução ao estudo do currículo ............................................................... 21

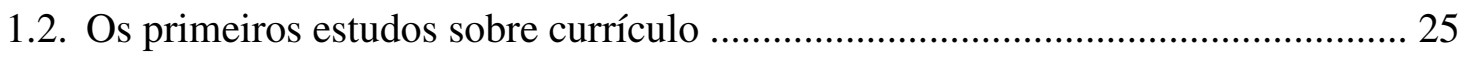

1.3. As origens das críticas aos currículos tradicionais ............................................. 26

1.4. As teorias críticas sobre o currículo ................................................................... 28

1.5. O campo se amplia, surgem as Teorias Pós-críticas ............................................. 30

1.6. O movimento de Renovação da Geografia e o entrecruzamento com o campo do

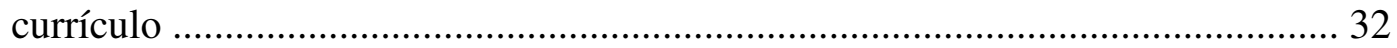

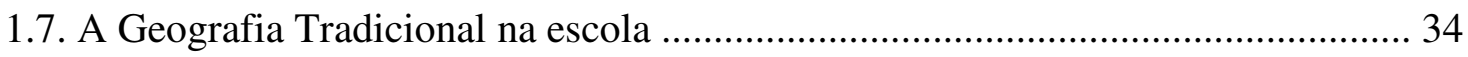

1.8. O movimento de renovação da Geografia por dentro e por fora da escola ........... 37

1.9. Currículos tradicionais e currículos críticos de Geografia: panorama da

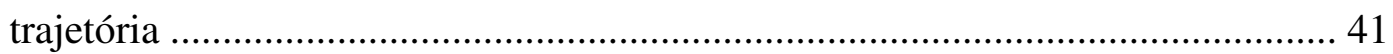

1.9.1. As transformações nos currículos de Geografia e os novos conteúdos ...... 48

1.9.2. Construtivismo, cartografia e o currículo de Geografia ........................... 52

1.9.3. Repensando os conteúdos nos currículos de geografia ............................ 54

1.9.4. Os conceitos que estruturam os novos currículos de Geografia ................. 57

\section{Capítulo 2}

Contextualizando a Reorientação Curricular por dentro das reformas neoliberais. ... 60

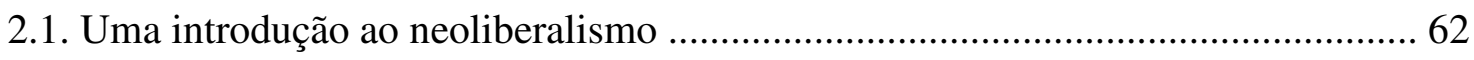

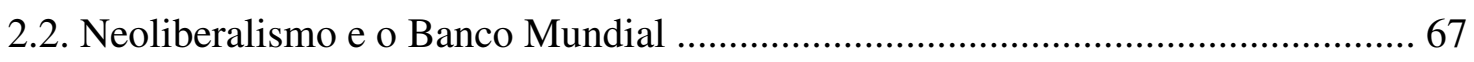

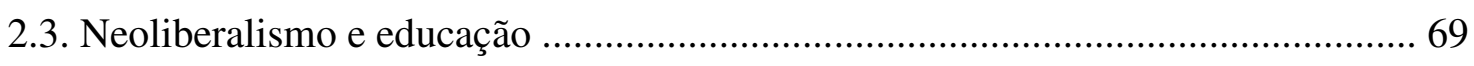

2.4. Neoliberalismo e as políticas do Banco Mundial para educação .......................... 71

2.5. As políticas de educação do Banco Mundial para o Brasil ................................... 75

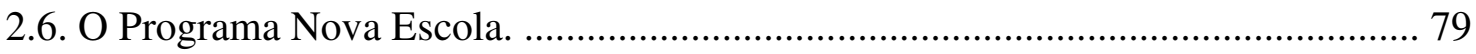

2.7. O Programa Nova Escola e a Reorientação Curricular....................................... 88 


\section{Capítulo 3}

O documento de "Reorientação Curricular" da rede estadual de ensino do Rio de Janeiro 92

3.1. Um panorama da rede estadual de ensino do Rio de Janeiro .......................... 92

3.2. Apresentando a Reorientação Curricular ........................................................ 96

3.3. Apresentando dos princípios e objetivos da Reorientação Curricular................ 97

3.4. Apresentando os princípios e objetivos da Reorientação Curricular

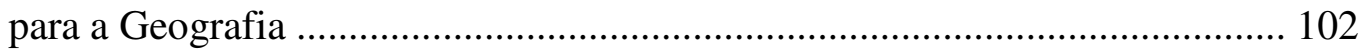

3.5. A Reorientação Curricular um contraponto com os DCNEM e os PCNs

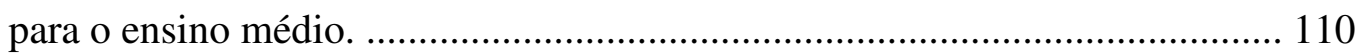

3. 6. A Reorientação Curricular - Uma análise para além dos seus os discursos .. 112

3.6.1. Uma análise da Geografia presente na Reorientação Curricular ...... 113

3.6.2. Os saberes da Geografia e as habilidades e competências ................ 122

3.6.3. A Reorientação Curricular: o "coração" de um projeto político ...... 135

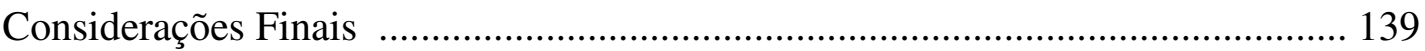

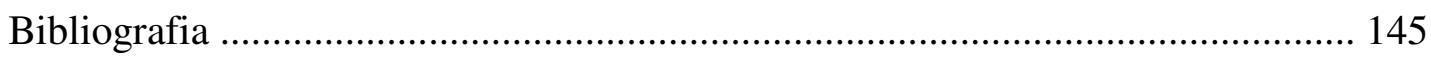

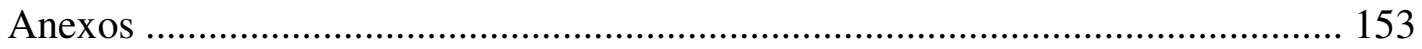

Anexo 1 - Grade Curricular de 5 a $8^{\mathrm{a}}$ série e do Ensino Médio .......................... 153

Anexo 2 - Questionário para o professor

Anexo 3 - Apresentação da Reorientação Curricular

Anexo 4 - Reorientação Curricular para Geografia 


\section{Introdução}

Esse trabalho nasceu, fruto de questionamentos em relação às políticas públicas implementadas na rede estadual de ensino do Rio de Janeiro no final dos anos de 1990, durante o governo de Anthony Garotinho e que culminou com uma reforma curricular que se iniciou no ano de 2004, durante o governo de Rosinha Garotinho, ambos de mesmo partido e com projetos políticos comuns. Tais políticas produziram tamanho estranhamento que resulta, hoje, nesse trabalho.

O início dessas transformações nesse estado ocorreu por intermédio de uma política significativa de avaliação das escolas públicas intitulada de "Programa Nova Escola" e que teve seu desenvolvimento e aperfeiçoamento ao longo da gestão dos governos Anthony Garotinho e Rosinha Garotinho. Esse processo de avaliação norteou a implantação das políticas públicas para a educação no Rio de Janeiro por oito anos, a fim de construir um novo modelo de escola e educação.

As escolas da rede pública foram avaliadas mediante critérios que refletiam índices de produtividade considerados a partir dos seguintes elementos: maior e menor evasão/permanência na escola por parte dos alunos, índices de aprovação/reprovação ao final de cada ano, melhor aproveitamento nas avaliações padronizadas e feitas pelos alunos da rede e gestões mais eficientes nas unidades escolares. O programa "Nova Escola" foi a política pública para educação que mais gerou polêmica dentre os profissionais de ensino, pais e alunos nos últimos anos no Estado do Rio de Janeiro.

No entanto, paralelamente a isto, ao longo da década de 1990, a educação brasileira também passava por transformações polêmicas durante as duas gestões do governo de Fernando Henrique Cardoso. Essas transformações pautavam-se sempre num binômio: reformas curriculares e novas avaliações para os níveis de ensino fundamental, médio e superior.

As reformas educacionais foram intensas e significativas nesse período e provocaram mudanças no campo institucional e na legislação, com destaque para criação da Lei de Diretrizes de Base da Educação (9.394/96), dos PCNs para o ensino fundamental (1997 - primeiro e segundo ciclos, 1998 - terceiro ciclo) e médio e orientações curriculares de 2004 e 2006 para o ensino médio.

A criação da nova LDBEN/96 transformava a escola de $1^{\circ}$ e $2^{\circ}$ graus em escola de ensino fundamental e médio - todo o período denominado de Educação Básica. O que parece apenas uma mudança de nome é na verdade, uma transformação de caráter 
estrutural que vai afetar a educação brasileira como um todo, sobretudo a escola pública. É neste momento que, não só o Brasil, mas em outros países da América Latina encontram-se cada vez mais atrelados às determinações de órgão representativos dos países centrais como o Banco Mundial. Essas determinações ocorrem não somente na esfera da educação, mas também nas esferas econômica e política.

Tais reformas na educação buscavam, quase sempre, desqualificar a escola que até entã0 existia no Brasil. Foi muito comum o Estado, através do Ministério da Educação, vir a público defende-las e argumentar que tais reformas seriam necessárias já que vivíamos novos tempos. Foi comum slogans como "o novo ensino médio" ou a "educação é para a vida" como se não existisse nenhuma educação que preparasse para tal objetivo. Nesses slogans buscava-se construir um novo discurso que reinventasse significados para a escola e para a sociedade.

As reformas curriculares tinham como objetivo definir novos parâmetros para a educação brasileira. Uma educação que fosse menos compartimentalizada e disciplinar e mais integrada e interdisciplinar. A construção dos Parâmetros Curriculares Nacionais para os níveis de ensino fundamental e médio tiveram como norte, contribuir com a centralidade das reformas educacionais, pois seria através deles que os sistemas de avaliação, como o Exame Nacional de Ensino Médio e os programas de avaliação dos livros didáticos se desenvolveriam.

Contudo, todas as transformações que ocorrem no mundo da educação na escala local, no Estado do Rio de Janeiro, com a implantação do programa "Nova Escola" e na escala nacional, com as reformas curriculares e os sistemas de avaliação, não estão desconectadas das transformações no mundo da produção e do trabalho em escala mundial, especialmente numa era de globalização do capitalismo e da emergência do ideário neoliberal no Mundo.

No capitalismo a crise de acumulação fordista em 1973, fomentada pela crise do petróleo, provocou nos países centrais uma grande recessão que-combinou baixas taxas de crescimento, altas taxas de inflação e levados índices de desemprego. Para combater esta crise o receituário implantado, denominado de neoliberal, buscou reduzir os gastos sociais por parte do Estado e estabilidade econômica tinha que ser paga pelos trabalhadores na redução dos salários, no aumento de impostos e na redução das conquistas sociais.

O neoliberalismo conseguiu impor esses programas de ajustes na economia capitalista dos países centrais e, posteriormente, na periferia do sistema. Na América 
Latina o ideário neoliberal chegou através de um conjunto de políticas de reajustes macroeconômico denominado de "Consenso de Washington". Em todas as partes do mundo- em que o neoliberalismo se implantou o receituário foi sempre o mesmo, profundo programa de privatizações de empresas estatais e empresas de serviços públicos-e um ataque às conquistas dos trabalhadores e dos seus sindicatos.

No Brasil de Fernando Henrique Cardoso o ideário neoliberal e a cartilha do "Consenso de Washington" foram implantados com intensidade. Um grande programa de privatizações, um projeto de redução do tamanho do Estado e uma profunda ampliação da carga tributária com vistas a pagar juros ao capital financeiro foram posta na conta da sociedade brasileira. Todo esse programa de "ajuste" tinha como objetivo reduzir os custo das empresas e atrair cada vez mais capital transnacional.

No mundo da produção e do trabalho, as novas tecnologias - com destaque para informática, microeletrônica e robótica - acarretaram novos impactos na estrutura técnica de produção e na forma de organização do trabalho humano. Uma nova divisão do trabalho requer um novo perfil de trabalhador e novas relações trabalhistas. Surgem neste momento da história do capitalismo relações de trabalho cada vez mais precarizadas e flexíveis. Os novos perfis profissionais e os modelos de formação exigidos atualmente pelo paradigma de produção capitalista são expressos, resumidamente, em dois aspectos: polivalência e flexibilidade profissionais. Trabalhadores que executem mais tarefas e tenham a capacidade de "aprender a aprender" e de um "saber fazer".

É neste contexto de transformações do mundo da educação, que no Brasil ocorrem com as reformas curriculares e a implantação dos sistemas de avaliação. No estado do Rio de Janeiro com o Programa "Nova Escola" simultaneamente às transformações impostas pelo neoliberalismo na economia brasileira, no ano de 2005, a Secretaria Estadual de Educação do Rio de Janeiro (SEE-RJ) apresentou a todas as escolas públicas da rede um documento intitulado de Reorientação Curricular cujo objetivo principal é nortear o processo de elaboração e construção do planejamento político pedagógico e do currículo das escolas da rede estadual pública.

Foram esses eventos, reformas curriculares e sistemas de avaliações com a implantação do "Programa Nova Escola" no Rio de Janeiro, associada à construção do documento de Reorientação Curricular, o ponto de partida de nossa reflexão. O presente trabalho de pesquisa acerca desse documento para Geografia se desenvolve como esforço de compreender tais eventos de ordem institucional, inseridos num 
contexto de transformações das estruturas político-econômicas de caráter neoliberal e de transformações do mundo da educação.

Nosso objetivo é fazer uma análise do documento de Reorientação Curricular como política pública com a intenção analisar as marcas da Geografia escolar inserida no documento.

Entretanto, para que tenhamos êxito, analisamos o documento que se desenvolve enquanto política pública através de diversos discursos e que possui suas origens nos contextos de transformações político-econômico do atual estágio de desenvolvimento do capitalismo.

É partindo da premissa que um documento curricular de origem governamental busca traçar políticas públicas com vista a alcançar determinados objetivos e construir mudanças em uma rede que envolve mais de 1600 escolas, essa pesquisa precisa responder a seguinte indagação. Por que a Secretaria de Educação do Estado do Rio de Janeiro, em conjunto com professores da UFRJ e do Colégio de Aplicação da mesma universidade, construíram este documento e quais as suas intencionalidades implícitas no mesmo? Afinal, uma reforma curricular expressa uma política educacional que possui intenções bem claras e definidas. Esse é um princípio norteador para responder as indagações descritas - pesquisar o programa de Reorientação Curricular como um elo, um componente central de ordem institucional, que faz parte de um projeto político que visa mudanças na rede estadual de ensino do Rio de Janeiro. Mudanças essas provocadas pelo "Programa Nova Escola" e, até que ponto esses dois programas possuem ligações com o conjunto de transformações sofridas no campo educacional no Brasil.

Não se trata de afirmar que o Estado não deva construir políticas públicas, principalmente para a educação, ou no caso do currículo, que o mesmo não deva construir uma política curricular. O que está sendo questionado neste trabalho é a forma como a Reorientação Curricular foi construída sem participação efetiva dos professores, de forma centralizada e vertical. Não se trata de um democratismo, mas de entender que um processo de construção coletiva acerca do tema, também é um espaço de formação dos profissionais envolvidos no processo educacional e que a conseqüência disto é a melhoria da qualidade da educação pública.

Outro ponto de grande relevância na pesquisa parte do princípio que as reformas curriculares trazem para o debate questionamentos significativos como: o que devemos ensinar aos alunos? Ou, por que devemos ensinar estes conhecimentos e não outros? No 
entanto, quando este debate é posto no campo da Geografia escolar a diversidade de concepções no campo desta ciência aflora, ganha novos contornos e territórios.

A Geografia brasileira, no percurso de sua trajetória desde o seu processo de institucionalização, passando pelo processo de renovação nos anos de 1980 até os dias atuais passou por transformações significativas, mudanças de caráter teóricometodológico debatidos na academia e que chegaram à escola por intermédio de novos textos, programas curriculares e livros didáticos. Nesse sentido, cabe responder a outras indagações nesta pesquisa: Quais são as marcas da seara geográfica que este currículo carrega? Qual(is) concepção(ões) teórico-metodológica(s) estão presente(s) e reificada(s) neste documento?

É por este percurso que construímos a análise do documento de Reorientação Curricular. A opção pela análise documental foi feita por entendermos que esta é uma técnica valiosa na abordagem de dados "qualitativos". Lüdke e André (1986, p.38) baseando-se nos estudos de Guba e Lincoln, afirmam que existem vantagens importantes para o uso de documentos na pesquisa educacional. Os documentos são considerados uma fonte estável e rica de pesquisa, pois persistem ao longo do tempo, podendo ser consultados quantas vezes for necessário para a obtenção de dados e que dão mais estabilidade aos resultados obtidos na investigação. É importante ressaltar que os documentos, como é o caso do documento de "Reorientação Curricular", representam uma fonte "primária" de informação, logo necessitam para uma melhor compreensão acerca do tema, estar associados a outros documentos - como os PCNs e as Diretrizes Curriculares Nacionais para o Ensino Médio.

Essa pesquisa foi divida em três capítulos. No primeiro delimitamos o tema currículo e currículo de Geografia. É neste momento, através do diálogo com vários autores do campo curricular, que buscamos a compreensão do tema para além do senso comum da sala de aula e das práticas dos professores, de que o currículo é um conjunto de conteúdos que segue determinados padrões de objetivos e metas a serem alcançadas. Nesta parte do trabalho, o debate sobre o campo foi feito com o objetivo buscar a relacionar as convergências, do ponto vista teórico-metodológico, da Geografia, acadêmica ou a escolar, com o Currículo. Esse diálogo é necessário, já que para avaliar um documento de Reorientação Curricular faz-se necessário, contextualizá-lo a luz das teorias de currículo com o objetivo refletir sobre a concepção dominante acerca do campo que o mesmo expressa. Afinal, os currículos possuem como objetivo central guiar os rumos da educação. 
No campo do currículo o diálogo foi construído com autores que debatem sobre o tema a luz da teoria social crítica com destaque para Tomaz Tadeu Silva, Gimeno Sacristán, Michael Apple e Antônio Flávio Moreira. No entanto, é com Silva (2002) que o diálogo ocorre de forma mais intensa em virtude da forma como este autor divide a trajetória do campo do currículo, muito parecido com divisão da trajetória da Geografia brasileira moderna. No campo das transformações da Geografia acadêmica e escolar as contribuições foram dadas pelos autores que travam o debate epistemológico com destaque para; Ruy Moreira, Antônio Carlos Robert de Moraes e Yves Lacoste; já sobre a Geografia escolar e os currículos de Geografia escolar as contribuições foram dadas por, Sônia Castellar, José William Vesentini, Nídia Pontuschka dentre outros. Vale destacar a contribuição de Lana Cavalcanti e Jorge Luiz Barcellos pela forma de dividir a trajetória dos currículos escolares de Geografia.

Este capítulo divide-se em dois momentos: no primeiro momento: temos um contraponto, com base nos estudos de Tomaz Tadeu Silva, entre o currículo como um campo de estudo que possui sua base de compreensão na teoria social crítica mais geral e o movimento de renovação que a Geografia percorreu ao longo dos anos de 1970 e 1980 e ainda percorre. No segundo momento, construímos um panorama sobre as transformações dos currículos de Geografia no Brasil, desde o processo de institucionalização desta ciência. Dentro desse panorama analisamos os traços que mais marcaram a trajetória da Geografia escolar brasileira. Nosso objetivo é contextualizar a Geografia impressa no documento de Reorientação Curricular da SEE-RJ na trajetória que constroem os currículos de Geografia na escola.

Para compreender as reformas educacionais propostas pelos organismos multilaterais nos países emergentes, destacando o papel do Banco Mundial, o diálogo será construído com os seguintes: Pablo Gentili, Rosa Maria Torres, Maria Clara Couto Soares, Mariano Fernández Enguita, José Luis Coraggio. Sobre o neoliberalismo como doutrina político-econômica e que intervêm nas estruturas do Estado as contribuições são dadas por Perry Anderson e David Harvey.

O segundo capítulo busca inserir a discussão curricular na lógica das políticas públicas de educação neoliberal. Entendemos que o documento de Reorientação Curricular da SEE-RJ nasce no seio de uma reforma educacional que, de forma específica, ocorre no estado do Rio de Janeiro. Essa reforma educacional intitulada de programa "Nova Escola" não se encontra isolada de um novo contexto sócio-espacial e de uma "nova" concepção de mundo. Buscamos nesse sentido, apontar quais os elos 
que unem os dois eventos, quais as suas intencionalidades, seus pontos de convergência, pois, entendemos que para comunidade escolar tais eventos - "Programa Nova Escola" e Reorientação Curricular - são de naturezas distintas.

O terceiro capítulo visa, através do estudo sobre o documento de Reorientação Curricular, retornar e dialogar com os capítulos anteriores enfocando os seguintes aspectos:

1) Descrever o documento com objetivo de apresentar suas idéias centrais e propostas para o funcionamento da rede pública de ensino e para o ensino de Geografia;

2) Analisar a sua coerência teórico-metodológica para o ensino desta ciência nos níveis fundamental e médio;

3) Entender a concepção de Geografia apresentada nos seus programas curriculares de cada série.

É neste capítulo que avaliamos o documento de Reorientação Curricular "para dentro" e "para fora". Avaliar "para dentro" é buscar no cerne da sua formulação teórico-metodológica o entendimento de Geografia, de currículo e de escola que se pretende construir. Avaliar "para fora" é buscar entender as razões e os motivos dos seus propósitos e intencionalidades.

Avaliar a Geografia dentro da Reorientação Curricular da SEE-RJ, essa é a nossa proposta. Tentamos ver o currículo para além de um simples conjunto de disciplina ou de um punhado de conteúdos a serem ministrados em sala de aula. Este é o tema e o propósito abordado e o caminho percorrido nesta dissertação. 


\section{As Teorias de Currículo e os Currículos de Geografia.}

Começamos com uma breve apresentação das idéias e concepções sobre currículo; seus significados e representações a luz de alguns autores importantes do campo como, Antônio Flávio Moreira, Gimeno Sacristán, Michael Apple, Tomaz Tadeu Silva, entre outros. Buscamos sintetizar as transformações que ocorrem no campo das teorias curriculares, usando como referencial teórico Tomaz Tadeu da Silva e Antônio Flávio Moreira buscando sempre que possível, traçar um paralelo com as transformações que a Geografia enquanto disciplina escolar e acadêmica sofre.

Toda essa abordagem acerca do campo do currículo torna-se necessário para contextualizar o documento de Reorientação Curricular a luz das teorias de currículo.

No segundo momento deste capítulo investimos no estudo a respeito das transformações que os currículos escolares de Geografia sofreram desde seu processo de institucionalização no Brasil, enfocando as correntes teórico-metodológicas que mais contribuíram para a construção desta disciplina na escola.

\subsection{Uma introdução ao estudo do currículo}

A palavra currículo no campo pedagógico possui várias definições que carregam consigo distintas concepções, que segundo Candau \& Moreira (2006), derivam de diversos modos como à educação é concebida historicamente, bem como das influências teóricas que afetam e se fazem hegemônicas em um dado momento. Sendo assim, currículo, inicialmente pode ser entendido como um arranjo sistemático de matérias, ou um elenco de disciplina e de conteúdos. Currículo é entendido também, como conjunto de estratégias para preparar o jovem para a vida adulta, ou como um conjunto de experiências trabalhadas pela escola, ou conjunto das atividades e dos meios para alcançarem os fins da educação. Nessas perspectivas, o currículo envolve a definição de objetivo e a seleção, organização e avaliação dos conteúdos escolares.

Candau \& Moreira (2006), também afirmam que diferentes fatores sócioeconômicos, políticos e culturais contribuem para que o currículo seja entendido de diversas formas. Nessa perspectiva o currículo escolar é um espaço conflitivo de interesses sociais e culturais diversos. O currículo é uma maneira de organizar uma série de práticas educativas e como construção cultural, reflete uma compreensão educativa institucionalizada e as funções sociais da escola num dado tempo histórico. 
Podemos destacar, também, alguns aspectos importantes sobre as idéias que uma parte dos professores, de maneira geral, possuem sobre a concepção de currículo:

Há professores que entendem o currículo escolar como apenas os guias curriculares, construídos pelas secretarias de educação pelo ministério da educação ou por alguma instituição de ensino; segundo, que o currículo é, apenas, um conjunto de objetivos, conteúdos e experiências de aprendizagem e avaliação; terceiro que o currículo escolar lida apenas com o conhecimento escolar e quarto que a seleção de conteúdos e procedimentos que compõe o currículo é um processo neutro e apenas científico. Porém, se procurarmos compreender o currículo como um espaço conflitivo, de interesses sociais e culturais, perceberemos que os currículos transcendem a todos esses princípios ${ }^{1}$.

Na primeira hipótese, os currículos escolares transcendem os guias curriculares porque todo documento formulado - o currículo prescrito ${ }^{2}$ - por uma secretaria de educação ou uma instituição escolar que apresenta determinados conteúdos e conhecimentos no seu processo de elaboração, quando posto em prática, nas aulas, sofre uma intervenção de forma direta ou indireta por parte dos professores e alunos. Ou seja, no dia-a-dia curricular acontecem muitas manifestações não prescritas no currículo formal que junto com as ações de docentes e discentes formam o currículo vivido ou currículo em ação ${ }^{3}$.

$\mathrm{Na}$ segunda hipótese, currículo não é, apenas, um conjunto de objetivos, conteúdos, experiências de aprendizagem e avaliação, pois esses elementos não são apenas de ordem e natureza técnicas são, também, de ordem política e cultural que estabelecem as formas como concebemos a sociedade, a escola e o conhecimento. Exemplo, quando elaboramos uma prova de caráter classificatório e competitivo temos

\footnotetext{
1 Essas proposições foram abordas e discutidas na disciplina Concepções de Currículo e Trabalho Docente ministrada pelo professor Dr. Antônio Flávio Moreira no Mestrado Acadêmico em Educação, Cultura e Comunicação, da Faculdade de Educação da Baixada Fluminense. FEBEF - UERJ, no $2^{\circ}$ semestre de 2007.

2 Segundo Sacristán (1998). Em todo sistema educativo existe algum tipo algum tipo de prescrição ou orientação do que deve ser o conteúdo, principalmente em relação à escolaridade obrigatória. São aspectos que atuam como referência na ordenação do sistema curricular, serve como ponto de partida para elaboração de materiais, controle do sistema, etc.

3 O currículo em ação segundo Sacristán (1998). É o currículo que na prática real, guiada pelos esquemas teóricos e práticos do professor. É o momento no qual o currículo se transforma em método. A prática ultrapassa os propósitos do currículo, devido ao complexo tráfico de influência e interações, que o professor sofre ao longo do processo pedagógico.
} 
em mente que a sociedade como tal, também é competitiva e estamos reproduzindo esta competitividade; ou quando criamos trabalhos em grupo podemos estar reproduzindo uma prática pedagógica que reflete uma sociedade menos competitiva e mais solidária.

Terceiro currículo escolar não lida apenas com o conhecimento escolar, mas com diferentes aspectos da cultura, pois o conhecimento é apenas uma das facetas da cultura construída e reconstruída no ambiente da escola. A ênfase dos currículos escolares tende a ocorrer na seleção dos conteúdos escolares, entretanto, esses conteúdos fazem parte de um padrão cultural. Exemplo, determinadas aulas de Geografia Regional podem dar uma enorme ênfase ao ensino de Geografia do continente europeu e da cultura européia ou uma valorização da cultura branca européia e uma subvalorização do continente africano e das culturas africanas.

Por último, a seleção de conteúdos e procedimentos que compõe o currículo é um processo político, pois no ato de selecionar e organizar os conteúdos escolares os parâmetros científicos utilizados como critério não são neutros ou desinteressados, há embutidos neles relações de poder. Os professores de Geografia quando selecionam determinados conteúdos, partilham de crenças e atitudes que foram construídos historicamente. Por exemplo, quando a cartografia ensinada e utilizada na escola ainda é uma cartografia eurocêntrica em que o meridiano de Greenwich é o meridiano de referência para contagem das horas, está aí embutida uma relação de poder, uma atitude política. Afinal quem determinou que os dias e as horas têm que ser contados à partir deste meridiano que passa pela Inglaterra? Quando e onde decidiram que seria esse o marco, porque é esse lugar?

Muitos professores de ensino fundamental e médio, da rede pública estadual de ensino do Rio de Janeiro, também, concebem as palavras currículo e programa com os mesmos significados e isto ocorre, em parte, devido à origem da palavra conforme cita Forquin.

Cabe, ainda, ressaltar que a denominação currículo expressa sentidos diferenciados no vocabulário inglês e francês, tanto em termos de riqueza semântica, quanto de usos. No léxico francês em que é restrito à categoria específica de objetos pertencentes à esfera educativa, currículo equivale a idéia de plano ou programa. Já nos países de língua inglesa, e em outros sob sua influência, abrange noções de prescrição/execução e currículo oculto/contextos culturais, dando a conotação de uma abordagem global aos fenômenos educativos.(Forquin Apud, Corrêa \& Nogueira 2002:12). 
O currículo também pode ser concebido como algo construído no cruzamento de influência e campos de atividades diferenciados e inter-relacionados conforme afirma Sacristán (1998).

Para este autor, todo sistema curricular possui níveis ou fases na objetivação do processo de desenvolvimento do significado do currículo. Sacristán afirma que o currículo pode ser visto como um objeto que cria em torno de si campos de ações diversos, onde, múltiplos agentes (Estado, Secretarias de educação professores, alunos etc.) e forças se expressão em sua configuração e nos seus objetivos. Para compreender o currículo não basta analisar apenas sua configuração estática que se apresenta num dado momento, é necessário vê-lo na sua construção interna.

Nesse sentido, o currículo encontra-se em constante movimento e percorre as seguintes fases. O currículo prescrito, que corresponde as diretrizes gerais que atuam como referência para o funcionamento do sistema curricular, ou seja, é o documento em si construído por algum órgão público ou privado para nortear uma escola ou uma rede de ensino; o currículo apresentado, que são materiais elaborados para apresentar o currículo prescrito aos professores com o intuito de clarificar e traduzir seus significados e conteúdos; o currículo modelado pelos professores, que na prática são os planejamentos anuais e os planos de aula tendo como base as diretrizes gerais do currículo e as necessidades particulares de seu alunado; currículo em ação, que é o currículo desenvolvido em aula, na prática pedagógica no dia-a-dia das aulas; o currículo realizado, que compreende os efeitos produzidos pela prática, àqueles que se realizam nos alunos e nos professores e por último o currículo avaliado, que implica o momento da avaliação, que pode ser o rendimento dos alunos ou do programa curricular em si e sua concretização.

O interessante nesta abordagem é que o currículo é visto como algo "vivo" em movimento onde todos os atores da escola (professores, alunos, pessoal de apoio) o constroem e modificam. Rocha (1994) afirma que são os processos informais e interacionais que subvertem e transformam o que é dito "legal". Os currículos não se operacionalizam de forma imperativa no dia-a-dia da sala de aula, e são interpretados de diferentes formas, distanciando-se em muito da intenção de seus criadores o que permite afirmar que os vários processos intermediários agem no sentido de transformar o prescrito, apresentado, ao final, em uma nova gama de conhecimentos considerados válidos e legítimos de cada disciplina. 
Recentes análises de estudos destacam como as preocupações dos pesquisadores têm-se deslocado das relações entre currículo e conhecimento escolar para as relações entre currículo e cultura (Candau \& Moreira, 2006). Isto ocorre porque os currículos trazem consigo, no seu interior não apenas conhecimentos, mas como esses conhecimentos são produzidos culturalmente. É por meio do currículo que certos grupos sociais, especialmente os dominantes, expressam sua visão de mundo, seu projeto social, "sua verdade".

Portanto, podemos definir também o currículo escolar como processo social constituído de lutas e conflitos, no qual diferentes concepções, ideologias e tradições entram em cena, considerando e selecionando, em determinado contexto histórico, alguns conhecimentos como socialmente válidos e, conseqüentemente, desconsiderando outros conhecimentos por não entendê-los como válidos.

\section{2. os primeiros estudos sobre currículo}

Na história do currículo brasileiro e conforme os estudos de Tomas T. da Silva (2002) o currículo aparece pela primeira vez como objeto específico de estudo e pesquisa nos Estados Unidos na década de 1920. É neste período que o processo de industrialização neste país intensifica-se resultando movimentos migratórios cada vez maiores. Passa, assim a ocorrer uma maior massificação da escolarização, com o intuito de se formar uma mão-de-obra cada vez mais qualificada. Neste momento, houve um impulso, por parte das pessoas ligadas, sobretudo à administração da educação, para racionalizar o processo de construção, desenvolvimento e testagem dos currículos. As idéias desse grupo encontram sua máxima expressão no livro de Bobbitt, The Curriculum (1918). Nesta obra, o currículo é visto como um processo de racionalização de resultados educacionais, cuidadosa e rigorosamente especificados e medido. $\mathrm{O}$ modelo institucional desta concepção de currículo é a fábrica. Sua inspiração "teórica" é a "administração científica" de Taylor - obra que passa a racionalizar o controle sobre o movimento e o tempo dos trabalhadores nas fábricas. No modelo de currículo de Bobbitt, os estudantes devem ser processados como um produto fabril. Para Silva (2002:12) "No discurso curricular de Bobbit, o currículo é a especificação precisa de objetivos, procedimentos e métodos para obtenção de resultados que possam ser precisamente mensurados". 
Bobbitt visa alcançar a eficiência burocrática na administração escolar a partir do planejamento do currículo, e o faz transferindo as técnicas do mundo dos negócios para o mundo da escola.

Ainda, segundo Silva (2002), o modelo de currículo de Bobbitt iria encontrar sua consolidação definitiva num livro de Ralph Tyler, denominado "Princípios Básicos de Currículo e Ensino" publicado em 1949. O paradigma estabelecido por Tyler iria dominar o campo do currículo nos Estados Unidos, com influência em diversos países, inclusive o Brasil. Os estudos sobre currículo tornam-se decididamente estabelecidos em torno da idéia de organização e desenvolvimento. A organização e o desenvolvimento do currículo devem responder de acordo com Tyler quatro questões básicas:

"1. Que objetivos educacionais deve a escola procurar atingir?; 2. Que experiências educacionais podem ser oferecidas que tenham probabilidade de alcançar esses propósitos 3. Como organizar eficientemente essas experiências educacionais?; 4. Como podemos ter certeza de que esses objetivos estão sendo alcançados?" As quatro perguntas de Tyler correspondem à divisão tradicional da atividade educacional: "currículo"(1), ensino e instrução"(2 e 3) e "avaliação" (4). (Tyler apud Silva, 2002:25),

Assim, a concepção do currículo é algo meramente técnico e prescritivo e isto transmite uma idéia de neutralidade cuja preocupação central encontram-se na especificação dos objetivos da educação considerados desejáveis e a definição dos conteúdos a serem transmitidos na escola para se atingirem tais objetivos. Essa tendência conservadora que dominava o campo apresentava-se, sobretudo, em possuir um caráter instrumental, apolítico e ateórico.

Essa concepção de currículo formulada por Tyler vai cristalizar-se no Brasil até os dias atuais, pois a publicação de seu livro no Brasil não é algo muito distante e é datado do ano de 1976, pouco mais de 30 anos.

\subsection{As origens das críticas aos currículos tradicionais}

Os anos da década de 1960 foram marcados por diversos movimentos de transformação de caráter social, cultural e político em diversos lugares e territórios do planeta. Neste período questões de contracultura, de liberdade sexual, a luta pelos 
reconhecimentos dos direitos das mulheres e a luta pela autonomia de diversos povos do globo entram na agenda dos movimentos sociais em diversos lugares do planeta.

Neste período, surgem também novas teorizações no campo da educação. Essas teorizações procuram questionar o pensamento e as estruturas educacionais tradicionais. Nos Estados Unidos essas novas teorizações ocorrem no chamado "Movimento de Reconceptualização"; na Inglaterra, o movimento de mesma origem é chamado de "Nova Sociologia da Educação" cujo seu principal pensador é o sociólogo inglês Michael Young. Cabe frisar que no movimento de reconceptualização americano, emergiram duas correntes: "uma procurou se fundamentar, sobretudo, no neomarxismo e na teoria crítica, sendo Michael Apple e Henry Giroux, os seus integrantes mais conhecidos no Brasil; e a outra, de tradição marcadamente humanista e hermenêutica, teve em Willian Pinar, o seu principal teórico" (Rocha 1994; 18).

Esses movimentos não ficam restritos apenas nesses dois países, na França, podemos destacar autores como Louis Althusser, Pierre Bourdieu e Jean-Claude Passeron, Baudelot e Establet e no Brasil Paulo Freire (Silva, 2002).

O Movimento de reconceptualização exprimia uma insatisfação de pessoas do campo do currículo com os parâmetros tecnocráticos estabelecidos pelos modelos tradicionais de currículo. Este movimento, na Europa, começava a perceber que a compreensão do currículo como uma atividade meramente técnica e administrativa não se enquadrava nas novas teorias sociais que ganhavam força em vários campos do conhecimento e também na pedagogia. As novas teorias que vão dar combustível a estes movimentos são a fenomenologia, a hermenêutica e o marxismo.

Já na Inglaterra, a crítica feita aos modelos curriculares tradicionais ocorreu a partir do campo da sociologia. A "antiga" sociologia da educação inglesa avaliava o fracasso das crianças mais pobres com dados puramente estatísticos, com variáveis de entrada na escola (classe social, renda, situação familiar) e com variáveis de saída (sucesso ou fracasso escolar). Analisava-se o desempenho dos alunos de forma quantitativa e não de forma qualitativa. Não havia nenhuma preocupação com o porquê do fracasso escolar das crianças, se era provocado pelos programas curriculares ou com a natureza do conhecimento na escola. É neste contexto, de crítica à antiga sociologia, que surge a Nova Sociologia da Educação (NSE) que procura fazer uma análise mais aprofundada do fracasso das crianças e adolescentes na escola inglesa. Silva destaca o papel da NSE, que: 
"buscava o desenvolvimento de uma sociologia do conhecimento que consistiria em destacar o caráter socialmente construído das formas de consciência e de conhecimento, bem como suas estreitas relações com estruturas sociais, institucionais e econômicas. A NSE, no programa traçado por Young, na introdução ao livro Knowledge and control, deveria começar por ver o conhecimento escolar e o currículo existente como invenções sociais, como o resultado de um processo envolvendo conflitos e disputas em torno das quais conhecimentos deveriam fazer parte do currículo" (Silva, 2002:67)

Em suma, os campos do currículo e da pedagogia passam por profundas transformações na Europa e nos Estados Unidos, fruto de questionamentos que essas sociedades passam através da ebulição dos movimentos sociais. Esses questionamentos que transparecem no campo do currículo vão propiciar a formação das teorias críticas de currículo.

\subsection{As teorias críticas sobre o currículo}

Os estudiosos em currículo afirmam que as teorias críticas questionam o conhecimento corporificado no currículo. Como os conhecimentos, na forma de conteúdos, foram construídos e reificados nos currículos escolares. Nesse sentido, os conteúdos são associados as relações de poder e a produção de saberes que sustentam a ordenação dos mesmos.

Para essas teorias esse conhecimento não é neutro, puro, ou epistemologicamente "correto", ele não é uma questão meramente técnica, um conjunto de conteúdos e objetivos a serem ensinados. O conhecimento presente no currículo carrega consigo uma dimensão de classe e está estreitamente relacionado as estruturas econômicas e sociais mais amplas: currículo é poder e controle social. Nesta perspectiva Silva sintetiza as teorias críticas do currículo da seguinte forma:

Com as categorias críticas aprendemos que o currículo é, definitivamente, um espaço de poder. $\mathrm{O}$ conhecimento corporificado no currículo carrega as marcas indeléveis das relações sociais de poder. O currículo é capitalista. O currículo reproduz - culturalmente - as estruturas sociais. O currículo tem um papel decisivo na reprodução da estrutura de classes da sociedade capitalista. O currículo é um aparelho ideológico do Estado capitalista. O currículo transmite a ideologia dominante. $\mathrm{O}$ currículo é em suma, um território político.

(...) 
As teorias críticas também nos ensinaram que é através da formação da consciência que o currículo também contribui para reproduzir a estrutura da sociedade capitalista. (...) A formação da consciência dominante ou dominada - é determinada pela gramática social do currículo. (Silva, 2002:147-148),

Do ponto de vista da análise marxista o currículo contribui para a reprodução das desigualdades de classe, pois nesta perspectiva há uma clara conexão entre o modo como a economia está organizada e a forma como o currículo encontra-se estruturado. Nesta vertente alguns autores contribuíram de forma significativa com destaque para Michael Apple, que discute o currículo com base nos conceitos de hegemonia e relações de poder; Henry Giroux que trata o currículo como "política cultural” e Basil Bernstein que o discute como código e reprodução cultural. No Brasil, podemos destacar Paulo Freire com o conceito de educação bancária (Silva, 2002).

Michael Apple, um dos principais autores das teorias críticas, parte dos elementos centrais do marxismo, colocando o currículo no centro das teorias educacionais e relacionando-o às estruturas mais amplas, contribuindo assim para politizá-lo. "Apple procurou construir uma perspectiva de análise crítica do currículo que incluísse as mediações, as contradições e ambigüidades do processo de reprodução cultural e social" (Silva, 2002:48).

Para Michael Apple a educação nunca é um empreendimento neutro. Pela própria natureza da instituição o educador encontra-se implicado num ato político onde não se pode separar as atividades educacionais dos inúmeros programas institucionais de tendências diversas. Apple busca compreender a escola, o ensino e o currículo relacionados às estruturas econômicas mais amplas através das articulações entre conhecimento e poder. Neste sentido afirma que as "instituições de preservação e distribuição cultural como as escolas produzem e reproduzem formas de consciência que permitem a manutenção do controle social sem que os grupos dominantes tenham que recorrer a mecanismos declarados de dominação" (Apple, 1982:12).

Ainda citando o autor, gostaríamos de dar destaque para a questão da "tradição seletiva", que segundo Apple, é um fenômeno, dentre outros, que tem orientado a estruturação do currículo.

O currículo nunca é simplesmente uma montagem neutra de conhecimentos, que de alguma forma aparece nos livros e nas salas de aula de um país. Sempre parte de uma tradição seletiva, da seleção feita por alguém, da visão que algum grupo tem do que seja conhecimento 
legítimo. Ele é pelos conflitos, tensões e compromissos culturais, políticos e econômicos que organizam e desorganizam um povo.(Apple, 2001:53)

A tradição seletiva não é neutra, desprovida de relações de poder já que "a decisão de definir o conhecimento detido por alguns grupos como o mais legítimo, como o conhecimento oficial, enquanto o de outros grupos dificilmente ver a luz do dia, revela algo extremamente importante sobre quem tem o poder na sociedade". (2001: 53). Dessa forma, determinadas disciplina escolares sobrepõe-se na escola sobre outras, no sentido de que possuem maior carga horária e maior importância sobre a sociedade. Isso explica também porque algumas disciplinas surgem por um determinado período e depois desaparecem,

Já a política cultural de Giroux fala numa "pedagogia da possibilidade" que supera as teorias de reprodução. Ele utiliza estudos da Escola de Frankfurt sobre a dinâmica cultural e a crítica da racionalidade técnica. Compreende o currículo a partir dos conceitos de emancipação e liberdade, já que vê a pedagogia e o currículo como um campo cultural de lutas.

Outro autor de destaque é Paulo Freire. Sua crítica ao currículo está sintetizada no conceito de educação bancária. Freire concebe o ato pedagógico como um ato dialógico em que educadores e educandos participam da escolha dos conteúdos e da construção do currículo. Antecipa a definição cultural sobre os estudos curriculares e inicia uma pedagogia pós-colonialista.

\subsection{O campo se amplia, surgem as Teorias Pós-críticas.}

Prosseguindo na seqüência dos estudos curriculares feitos por Tomaz Tadeu da Silva, as teorias curriculares pós-críticas tem origem nas abordagens pós-moderna e pós-estruturalista que ganham força no campo da pedagogia já nos anos 1980. Essas teorias levam em conta a multiplicidade e diversidade de culturas na formulação das propostas curriculares na escola, (o multiculturalismo) o papel do gênero e a pedagogia feminista que introduz novas questões na reprodução das desigualdades sociais; as questões de raça, etnia, cultura e sexualidade na produção das diferenças e desigualdades para além das questões de classe social. Assim, para Silva (2002:149), as teorias curriculares pós-críticas podem ser sintetizadas da seguinte forma. 
"As teorias pós-críticas ampliam e, ao mesmo tempo, modificam aquilo que as teorias críticas nos ensinaram. As teorias críticas continuam a enfatizar que o currículo não pode ser compreendido sem uma análise das relações de poder nas quais ele está envolvido. Nas teorias póscríticas, entretanto o poder torna-se descentrado. $\mathrm{O}$ poder não tem mais um único centro, como o Estado, por exemplo. O poder está espalhado por toda a rede social. As teorias pós-críticas desconfiam de qualquer postulação que tenha como pressuposto uma situação finalmente livre de poder. Para as teorias pós-críticas o poder transforma-se, mas não desaparece. Nas teorias pós-críticas o conhecimento não é exterior ao poder, o conhecimento não se opõe ao poder. $\mathrm{O}$ conhecimento não é aquilo que põe em cheque o poder o conhecimento é parte inerente do poder. Em contraste com as teorias críticas, as teorias pós-críticas, não limitam a análise do poder ao campo das relações econômicas do capitalismo. Com as teorias pós-críticas, o mapa do poder é ampliado para incluir os processos de dominação centrados na raça, na etnia, no gênero e na sexualidade.

As teorias pós-críticas continuam enfatizando o papel formativo do currículo. Diferentemente das teorias críticas, entretanto, as teorias póscríticas rejeitam uma hipótese de uma consciência coerente, centrada, unitária. As teorias pós-críticas rejeitam, na verdade a própria noção de consciência, com suas conotações racionalistas e cartesianas".

Silva (2002:146) chama atenção para as teorias pós-modernas e pósestruturalistas, para os estudos culturais e os estudos pós-coloniais, além do chamado multiculturalismo na formulação de currículos com uma perspectiva pós-crítica. Para ele, as teorias pós-críticas não são teorias da superação da análise crítica, as teorias póscríticas vão expandir a compreensão dos processos de dominação e de poder para além das questões de classe social, e nesse sentido ele afirma que "as teorias de pós-críticas podem nos ter ensinado que o poder está em toda parte e que é multiforme. As teorias críticas não nos deixam esquecer, entretanto, que algumas formas de poder são visivelmente mais perigosas e ameaçadoras do que outras" (Silva, 2002:146).

As teorias pós-críticas ampliam a nossa compreensão de currículo, após o conhecimento das teorias críticas e pós-críticas, torna-se impossível conceber o currículo de forma ingênua e desvinculada das relações sociais de poder. Para as teorias críticas isso significa nunca esquecer, por exemplo, a determinação econômica e a busca da liberdade e emancipação; e para as pós-críticas significa questionar e ou ampliar muito daquilo que a modernidade nos legou. 
Vejamos agora, como este movimento de renovação, no qual as teorias curriculares passam, possui similaridades com o movimento de renovação em que a Geografia brasileira sofre ao longo das últimas décadas.

\subsection{O movimento de Renovação da Geografia e o entrecruzamento com o campo do currículo.}

É fato que a Geografia universitária e escolar, ao longo dos últimos 40 anos, passou por profundas transformações de caráter teórico-metodológico-epistemológico, no Brasil e em vários outros países, principalmente na Inglaterra, França e Estados Unidos, e este processo se deu por rupturas, transformações e hibridismos ${ }^{4}$. No Brasil, grande parte das transformações que ocorreram na ciência geográfica, de alguma forma, chega à geografia escolar,trazendo novas perspectivas para o ensino desta disciplina.

Essas transformações que ocorreram na geografia acadêmica e escolar e no campo do currículo possuem similaridades. De forma mais geral, é possível traçar um paralelo das mudanças ocorridas no campo do currículo e no campo da geografia em determinados contextos históricos.

Em seu livro Documentos de Identidade, Tomaz Tadeu Silva (2002) classifica as teorias curriculares em tradicionais, críticas e pós-críticas. Como já dito anteriormente, para este autor as teorias críticas são àquelas de contestação e insatisfação as teorias curriculares tradicionais que se encontram fundamentadas no tecnicismo, no pragmatismo e empirismo. As teorias críticas de currículo são aquelas ligadas à teoria social crítica mais ampla que chega à pedagogia, fundamentadas em grande parte, pelas teorias marxistas e pela fenomenologia. De certo modo a Geografia Crítica no Brasil também surge contestando a Geografia Tradicional positivista e a Geografia Nova de fundamentação teórica neopositivista. Em comum - teorização crítica do currículo e Geografia Crítica, apresentam uma contestação de cunho social, ambas são reflexos dos movimentos sociais de caráter classista, de liberdade e emancipação, que vão emergir

\footnotetext{
${ }^{4}$ Para melhor conceber o conceito de híbrido partiremos das idéias de Lopes (Apud García Canclini, 2008) quando esta diz que "a hibridização refere-se aos fenômenos difusos da cultura em virtude de o mundo torna-se cada vez mais complexo e fragmentado. Pelos processos de hibridização os discursos perdem suas marcas suas marcas originais: são rompidas coleções organizadas pelos sistemas culturais e novas coleções são formadas, os processos simbólicos são desterritorializados e os gêneros impuros se expandem”. A hibridização, tudo o que é híbrido, pressupõe uma mistura de discursos e a tradução destes num novo contexto através de uma nova forma.
} 
nos anos de 1960 pela Europa e Estados Unidos e no Brasil nos anos de 1970, junto com o movimento de redemocratização do país e pelo fim da ditadura militar.

Se as teorias curriculares críticas têm suas obras marcantes, que vão consolidar o movimento de renovação no pensamento curricular, como o livro Ideologia e Currículo, de Michael Apple, publicado pela primeira vez nos Estados Unidos em 1979, o movimento de renovação na Geografia também tem obras importantes de referência com a que vão inaugurar e consolidar o movimento de renovação da Geografia como o livro do marroquino francês Yves Lacoste (1993), A Geografia - Isso Serve em Primeiro Lugar Para Fazer a Guerra, título da edição portuguesa publicado em 1977 e que chega ao Brasil no mesmo ano, e Marxismo e Geografia do italiano Massimo Quaini. Ou ainda, Por uma Geografia Nova: da crítica da Geografia a uma Geografia crítica, de Milton Santos, um de nossos maiores geógrafos, e que se encontrava no exílio, retornando ao Brasil em 1978. Cabe ressaltar que essas obras possuem em comum a descoberta da ideologia, da epistemologia e do marxismo. Todas as três são resultantes das transformações em que passam a teoria social crítica no período que chegam no campo da pedagogia e no campo da Geografia.

Na obra de Lacoste, - A Geografia - Isso Serve em Primeiro Lugar Para Fazer a Guerra - o autor faz um estudo sobre a Geografia ensinada nas escolas. Comenta sobre a forma de ensinar essa disciplina que é "enfadonha", desinteressante, pois não visava a ser crítica, ausente com as experiências de vida dos alunos, porém que servia intensamente aos interesses ideológicos do Estado e das classes sociais hegemônicas. Portanto, para ele, existem duas geografias: a Geografia dos professores que tinha como objetivo ideológico dar aos alunos "consciência patriótica" e uma outra Geografia dos "Estados Maiores" que via na produção e organização dos espaços, relações de poder e controle.

Na Obra de Milton Santos a noção da historicidade do espaço é introduzida na Geografia e o conceito de espaço geográfico ganha nova forma. A sociedade é o seu espaço geográfico e o espaço geográfico é a sua sociedade. Santos insere a Geografia no debate intelectual maior, debates políticos e filosóficos, que naquele momento agitavam o mundo das idéias. Já na Obra de Massimo Quaini, Marxismo e Geografia, o autor busca elucidar a essência do conteúdo do espaço geográfico na dialética da historicidade da natureza (Moreira, 2007).

Cabe aqui, também uma comparação, guardando as devidas proporções e magnitudes, com o Encontro Nacional de Geógrafos organizado pela AGB em 1978 na 
cidade de Fortaleza, com o movimento de reconceptualização com a I Conferência sobre Currículo, na Universidade de Rochester, Nova York, em 1973. O primeiro movimento exprimia uma insatisfação com a geografia tradicional e quantitativa, sua filiação com a manutenção do poder e com a ditadura militar. Já o segundo movimento, expremia uma insatisafação com as teorias tradicionais de currículo, que viam o campo como uma atividade meramente técnica e administrativa mas que tinha manutenção com o poder.

De uma forma mais geral, podemos salientar que existe também, em comparação com as teorias curriculares, uma "Geografia Tradicional" e uma "Geografia Crítica" cujas suas bases teóricas encontram-se, de forma simplificada, norteadas, respectivamente no positivismo/empiricismo e marxismo/dialética. Porém, não podemos afirmar que existe uma teoria pós-crítica da Geografia, assim como existem as teorias pós-críticas de currículo baseadas no pós-modernismo e no pós-estruturalismo. Podemos sim afirmar que existe uma Geografia que nos anos da década de 1980 e principalmente ao longo da década de 1990 vai "beber" das mesmas fontes teóricas.

\subsection{A Geografia Tradicional na escola}

Do início do processo de institucionalização ${ }^{5}$ da Geografia como ciência no Brasil nos anos de 1930 até o final dos anos 1970 e início dos anos 1980, a Geografia ensinada nas escolas, de forma mais geral, era tida como uma Geografia Tradicional de caráter positivista e empiricista. É preciso deixar claro, entretanto, que esta Geografia ainda é muito presente nas escolas, nos programas e nos materiais didáticos e que muitos professores de Geografia ainda trabalham nesta perspectiva.

Identificamos a Geografia Tradicional com aquele que possui seus fundamentos teóricos no positivismo, uma geografia que se diz neutra do ponto de vista científico e sem ideologia. Muitos professores a identificam, tão somente, como um discurso geográfico mnemônico, que procura descrever os fenômenos existentes na paisagem não explicando-os. Antônio Carlos Robert de Moraes (apud Resende, 1986: 25), em

\footnotetext{
${ }^{5}$ O período da institucionalização da geografia no Brasil se revela altamente interessante. A armação de um aparato institucional dedicado a essa disciplina data da década de 1930 com a organização dos cursos universitários de Geografia em São Paulo (1934) e no Rio de Janeiro (1935), a normalização da disciplina no na escola básica de alguns Estados, a fundação da Associação dos Geógrafos Brasileiros (1934), a criação, pelo Estado, do Conselho Nacional de Geografia (1937) e do Instituto Brasileiro de Geografia e Estatística (1939). É correto afirmar que a criação dessas instituições se coloca como estratégia utilizada na busca da cientificidade, da legitimidade e da inserção da profissão na modernidade.
} 
seu livro Pequena História Crítica, publicado pela primeira vez, em 1981, a define da seguinte maneira.

"ciência empirista, que recusa-se a transcender o dado em si, o imediato, para não correr o risco de surpreender um sentido que a questione em seu fundamento mesmo. "ciência que assenta sua análise - ou por outra: constitui o seu objeto - "no solo e não na sociedade" que produz e reproduz este solo, vale dizer disciplina igualmente naturalista, para que a História não existe, mas somente o tempo geológico supra-humano e diante do qual a sociedade e seu tempo parecem pequeninos, irrelevantes $(\ldots)$ "

De certa maneira, podemos dizer que essa Geografia predominou na escola brasileira até o início dos anos de 1980 quando começa a perder campo para uma outra Geografia - a chamada Geografia Crítica $^{6}$ - que surge na escola e nos meios acadêmicos brasileiros durante a década de 1970 .

A geografia tradicional na escola sempre foi marcada pelo padrão naturezahomem-economia, (N-H-E) ${ }^{7}$ na qual todo o ensino de Geografia, irremediavelmente, inicia-se pelos estudos da natureza e, nos livros didáticos, os primeiros capítulos são os de relevo, clima, vegetação, hidrografia. Posteriormente surgem os capítulos de geografia da população arrumados sempre na seguinte ordem: formação da população (raças e etnias), crescimento da população (natalidade x mortalidade), estrutura da população (idade, sexo e atividades econômicas) e dinâmica da população (migrações); e na seqüência seguem os estudos da economia (indústria, agrária e urbano e rural). Quando os livros didáticos e programas não estão arrumados desta forma o que vemos de diferente é uma arrumação do tipo H-E-N o que não altera em nada, pois a forma de compreender a realidade (ou se é que isto é possível?) é sempre fragmentada, pois o mundo é visto pela Geografia por "partes" onde a totalidade é a soma das "partes", o que é inerente ao positivismo.

\footnotetext{
${ }^{6}$ Sobre a discussão da chamada geografia crítica pelo menos, duas concepções teóricas são divergentes. Para Vesentini a "Geografia Crítica" ou Geocrítica no Brasil nasce, fundamentalmente, nas escolas de ensino fundamental e médio e nos pouquíssimos cursinhos vestibulares. Para este autor, a geocrítica no Brasil, se iniciou como um esforço por parte de alguns docentes de superar a sua tradição, as sua formação universitária, aquilo que as universidades diziam que "deveria ser ensinado". Para Douglas Santos a "Geografia Crítica" virou uma marca e não uma discussão.

${ }^{7}$ Ver MOREIRA, Ruy. O Discurso do Avesso (para a crítica da Geografia que se ensina). Dois Pontos: Rio de Janeiro, 1987.
} 
O resultado desta forma de ver o mundo e de se ensinar Geografia é que esta disciplina sempre foi vista na escola, por pais e alunos, como uma disciplina sem "lógica" descontextualizada do mundo vivido dos educandos, enciclopédica e mnemônica, onde o que mais vale é ter boa memória para decorar fatos e acontecimentos.

Márcia Spyer Resende em sua obra A Geografia do Aluno Trabalhador, publicada em meados dos anos 1980 faz severa crítica ao ensino de Geografia Tradicional.

"Porque não basta justapor as partes [resultantes da descrição de aspectos do objeto] para se obter a totalidade do objeto. Não basta descrever exaustivamente e depois somar relevo + clima + vegetação + economia + população para se lograr um espaço geográfico integrado. A totalidade não é uma soma, ele é uma síntese. E esta síntese só, pode ser alcançada através de um elemento mediador que permeie cada uma das partes através de uma categoria interpretativa que permita estabelecer a lógica deste espaço. Esta categoria só pode ser o trabalho social concreto, com todas as suas determinações históricas [no Brasil de hoje, o modo de produção capitalista, garantido e administrado pelo estado burguês]. Sem ela, não há integração possível do objeto espaço. Sem ela, o que há no máximo é a tentativa de soldar canhestramente as suas várias dimensões atomizadas desde o início e em definitivo pela análise, através de alguns raros exemplos de interdependência..." (1986: 31).

Percebe-se nesta autora uma profunda crítica à Geografia Tradicional, e esta crítica é sustentada por bases teóricas e metodológicas de cunho marxista, onde a categoria trabalho social na formação do objeto de estudo da Geografia - o espaço geográfico -, ganha maior destaque, ressaltando ainda, que ao contrário da Geografia Tradicional o espaço geográfico é um produto da sociedade e, portanto, histórico.

Essa crítica à Geografia Tradicional com base no marxismo vai alterar de forma bastante significativa, os conteúdos geográficos nos currículos, programas e livros didáticos de Geografia a partir dos anos de 1980. Um bom exemplo de como isto ocorre é a coleção de livros didáticos de $5^{\mathrm{a}}$ à $8^{\mathrm{a}}$ série do antigo primeiro grau dos professores William Vesentini e Vânia Vlach - batizada de Geografia Crítica - nome apropriado do próprio movimento de renovação da Geografia brasileira. 


\subsection{O movimento de renovação da Geografia por dentro e por fora da escola.}

O grande marco da renovação da Geografia brasileira para muitos autores, foi sem sombra de dúvidas o $3^{\circ}$ Encontro Nacional de Geógrafos promovido pela AGB em 1978, na cidade de Fortaleza. Isto não quer dizer que a geografia brasileira renova-se a partir desta data e deste evento. $\mathrm{Na}$ verdade, este encontro foi um marco da renovação que a Geografia vinha sofrendo ao longo desta década dentro do Brasil. Entretanto, esta renovação na ciência geográfica não está descolada do movimento que a sociedade brasileira e mundial sofreu ao longo das décadas de 1960 e 1970. O movimento de renovação da Geografia é fruto dos movimentos sociais deste período, movimentos de contestação políticos e culturais. Cabe ressaltar que no Brasil vivíamos em pleno período de ditadura militar, e as lutas por uma democratização do país intensificavam-se dia-a-dia.

O episódio do $3^{\circ}$ Encontro Nacional de Geógrafos vem expressar todo esse processo que, de certa forma, já vinha tomando corpo na sociedade brasileira - a busca pela garantia dos direitos democráticos. $\mathrm{O} 3^{\circ} \mathrm{ENG}$ foi rigorosamente um encontro. Não apenas no sentido formal dos profissionais de Geografia, mas um encontro de experiências que vinham se desenvolvendo em todo o Brasil, em diferentes lugares, por diferentes pessoas, dentro de uma perspectiva crítica. Um encontro que acontece num momento onde a sociedade brasileira passava por grandes transformações, com o reaparecimento de importantes agentes sociais, como o movimento operário e o movimento estudantil.

Moreira (2007) ao falar sobre o movimento de renovação, reafirma o $3^{\circ}$ ENG como um marco da renovação geografia brasileira e, nos primeiros anos, antes do encontro, e os primeiros anos posteriores ao encontro a idéia de "geografia crítica", ou o nome "geografia crítica ainda" não era ventilado. O autor, ainda distingue os dois momentos: o primeiro se identificava como fase da crítica, período em que e o segundo como fase oficialidade crítica. (Moreira, 2007: 36).

Duas fases distinguem-se no movimento de renovação. A primeira situase no período imediatamente anterior e posterior ao $3^{\circ} \mathrm{ENG}$, reunindo os anos de virada das décadas de 1970-80. è a fase das mudanças mais efetivas, fase da crítica que indaga sobre o sentido e significado do discurso geográfico ("O que é, para que serve, e para quem serve a geografia?, renovando onde era possível. A segunda situa-se a partir da metade da década de 1980. É a fase onde a renovação vira uma 
oficialidade (uma "geografia crítica"), muda o ritmo e o sentido de rumo e assim consome sua primazia e se consome nessa mudança. A primeira fase é um movimento que redescobre a geografia. A segunda, que leva a opacificar-se.

Já William Vesentini (2001), reafirma o movimento de renovação como movimento de contestação político da época, um movimento que nasce e possui sua origem nos movimentos sociais, ou seja, um movimento quem é para além das formulações teóricas universitárias.

"A geografia crítica, enfim, foi aquela - ou, mais propriamente, aquelas, no plural - que não apenas procurou superar tanto a geografia tradicional quanto a quantitativa, como principalmente procurou se envolver com novos sujeitos, buscou se identificar com a sociedade civil, tentou se dissociar do Estado (esse sujeito privilegiado naquelas duas modalidades anteriores de geografia!) e se engajar enquanto saber crítico - aquele que analisa, compreende, aponta as contradições e os limites, busca contribuir na ação... - nas reivindicações dos oprimidos, das mulheres, dos indígenas, dos negros e de todas as demais etnias subjugadas, dos excluídos, dos dominados, dos que ensejam criar algo novo, dos cidadãos em geral na (re)invenção de novos direitos".

Para este autor o movimento de renovação da Geografia é fruto das contradições que surgem na sociedade brasileira com anos de repressão feitos pela ditadura militar e pela ausência de democracia. São os movimentos de transformação que vêm da sociedade brasileira e mundial que empurram o movimento de renovação da Geografia.

Moraes (1982), também entende este movimento de renovação como algo diverso constituído de inúmeras correntes de pensamento

"A Geografia Crítica. Esta apresenta um mosaico variado de posições e propostas: desde um niilismo radical que vive apenas da destruição da velha Geografia (o que na prática implica em sua liquidação), até a postura humanista da Geografia de denúncia (que muitas vezes não rompe com os procedimentos de análise da Geografia tradicional, mudando apenas o temário). De todo o modo, a unidade da geografia Crítica manifesta-se na perspectiva de oposição a uma realidade social e espacial contraditória e injusta, fazendo do conhecimento geográfico uma arma de combate à situação instituída. Esta unidade de propósitos dada em última instância pelo posicionamento político (englobando desde posições liberais até posições marxistas), não anula a diversidade interna no que se refere aos posicionamentos metodológicos" (Moraes, 1982:42). 
Entretanto, como todo movimento de renovação, constituído em uma determinada época, há sempre uma corrente teórica que se torna hegemônica e que, posteriormente da identidade ao movimento e esta corrente na Geografia foi, sem sombra de dúvida, o marxismo e isto se percebe claramente nas palavras de Moraes.

"Um dos desdobramentos do processo de renovação da Geografia, foi a aproximação de parte dos geógrafos aos fundamentos do materialismo dialético. Assim, iniciaram-se tentativas de analisar questões geográficas a luz deste método" (Moraes,1982:43)

Moreira (2007), também coloca que as temáticas do marxismo e da renovação da Geografia se entrecruzam neste período e que os geógrafos “descobrem” Marx como base filosófica e político-ideológica da renovação. Afirma que a geografia "nasce tatibitateando a linguagem marxista de Lefebvre, Althusser, Gramsci e Lukács, este último trazido por Amando Correa da Silva em suas reflexões sobre a ontologia marxista" (Moreira, 2007: 29). Contudo, Ruy Moreira é incisivo ao dizer que a vertente marxista não é a única, porém, é a vertente hegemônica e com muita propriedade cita as outras vertentes que deram pluralidade ao movimento de renovação.

Prova tal caráter de um movimento múltiplo a bibliografia múltipla que parece junto à renovação. Um exemplo é o Espaço e ciências humanas, de Tonino Bettanini, um livro de claro matiz fenomenológico, publicado pela Editora paz e Terra, a mesma dos livros de Quaini. E, ainda, Perspectivas da geografia, um coletânea organizada por Christofolleti, apontando para matrizes marxistas (Peet, Santos, Harvey, Soja), fenomenológicas (Tuan, Buttimer, Lowenthal, Guelke, Relph) e positivistas (Christofolleti, Pred). O próprio Lacoste a Rigor não é marxista (Moreira, 2007: 29).

É importante perceber que a trajetória do movimento de renovação da Geografia possui inúmeras "geografias críticas", que possui sua base de pensamento na teoria social crítica e nos movimentos sociais que vão dar combustível ao movimento como um todo. Entretanto, é importante perceber que as obras que vão dar sustentabilidade teórica ao movimento de renovação da geografia são de origem marxista ou possui alguma similaridade com o marxismo. 
Nesse sentido, faço uma reflexão com a qual coaduno com as idéias de Michael Apple, exposto anteriormente, que o currículo nunca é simplesmente uma montagem neutra de conhecimentos. Sempre parte de uma tradição seletiva, da seleção feita por alguém (ou alguns), da visão que algum grupo (grupos) tem do que seja o conhecimento legítimo.

O currículo e o conhecimento são feitos por conflitos, tensões e compromissos culturais, políticos e econômicos que organizam e desorganizam um povo e neste momento, a Geografia brasileira passa por uma profunda transformação porque a sociedade civil também passa, é o momento da redemocratização do país e a AGB e o Encontro de Geógrafos de Fortaleza torna-se palco deste conflito onde diversos grupos de militância distinta vão buscar construir uma hegemonia político-científica. O desdobramento deste conflito, de certa forma vai aparecer na geografia escolar.

A chamada Geografia Crítica na escola não consegue alterar, em grande parte, a forma como a própria disciplina se estrutura nos currículos, programas e livros didáticos. A Geografia escolar permanece estruturada no padrão N-H-E. Entretanto, esta Geografia passa questionar, profundamente seus fundamentos positivistas que de forma impiedosa fragmenta a totalidade social, e compartimentaliza excessivamente os elementos que compõe o espaço. A Geografia Crítica passa a questionar a Geografia Tradicional que apenas transfere ao aluno um punhado de informações atomizadas sobre o mundo físico, econômico e humano, e passa a propor que se investigue e pesquise o espaço como um todo integrado, em que o econômico o físico e o humano sejam estudados em sua dimensão social e histórica.

A Geografia Crítica escolar passa a considerar o homem como sujeito e não como um objeto do processo histórico, propõe que não separe a sociedade da natureza, para que não se perca a dimensão de totalidade. Propõe que se ensine uma Geografia aos alunos que sirva aos seus interesses e não aos interesses de que detêm o poder. Assim, concordamos com Resende (1986:40), quando afirma que "a Geografia Crítica escolar passa a propor, na sua ação pedagógica que o espaço geográfico à ser ensinado tenha como referência o Espaço vivido ${ }^{8}$ ou Espaço Real cujo as raízes estão deitadas na divisão social do trabalho e, conseqüentemente, nas relações sociais de produção"

\footnotetext{
${ }^{8}$ Segundo Resende (1986) o "espaço real" ou "espaço vivido" é aquele espaço cujo a lógica os alunos experimentam na própria carne, espaço que faz parte de suas histórias, das múltiplas atividades que "enchem" sua vidas.
} 
Sintetizando este momento, as transformações sociais políticas e econômicas que davam o Brasil na década de 1980 resultaram no fortalecimento dos movimentos sociais, do sindicalismo, dos partidos de esquerda, das lutas dos povos que durante mais de vinte anos de ditadura sofreram com a marginalização, fruto da concentração da

renda e da terra. É um momento de grandes questionamentos por parte da sociedade civil sobre as formas de poder exercidas e que vão refletir na escola, nos currículos e na Geografia ensinada. Afinal construir uma democracia seja ela popular ou liberal, pressupõe novos pilares.

A ciência geográfica, assim como os estudos sobre o currículo possuem similaridades, áreas de contato e convergência e isto ocorre porque refletem a dinâmica da sociedade. As teorias críticas do currículo e a Geografia Crítica negam a premissa de neutralidade e afirmam os conceitos de ideologia e poder. As Teorias críticas do currículo são teorias da desconfiança, questionamento e transformação radical e o mesmo pode-se afirmar da Geografia Crítica que radicaliza na forma de se estudar a sociedade.

As teorias críticas de currículo vão trazer a tona o papel da ideologia nas questões educacionais, e isso também ocorre na Geografia Crítica, que vai denunciar a Geografia Tradicional quanto ao seu papel ideológico que fragmenta a totalidade social.

De alguma maneira, nós, professores de Geografia, incorporamos em nossas práticas pedagógicas, em nossos conteúdos e currículos escolares, boa parte das transformações que ocorrem em nossa ciência e na pedagogia e vamos assim, construindo nossa identidade na escola. Nossa identidade é constituída de múltiplas determinações, hibridismos, pois de forma constante, incorporamos os movimentos de transformação da sociedade, de mudanças de paradigmas, pois como afirma Tomaz Tadeu, o currículo é trajetória, viagem, percurso.

\subsection{Currículos tradicionais e currículos críticos de Geografia: panorama da trajetória.}

Nessa trajetória que a Geografia percorre, no Brasil, desde a sua institucionalização ${ }^{9}$ como ciência até a atual década, nós, os professores, de alguma

9 A Geografia é uma disciplina que primeiro surge no ensino secundário e posteriormente institucionaliza-se no meio acadêmico. Esse fenômeno ocorre no Brasil e em outros países do mundo. Rocha (1996) afirma que a Geografia surge no Brasil, como disciplina escolar autônoma a partir da 
forma, vamos incorporando em nossas práticas pedagógicas as transformações de caráter epistemológico e teórico-metodológico dos currículos. Com isso vamos criando uma tradição desta ciência nas escolas, que são representadas pelos saberes e conteúdos desta disciplina.

A disciplina escolar Geografia mantém vínculos com a respectiva ciência por meio dos conceitos, métodos e teorias geográficas. Os conteúdos disciplinares são organizados a fim de atender as concepções hegemônicas da própria ciência e correspondem a um tempo espaço específicos, articulados as concepções pedagógicas de organização do currículo e organização do ensino. (Cacete, Paganelli, Pontuschka, 2007: 113).

Desta forma, a disciplina escolar geografia é fruto do movimento da ciência geográfica articulado com as transformações que ocorrem no ambiente escolar e que atende por concepções hegemônicas de determinados grupos com interesses diversos em períodos específicos.

Podemos agrupar estas transformações dos currículos escolares de Geografia sofreram, após a sua institucionalização no Brasil, em três grandes momentos. O primeiro momento, o da Geografia Tradicional de caráter positivista e funcionalista, seria o mais longo e duradouro que teria seu início na década de 1930 e estender-se-ia até meados da década de 1970. Este período, por ser o mais duradouro, talvez, tenha impresso em nossos currículos escolares conteúdos que reificaram grande parte de nossa "tradição geográfica" ${ }^{10 "}$.

criação do colégio Pedro II, em 1837. De acordo com o decreto do dia 02 de dezembro de 1837, como consta no Artigo 3. Neste colégio, serão ensinadas as línguas latina, grega, francesa, e inglesa, retórica e os princípios elementares de geografia, história, filososfia, mineralogia, álgebra, geometria e astronomia.

A Geografia, no Antigo Ginásio, até a época da fundação da FFCL/USP, em 1934, nada mais era do que a dos livros didáticos escritos por não Geógrafos. Esses expressavam geralmente o que foi a ciência até meados do século XIX, na Europa: enumeração de nomes de rios, serras, montanhas, ilhas, cabos, capitais, cidades etc. A memória era a capacidade principal para o estudante sair-se bem nas provas.

Foram importantes para a produção Geográfica, até 1934, as pesquisas feitas pela Comissão Geográfica e Geológica do Estado de São Paulo, existente desde 1886. Esse período era chamado de a "pré-história da Geografia" no País, porque não eram formados academicamente na área os primeiros pesquisadores de aspectos ligados ao espaço que serviram de referência para a geração inaugural de geógrafos brasileiros. (Cacete, Paganelli, Pontuschka; 2007: 113).

10 Utilizo o conceito de "tradição geográfica" fazendo um contraponto com o conceito de tradição seletiva de Michael Apple. A "tradição geográfica" é resultante das concepções hegemônicas que determinados grupos ou escolas reificaram na Geografia brasileira que, de certa forma, apresentam suas marcas em nossos currículos escolares. 
O segundo momento seria aquele que constituíra um período de ruptura com o primeiro na questão teórico-metodológica e epistemológica, e estender-se-ia ao longo dos anos de 1980 até a metade dos anos de 1990. A principal marca deste período teria reflexo na construção de novos conteúdos que seriam acrescentados aos currículos, fruto do debate travado com o marxismo.

E um terceiro momento que não teria um caráter de ruptura com o segundo, mas pelo contrário, seria um aprofundamento do período que o precede, e os geógrafos, principalmente aqueles mais ligados ao ensino, vão buscar nas formulações dos novos currículos escolares um diálogo cada vez maior e, cada vez mais intenso com a pedagogia, as teorias curriculares e o socioconstrutivismo.

É precioso deixar claro, por um lado, que no interior de cada período, há movimentos, contra-hegemônicos de cada corrente teórico-metodológica, mas que de certa forma sempre há grupos que se tornam hegemônicos e que acabam por influenciar de forma mais significativa o pensamento da época. O currículo, portanto, não será usualmente unitário, mas ele próprio corporificará tendências contraditórias. E isso vai ocorrer com a Geografia em cada momento. Em cada período de maior domínio teóricometodológico de um pensamento hegemônico, incorporaremos saberes produzidos por movimentos contra-hegemônicos.

Por outro lado, também podemos considerar que hoje convivemos com a influência dos três momentos (simultaneidade de diferentes tempos), embora possamos distinguir como vimos à hegemonia de algumas tendências.

De alguma maneira podemos sintetizar que na visão tradicional de ensino de Geografia o professor exige do aluno apenas a reprodução do conteúdo prescrito. "Essa Geografia, como já fora exposto anteriormente, se caracteriza pela estruturação mecânica dos fatos, fenômenos e acontecimentos divididos em aspectos físicos, aspectos humanos e aspectos econômicos, de modo a fornecer aos alunos uma descrição das áreas estudadas, seja de um país, de uma região ou de um continente" (Cavalcanti; 1998: 20). Assim, os programas e currículos ${ }^{11}$ desta ciência, na perspectiva tradicional, apresentam-se na forma de listas de conteúdos onde o objetivo de cada conteúdo é aprender o próprio conteúdo e todo o saber encontra-se centrado no professor.

\footnotetext{
11 Em dissertação de mestrado, Rocha (1996), conclui que "foi da França que "se" transplantou" o ideal de educação, o modelo de organização escolar, a forma,bem como os conteúdos, adotados pelas disciplinas".A Geografia ensinada nas escolas brasileiras reproduziu quase que integralmente o currículo das escolas francesas. Até mesmo os manuais didáticos (compêndios) eram franceses.
} 
A herança deste ensino descritivo sobre os lugares feitos por recortes conforme aponta vários estudos e dissertações de mestrado e doutorado é de origem francesa dos estudos regionais cujo seu principal pensador é Vidal de La Blache. Para este Geógrafo, estudar Geografia é fazer a região e o método da análise regional consistia resumidamente em: "observação de campo, introdução a partir da paisagem, particularização da área enfocada (traços históricos e naturais), comparação entre as áreas estudas, do material levantado e classificação das áreas e dos gêneros de vida, em séries de tipos genéricos, devendo chegar, no final, a uma tipologia" (Pontuschka, 2001: 116 - 117). Essa geografia regional é hegemônica desde a institucionalização da Geografia no Brasil, nos anos de 1930, até os nos 1970 e que de certa maneira existe até hoje, nas escolas, nos currículos e livros didáticos. Outra marca importante deste momento é a explicação objetiva e quantitativa da realidade e o argumento da neutralidade científica em buscar estudar as relações homem-natureza. Várias obras didáticas, programas e currículos escolares utilizam o recorte regional como ponto de partida para ensinar Geografia e muitos professores ainda trabalham na perspectiva regional.

Nessa perspectiva podemos citar, como exemplo, o documento de reorientação curricular da SEE-RJ $(2005,2006)$ que ainda adota esta metodologia regional na qual todo programa para o ensino fundamental ainda está estruturado no conceito de regiãocontinente ( $6^{\mathrm{a}}$ série: $\mathrm{O}$ Espaço Brasileiro, $7^{\mathrm{a}} \mathrm{O}$ continente Americano, Oceania e Antártica, $8^{\text {a }}$ Organização do Espaço Mundial).

Silva (1996) afirma que durante o período de 1930 a 1970 consagrou-se um ensino de Geografia compartimentalizado na estrutura Natureza-Homem-Economia que exaltava o Estado e que esta estrutura foi muito difundida no ensino escolar pelas obras de Aroldo Azevedo que no período de 1934 a 1974 vendeu mais de 11 milhões e 200 mil exemplares, cifra bastante expressiva para o período e até para os dias atuais. Afirma ainda, que não se tem notícia de em outra área de ensino de tamanha hegemonia. Aponta que a disseminação do livro didático da maneira como ocorreu caracterizou a difusão de forma e conteúdo arraigado de uma concepção de mundo, consolidando na sociedade brasileira uma forma exclusiva de ler geograficamente o Brasil e/ou outros fenômenos.

Aroldo Azevedo elaborou uma leitura regional Geográfica que se baseia nos delineamentos do positivismo funcionalista. Estes se caracterizavam 
em termos operacionais nos compêndios didáticos, através da visão fragmentada de mundo, pautando as investigações geográficas a partir da elucidação e junção das partes constitutivas do fenômeno. Em outras palavras, o estudo primeiro dos aspectos físicos, depois os humanos e concluindo os aspectos econômicos, para depois fazer interligações possíveis.

É importante sinalizar que esse tipo de fundamentação teóricometodológica criou marcas indeléveis dentro da seara geográfica, pois grande parte da profícua produção do autor no período que vai do final da década de 40 até a sua última publicação apoiou-se nesse tipo de problematização. As várias reedições dos seus textos no período em foco ao tratarem do tema apresentavam frontispício (e ao longo da obra) a estruturação da lógica de ordenação dos temas e análise na clássica divisão, que estamos salientando: A Terra - o Homem - a Economia. (Silva, 1996: 118).

Silva ainda citando Aroldo de Azevedo procura identificar e evidenciar as fundamentações teórico-metodológicas do referido autor cujo único objetivo era de traçar as linhas mais marcantes do período. Ressalta que por toda obra de Azevedo a utilização de conceitos básicos da Geografia Lablachiana ocorreu de forma intensa, como o conceito de região e de gênero de vida. Pondera ainda que a Geografia de deste autor se aproxima de uma postura antiga que acompanhou boa parte de intelectuais brasileiros na consolidação do conhecimento cientifico no Brasil, - o ecletismo ${ }^{12}$.

Na Escola, o ensino de Geografia, baseado no padrão N-H-E reificou um modelo de explicação do mundo baseado na descrição das características das regiões. Neste sentido o objeto de estudo da Geografia é o de explicar a região. Com isto desenvolveuse uma abordagem fragmentada moldada pelas "especialidades da Geografia" - o estudo do relevo, dos diversos climas, das formas vegetais, da distribuição da população, das redes de cidades, da localização das principais atividades econômicas. Por outro lado, a fragmentação da abordagem - principalmente a cisão entre as chamadas Geografia Física e Geografia Humana - consolidou o caráter descritivo da Geografia Tradicional. A Geografia Física tornou-se o terreno da classificação de tipos (de unidades de relevo, climas, hidrografia, vegetação) e de sua delimitação territorial.

\footnotetext{
12 Silva (1996) afirma que a significação da palavra ecletismo implica admitir um sistema de doutrinas articulado em cima da infiltração de idéias de outros sistemas, caracterizando-se pela falta de originalidade e principalmente pela falta de coesão. Para este autor a maneira de conceber o processo reforça o não treinamento acurado do cientista para a compreensão e significâncias das diversas correntes teórica-metodológicas diferenciadas que compunham o pensamento cientifico do período.
} 
O ensino de Geografia do Brasil na escola básica, ainda é marcado por esta lógica fragmentada. Lógica que herdamos dos estudos da geografia francesa ${ }^{13}$ que, no Brasil foi muito bem sedimentada por geógrafos franceses ${ }^{14}$ que vieram contribuir com a criação dos cursos de Geografia da Universidade de São Paulo e da Universidade do Distrito Federal na cidade do Rio de Janeiro.

A partir dos anos 1970 há uma revisão das bases teóricas e metodológicas da ciência geográfica, com repercussão no ensino. Vários estudos denunciaram as fragilidades de um ensino com base na Geografia Tradicional e propuseram um ensino de uma Geografia Nova, com base em fundamentos críticos.

Silva (2006) afirma que na década de 1980 constata-se um expressivo aumento da discussão dos fundamentos da Geografia e seu papel na sociedade, no ensino ou em outras instituições sociais. Essas discussões giravam em torno das condições do ensino, das críticas em relação aos conteúdos e aos fundamentos da ciência geográfica. Afirma que neste período, professores ligados a AGB sinalizaram a necessidade da inovação dos temas tratados pelo ensino de Geografia e que novos temas fossem inseridos no ensino desta ciência. Entretanto, o autor afirma que a discussão pedagógica ficou limitada no plano dos conteúdos.

\begin{abstract}
A introdução de novos temas mais ligados à vida trouxeram a efervescência necessária para o delineamento de uma "Geografia Crítica". Tais temas alguns fortemente marcados pela economia política, surgiram através da análise do papel do Estado, das multinacionais, dos blocos econômicos, da burguesia, da imprensa, das relações internacionais, da Guerra fria, da luta de classe, do desarmamento, das minorias, enfim, praticamente tudo ficou cabendo nas aulas de Geografia. (Silva, 2006: 316)
\end{abstract}

Ainda segundo Silva sem uma preocupação pedagógica e metodológica a Geografia amplia os temas a serem abordados nas salas de aula, e isto, provoca de

\footnotetext{
${ }^{13}$ A forte perspectiva regional criada por Vidal de La Blache afirmou a visão funcionalista dentro da Geografia. Esse desdobramento deu margem às interpretações que assinalam existir uma escola francesa de Geografia, tanto na esfera teórica quanto na esfera operacional (Silva, 1996).

Segundo Isabelle Lefort (2004) de 1902 até 1977 o ensino Geografia na França submete-se a proeminência do paradigma vidalino. Neste período o ensino de Geografia francês incorpora os avanços científicos da escola vidalina. A Geografia ensinada dá lugar aos princípios de Geografia geral e Geografia regional a ciência Geográfica é vista como disciplina de síntese, apoiando-se sobre o trinômio descrição-comparação-explicação das paisagens e os gêneros de vida da superfície da terra.

${ }^{14}$ Conforme aponta Vlach (2007) e Rocha (1996), Pierre Deffontaines (1934-1935) e Pierre Monbeig (1935-1946), esses dois geógrafos foram fiéis discípulos da escola francesa de Geografia e foram os primeiros professores de Geografia do curso de Geografia e História da Universidade de São Paulo e François Ruellan, na Faculdade Nacional do Rio de Janeiro.
} 
alguma maneira, uma crise de identidade nas aulas desta disciplina, pois, "como cabe tudo no ensino de Geografia, perdemos nossa identidade, ora falamos de temas com a cara da história, ora, com a cara da economia" (Silva, 316). Isso, sem contar, que passamos a negligenciar a cartografia, pois na negação daquilo que chamamos de geografia tradicional, mnemônica e descritiva, a cartografia acaba por entrar rol de conteúdos a ser negado, pois, nas aulas desta disciplina o seu perfil é o da descrição do mapa.

Vesentini (1992) também propõe novos conteúdos para o ensino de Geografia e aponta para a necessidade de abandonar ou de repensar os temas tratados pela geografia tradicional.

Um ensino de Geografia voltado para criticidade do aluno, para formação de cidadãos plenos, não consiste pura e simplesmente em renovar os mesmos temas da geografia tradicional mas, principalmente, em repropor tudo: excluir certos assuntos (tais como princípios da geografia, geografia astronômica ou evolução da Geografia, para citar apenas três exemplos), desenvolver itens novos como degradação ambiental, a situação da mulher na sociedade moderna, a questão da burocracia e da democracia, etc.) e retrabalhar os restantes. Retrabalhar, por exemplo, agricultura: ela nunca deve ser vista antes de indústria, como fazia o ensino tradicional, mas depois desta, como subordinada aos interesses urbanos industriais. Retrabalhar, igualmente a regionalização do espaço mundial: não se deve partir dos continentes (América, Ásia, áfrica, etc.), mas sim de uma discussão dessa mesma problemática para se chegar a uma regionalização com base no social (divisão internacional do trabalho, o capitalismo mundial - seu centro e periferia(s) -, o "socialismo real", etc.) E, sobretudo, repensar o ponto de partida para estudar alguma realidade nacional: A Geografia tradicional possui um esquema pré-definido (a localização, as coordenadas geográficas, o meio físico, etc.) que é necessário abandonar.(Vesentini, 1992: 65)

Esse tipo de perspectiva para o ensino de Geografia marcou profundamente os documentos de orientações curriculares, no período dos anos 1980, e toda uma geração de professores e novos autores de livros didáticos. Passou a ocorrer uma inovação na apresentação de temas nada tradicionais no ensino de Geografia. A Geografia crítica passa a utilizar novos referencias para a construção dos conteúdos escolares onde a marca que predomina é a recusa de desenvolver um saber politicamente comprometido com o Estado e com o grande capital. 
Outro aspecto de grande importância neste momento de renovação é que a Geografia Crítica, a princípio, minimizou a reflexão sobre novos procedimentos de ensino-aprendizagem fazendo prevalecer à lógica conteudística que predominava no período anterior. Os novos currículos e programas priorizaram o acúmulo de informações em detrimento da ênfase no desenvolvimento de novas formas de linguagem. Porém, isto não significa que alguns autores não tenham buscado outros caminhos. Talvez, a explicação pela permanência da lógica conteudística explica-se pela revalorização dos conteúdos como instrumentos de transformação social.

\subsubsection{As transformações nos currículos de Geografia e os novos conteúdos}

No final dos anos 1980 e ao longo dos anos de 1990, passa a ocorrer um incremento na inovação da discussão sobre o papel da Geografia na escola, vários autores e propostas curriculares, procuraram trazer para dentro da discussão da Geografia escolar o papel dos conteúdos desta ciência no processo de ensinoaprendizagem. As novas propostas curriculares do período mudam o foco do debate e levam as questões relativas aos conteúdos para dentro da discussão pedagógica.

Essas posturas, relacionadas a mediação da discussão conteudística pela pedagógica buscam no seu âmago construir uma alfabetização em Geografia. Isto é, participar do processo de letramento do educando, oportunizando desenvolver sem atropelos pelos conteúdos significativos, das aulas de Geografia, uma série de habilidades como observar, descrever, relacionar, interpretar, analisar e criticar. Ao mesmo tempo em que a construção dos conceitos geográficos vai se desenrolando, criando condições para o esclarecimento do significado, utilidade e dinâmica que os diferentes lugares e paisagens têm entre si e com nossas vidas. (Silva, 2006: 319)

Neste momento os conteúdos tornam-se meios para atingir determinados objetivos e não o fim em si mesmo. Os conteúdos são instrumentos para formar conceitos geográficos e esses conceitos servem para formar um raciocínio espacial ${ }^{15}$. A preocupação agora é de construir um método que leve o aluno a pensar e ler o espaço geográfico. Nas novas propostas curriculares para o ensino de Geografia o professor é

\footnotetext{
${ }^{15}$ Cavalcanti, 2002
} 
visto como mediador ${ }^{16}$ do processo de alfabetização do espaço geográfico, ensinar Geografia e aprender a ler o mundo através de através de uma rede ou um sistema conceitual próprio desta ciência (Espaço, Território, Lugar, Paisagem, Região, Natureza, Sociedade, etc.).

Cavalcanti (2002) faz um balaço provisório das reformas curriculares neste período, afirma que as propostas de reorganização curricular por parte dos órgãos públicos e a criação dos Parâmetros Curriculares Nacionais pelo Ministério da Educação na década de 1990 e as orientações curriculares para o ensino médio (2002, 2004 e 2006) reacenderam o debate entre pesquisadores e professores no que envolve o ensino de Geografia e os currículos escolares desta disciplina. Para a autora o conteúdo do debate pode ser definido em duas posições: a primeira que consolida um projeto oficial para o ensino de forma mais ampla e o ensino de Geografia na forma mais específica; a segunda, posiciona-se contra a este projeto defendendo mais autonomia do ensino desta ciência em relação as proposições oficiais.

Entretanto nas reformas curriculares deste período Cavalcanti percebe convergências de caráter teórico-metodológico ou "idéias motrizes" entre os diversos grupos que pensam de forma diferente sobre o caráter de uma proposta oficial de ensino para Geografia. Afirma que tais convergências são positivas na consolidação e no avanço desta disciplina na escola. Para a autora as a "idéias motrizes" e as características teórico-metodológicas através das quais se desenvolvem as novas propostas curriculares para o ensino de Geografia são:

- O Construtivismo como atitude básica do trabalho com a Geografia escolar;

- A "Geografia do aluno" como referência do conhecimento geográfico construído em sala de aula;

- A seleção de conceitos geográficos básicos para estruturar os conteúdos de ensino;

- A definição de conteúdos procedimentais e valorativos para a orientação das ações, atitudes e comportamentos sócio-espaciais. (Cavalcanti, 2002: 30)

\footnotetext{
${ }^{16}$ Nesta concepção o professor não é mais aquele agente único do processo de ensino, como o único detentor do conhecimento que "transmite" o conteúdo para o aluno, que por sua vez assimila sem maiores questionamentos. Para Cavalcanti (2002) o processo deformação de professores numa perspectiva mediadora requer o desenvolvimento de uma competência crítico-reflexiva, que lhes forneça meios de pensamento autônomo, que facilite dinâmicas de autoformação, que permita a articulação teoria e prática do ensino.
} 
De certa forma todos os itens apresentados pela professora Lana Cavalcanti aparecem nas propostas curriculares que veiculam no Brasil, nas últimas duas décadas, com destaque para os PCNs para o ensino fundamental, PCNEM e Orientações Curriculares de Geografia para o ensino médio. Esses itens também aparecem em vários livros didáticos e manuais dos professores como opções metodológicas para um melhor desenvolvimento do ensino desta ciência.

Entendemos também que efetivamente muitos professores ainda desconhecem essas novas propostas metodológicas e que em várias escolas e redes de ensino espalhadas pelo país ainda adotam um ensino tradicional desta ciência. Já no documento de Reorientação Curricular para o ensino de Geografia do estado do Rio de Janeiro percebemos algumas proposições no sentido de adotar essas novas formulações mais uma análise mais detalhada sobre o tema, buscando compreender se essas proposições aparecem de fato, faremos no capítulo III desta pesquisa.

No entanto, de todos os itens apresentados anteriormente nas novas propostas curriculares, três aparecem recentemente de forma mais marcante: 1) A seleção dos conceitos básicos para estruturar os conteúdos de ensino, 2) Os conteúdos procedimentais e valorativos para a orientação das ações, atitudes e comportamentos sócio-espaciais e 3) o construtivismo. Já a "Geografia do aluno" como referência do conhecimento geográfico, ou o espaço real e "vivido" encontramos citados em trabalhos dos anos de 1980 como Resende, Paganelli, Vesentini, dentre outros conforme comprova o professor William Vesentini no início dos anos 90.

Outro elemento importantíssimo é a realidade social do aluno, os seus interesses existenciais. Por exemplo, não deixamos de enfocar a questão agrária quando estamos acampando para filhos de assentados ou de "bóias frias". E não podemos deixar de trabalhar a questão da violência policial para alunos da Periferia dos grandes centros urbanos. Da mesma forma, é extremamente motivador (e motivação é algo basilar para o ensino) abordar a questão da mulher e do feminismo em turmas de secretariado. E assim por diante. Ou seja: não se trata nem de partir do nada, nem de simplesmente aplicar o saber científico; deve haver uma relação dialética entre esse saber e a realidade do aluno - daí o professor não ser um mero reprodutor, mas um criador. (Vesentini, 1992: 58)

Parece claro que a Geografia crítica busca trazer para dentro de si e do ensino uma aproximação, cada vez maior da ciência com a realidade dos educandos. Contudo a tradição conteudística leva em primeiro lugar as transformações dos conteúdos, mas o 
como ensinar esses novos conteúdos é uma questão a ser construída e desenvolvida. Vejamos o que diz Resende em 1986.

Acredito que tal integração do "espaço real" do aluno com o espaço geográfico que queremos ensinar-lhe (integração dialética, isto é, pela passagem do particular ao geral) é não somente desejável, mas de fato possível no dia-a-dia da escola formal, e trará com certeza benefício a nossa prática de ensino de Geografia, motivando o aluno a aprender e levando-o à descoberta progressiva do seu espaço na escola - o de sujeito no processo de conhecimento.

Não tenho, porém, receitas mágicas para fazê-la. Seria desonestidade e/ou imperdoável soberba negar a complexidade de semelhante tarefa. Elaborar currículos, programas, estratégia e instrumentos didáticos para uma Geografia e um aluno que nega tanto os dogmas de nossa formação universitária quanto aqueles de nossa rotina profissional exigirá sem dúvida de empenho coletivo e constante experimentação dos professores da área. (Resende, 1986: 164).

Empenho coletivo e constante experimentação dos professores da área. É isto que parte dos professores de Geografia buscaram construir ao longo dos últimos vinte anos, uma nova forma de abordar os temas tratados pela Geografia. A cidade/campo, a indústria, o relevo, o clima e a vegetação e tantos outros temas precisavam não somente ser reelaborados, mas repensados dentro de novas práticas pedagógicas.

A pesquisa sobre o ensino de Geografia ampliou-se. Os encontros, congressos e seminários sobre ensino de Geografia, práticas de ensino em Geografia e pesquisas de ensino de Geografia multiplicaram-se. As publicações sobre ensino desta disciplina cresceram exponencialmente e novas obras didáticas, para os professores e alunos, surgiram com novas abordagens onde sua principal marca é, sem dúvida, uma aproximação maior com a pedagogia.

Fica claro que ao longo dos anos de 1990 o ensino de Geografia na escola, procurou buscar mecanismos e novas metodologias para que a compreensão do espaço geográfico e/ou espaço "vivido" ocorresse de forma sistematizada, bem menos "conteudística". Daí compreender o que foi exposto, anteriormente, pela professora Lana Cavalcanti não de forma estanque, separada, porém, coesa. Compreender o "espaço vivido" requer um jogo conceitual e como proceder com este jogo conceitual para alcançar tais objetivos (como ler o mundo e suas contradições). É nesse sentido, que vários pesquisadores no campo do ensino da Geografia escolar passaram a buscar 
elementos para a construção de novos currículos e programas em outros campos do conhecimento com ênfase na pedagogia e na psicologia da aprendizagem.

\subsubsection{Construtivismo, cartografia e o currículo de Geografia}

Elaborar uma proposta curricular numa perspectiva construtivista ${ }^{17}$ aparece como referência importante e um novo elemento de destaque nas novas formulações curriculares como, por exemplo, a construção da noção de espaço na cartografia. Isso significa que o aluno terá que desenvolver as noções espaciais topológicas, projetivas e euclidianas ou relativas as noções de área, ponto de referência, tamanho para que possamos trabalhar os conceitos de escala, localização e pontos cardeais.

As propostas pedagógicas de cunho construtivista consideram o ensino como um processo de construção de conhecimentos e o aluno como sujeito ativo nesse processo. Nessa ótica, o ensino de Geografia deve considerar o aluno como sujeito que tem um universo de saberes já elaborados por ele em sua vida cotidiana, pois quando ele observa a realidade estabelece conexões com os conteúdos que estão sendo trabalhados.

Ao se estruturar uma proposta curricular, como os PCNs, que tem uma base teórica construtivista, na medida em que se propõem procedimentos que o aluno tenha que desenvolver habilidades, como observar classificar e comparar. No ensino da Geografia essas concepções aparecem com destaque no processo de alfabetização cartográfica, porque é a mesma lógica da alfabetização da língua portuguesa. Parece que, sem sombras de dúvidas, a maior influência do construtivismo no ensino de Geografia encontra-se na cartografia.

Isso ocorre porque a teoria piagetiana contribui para que o professor reconheça como os alunos, em diferentes faixas etárias constroem as noções básicas de espaço. Do ponto de vista do construtivismo, a construção da noção de espaço requer longa preparação e está associada à liberação progressiva e gradual do egocentrismo que a criança exerce nos primeiros anos de vida. A construção das relações espaciais requer a interação do sujeito com meio em que vive e realiza-se através da liberação progressiva

\footnotetext{
${ }^{17}$ Segundo Castellar (2005) no Construtivismo, "O conhecimento é visto não como mera cópia do mundo exterior, mas como um processo de compreensão da realidade, a partir das representações que as pessoas têm dos objetos e fenômenos (significados), em consonância com seus próprios conhecimentos e experiências (ações). Portanto, a aprendizagem nessa perspectiva, consiste em conjugar, confrontar ou negociar o conhecimento entre o que vem do exterior e o que há no interior delas".
} 
e gradual do egocentrismo primitivo. Há três tipos de relações espaciais. As relações espaciais topológicas, projetivas e euclidianas.

As relações espaciais topológicas são limitadas às prioridades inerentes a um objeto particular, sem que intervenha a necessidade de situar este objeto em relação a um outro, são as noções espaciais mais elementares que envolvem vizinhança, separação, ordem ou sucessão, envolvimento ou fechamento, continuidade. As relações projetivas permitem a coordenação dos objetos entre si num sistema de referência móvel, dado pelo ponto de vista do observador. Inicialmente o ponto de referência está centrado na própria criança, aos poucos é transferido para outras referências, ou seja, ocorre a descentração. As noções fundamentais que envolvem as relações projetivas são as noções de direita e esquerda, frente e atrás, em cima e em baixo e ao lado de. Por último, as relações euclidianas são representadas pelas relações que têm como base a noção de distância e permitem situar os objetos uns em relação aos outros, considerando um sistema fixo de referência.

A evolução da forma de apreensão do espaço pela criança segue três etapas essenciais: O espaço vivido que é o espaço físico construído pelos deslocamentos de engatinhar e andar e pelos sentidos; o espaço percebido que ocorre quando a criança começa a analisar o espaço através da observação; e o espaço concebido que é o espaço mais abstrato, construído pela reflexão (Almeida \& Passini, 2006). Nesse sentido, quando o professor se apropria dessas noções, consegue planejar e desenvolver atividades que permitam as crianças alfabetizar-se na linguagem cartográfica.

$\mathrm{Na}$ Educação Geográfica Castellar (2005) argumenta que a teoria piagetiana contribui na perspectiva do desenvolvimento da linguagem cartográfica como primeiro passo para compreender conceitos geográficos. Afirma, "para tanto a relação simbólica, as relações espaciais, a reversibilidade fazem parte do processo de letramento cartográfico, ou seja, na cartografia escolar, na medida em que a criança lê e elabora mapas mentais necessita compreender o significado dos símbolos e signos”. E segue afirmando:

Desse modo, a Geografia escolar, ao utilizar a linguagem cartográfica como metodologia para construção do conhecimento geográfico, lança mão desses fundamentos - como dominar as noções de conservação de quantidade, volume e peso, superar o realismo nominal e compreender as relações espaciais topológicas, projetivas e euclidianas - para estruturar um esquema de ação, na medida em que ajudará a criança na construção progressiva das relações espaciais tanto no plano perceptivo quanto no 
plano representativo; neste a criança já adquiriu a linguagem e a representação figurada, isto é, segundo Piaget, a função simbólica em geral. Assim, contribuirá para que ela leia e elabore mapas cognitivos e qualquer outro tipo de mapas. (Castellar; 2005: 45).

A cartografia neste momento volta a ser extremamente valorizada e passa a ganhar maior destaque nos guias curriculares, programas e livros didáticos. Passa a ocorrer um "resgate da cartografia", não mais como um simples conteúdo a ser ensinado em um capítulo a parte, mais como uma ferramenta importante na compreensão do espaço geográfico, na leitura do mundo.

A cartografia, então, é considerada uma linguagem, um sistema de código de comunicação imprescindível em todas as esferas de aprendizagem, articulando fatos, conceitos e sistemas conceituais que permitem ler e escrever as características do território. Neste contexto a cartografia escolar é uma opção metodológica, o que implica utilizá-la em todos os conteúdos da Geografia, quando identifica e reconhece não apenas a localização dos países, mas entende as relações entre os países, os conflitos e a ocupação do espaço, a partir da interpretação e leitura de códigos específicos da cartografia. (Castellar, 2005: 45).

Podemos considerar que os PCNs também contribuem incisivamente na revalorização da cartografia quando enquadram-na como competências e habilidades imprescindível no ensino da Geografia escolar. Para os PCNs do ensino médio ler, analisar e interpretar códigos específicos da Geografia (mapas, gráficos, tabelas etc.) são competências que permitem reconhecer e aplicar o uso das escalas cartográficas e geográfica, como formas de organizar e reconhecer a localização, distribuição e freqüência dos fenômenos naturais e humanos (Brasil, 2002).

\subsubsection{Repensando os conteúdos nos currículos de geografia.}

Outro referencial importante na construção dos currículos vigentes é a idéia de conteúdo que para a maioria dos professores significa informação de fatos e acontecimentos. Essa tendência predominante sobre o entendimento dos conteúdos na educação escolar retificou uma prática pedagógica pautada pelo binômio transmissãoincorporação, considerando a incorporação de conteúdos pelo aluno como a finalidade essencial do ensino. 
Os Parâmetros Curriculares Nacionais propõem uma mudança de enfoque em relação aos conteúdos curriculares, pois estes sempre estiveram associados aos conhecimentos de tipo conceitual (fatos, noções, conceitos e princípios), diferenciados das capacidades, habilidades e atitudes. Ao invés de um ensino em que o conteúdo seja visto como fim em si mesmo, os PCNs propõe um ensino em que o conteúdo seja visto como meio para que os alunos desenvolvam as capacidades que lhes permitam produzir e usufruir dos bens culturais, sociais e econômicos. Sendo assim, a noção de conteúdo escolar se amplia para além de fatos e conceitos, passando a incluir procedimentos, valores, normas e atitudes.

Nesta perspectiva os conteúdos são abordados em três grandes categorias: conteúdos conceituais, que envolvem fatos e princípios; conteúdos procedimentais e conteúdos atitudinais, que envolvem a abordagem de valores, normas e atitudes (Coll; 1996).

Os conteúdos conceituais referem-se à construção ativa das capacidades intelectuais para operar com símbolos, idéias, imagens e representações que permitem organizar a realidade. Já os conteúdos procedimentais expressam um saber fazer, que envolve tomar decisões e realizar uma série de ações, de forma ordenada e não aleatória, para atingir uma meta. E por último os conteúdos atitudinais que permeiam todo o conhecimento escolar, esses conteúdos referem-se à formação de valores, atitudes e convicções. A escola é um contexto socializador, gerador de atitudes relativas ao conhecimento, ao professor, aos colegas, às disciplinas, às tarefas e à sociedade.

Cavalcanti (2002) aborda a idéia dos conteúdos procedimentais e atitudinais dentro do ensino de Geografia. Para esta autora, os professores desta disciplina devem em suas aulas, ir além do estudo dos fatos, das definições e da valorização exclusiva dos aspectos cognitivos de ensino.

O ensino é um processo que compõe a formação humana em sentido amplo, apanhando todas as dimensões humanas da educação: intelectual, afetiva, social, moral, estética e física. Para isso, necessita não só para construção de conceitos, mas também para o desenvolvimento de capacidades e habilidades para se operarem esses conhecimentos e para formação de atitudes, valores e convicções ante os saberes presentes no espaço escolar. (Cavalcanti, 2002: 37).

E aponta o que seriam os conteúdos procedimentais e os conteúdos atitudinais no ensino de Geografia. 
Os conteúdos procedimentais, em Geografia, dizem respeito àqueles temas trabalhados nas aulas com o intuito de desenvolver habilidades e capacidades para se operar o espaço geográfico. É a capacidade de observação de paisagens, de descriminação de elementos da natureza, de usos de dados estatísticos, cartográficos.

Os conteúdos atitudinais e valorativos referem-se à formação de valores, atitudes e convicções, que perpassam os conteúdos referentes a conceitos, fatos, e informações. Trata-se daqueles conteúdos que auxiliam o aluno a agir no espaço, a influir na sua produção de acordo com determinados valores convicções, como por exemplo, a atitude de participação ativa na construção e produção da moradia, coresponsabilidade com a gestão dos territórios, valorização da vida no espaço, respeito ao direito das pessoas pelo deslocamento no espaço. (Cavalcanti, 2002: 38-40).

Para o geógrafo William Vesentini que também segue na mesma perspectiva de que uma educação crítica e um ensino de Geografia crítico não se deve trabalhar, apenas conteúdos conceituais, mas também atitudes e procedimentos para desenvolver habilidades.

Portanto, um ensino da Geografia crítica não se limita a uma renovação do conteúdo - com a incorporação de novos temas/problemas, normalmente ligados às lutas sociais: relações de gêneros, ênfase na participação do cidadão morador/trabalhador e não ao planejamento, compreensão das desigualdades e exclusões, dos direitos sociais (inclusive os do consumidor), da questão ambiental e das lutas ecológicas etc. Ela também implica valorizar determinadas atitudes combate aos preconceitos; ênfase na ética, no respeito aos direitos alheios e às diferenças; sociabilidade e inteligência emocional - e habilidades (raciocínio, aplicação/elaboração de conceitos, capacidade de elaboração e de crítica etc.). E para isso é necessária uma adoção de novos procedimentos didáticos: não mais apenas ou principalmente a aula expositiva, mas sim, estudos do meio (isto é trabalhos fora de sala de aula), dinâmicas de grupo e trabalhos dirigidos, debates, uso de computadores (e suas redes) e outros recursos tecnológicos, preocupações com atividades interdisciplinares e com temas transversais etc.(Vesentini, 2004: 228)

Portanto, que mais vale para o ensino moderno, e o ensino de Geografia no período vigente, são as atitudes cognitivas (raciocínio lógico, criticidade, etc.), e não o conhecimento em si que na realidade é, sobretudo um instrumento para desenvolver certas potencialidades do educando. 


\subsubsection{Os conceitos que estruturam os novos currículos de Geografia.}

Por último, os atuais currículos de Geografia trazem uma nova seleção de conceitos geográficos básicos para estruturar os conteúdos de ensino. Cacete, Paganelli, Pontuschka (2007) afirmam que durante muito tempo os conceitos que alicerçaram o conhecimento geográfico foram o de região, paisagem e o de gênero de vida. Esses conceitos foram essenciais para análise dos espaços, assim como, atualmente, são valorizados os conceitos de espaço, território região e lugar. Afirmam que outros conceitos também foram estruturantes no ensino de geografia: o conceito de sítio (o lugar e suas características físico-naturais, humanas econômicas, políticas) e o de situação (relação do lugar e de sua região nas escalas regional, nacional e internacional), nos anos de 1960. Já “os conceitos de região homogênea, região polarizada, hierarquia urbana e área metropolitana entraram, posteriormente, no vocabulário geográfico escolar, facultando as estruturas básicas do espaço geográfico mediante a classificação por homogeneidade e a relação dos lugares por polarização (Cacete, Paganelli, Pontuschka, 2007: 121)".

Atualmente o ensino de geografia sofre diferentes posições teóricometodológicas de vários autores, contudo, muitos, compartilham de um mesmo posicionamento, a preocupação de ampliar o ensino de Geografia para além dos conteúdos.

Como exposto anteriormente, a Geografia como disciplina escolar sempre foi arraigada por conteúdos mnemônicos e factuais suas aulas sempre foram marcadas pela memorização de fatos e acontecimentos. O movimento de renovação da Geografia no Brasil buscou construir novos currículos que não tivessem este caráter, buscou integrar as "gavetas", o padrão N-H-E, construiu novos conteúdos que dessem conta de explicar o espaço geográfico, esse que é produzido socialmente, resultante das contradições da sociedade capitalista, fruto das relações de trabalho que transforma a primeira natureza em uma segunda natureza. O clima, o relevo, o solo, o curso de um rio, as formas vegetais, a distribuição das indústrias passaram a ser ensinadas, nas aulas desta disciplina, de forma articulada, visto como um movimento da totalidade.

Entretanto, esses novos conteúdos e, ou, conteúdos transformados por uma nova concepção teórico-metodológica continuaram a ter um fim em si mesmo, ou seja, os conteúdos continuaram sendo objetivos. Por exemplo, o objetivo de ensinar sobre o processo de urbanização é o de compreender o processo de urbanização, ou ainda, 
ensinar as regiões brasileiras é entender que no Brasil há cinco ou três regiões dependendo do tipo de regionalização.

Por exemplo, ao se definir que o objetivo do estudo do conteúdo "indústria brasileira" é fazer com que o aluno saiba o que é a "indústria brasileira". E aí sem saber, o professor começou a adotar a lógica do cachorro que corre atrás de seu próprio rabo e consegue apenas ficar cansado. (Pereira, 1995: 62).

Além de concordarmos com Pereira que o estudo do conteúdo acaba criando uma lógica própria que tem um fim em si mesmo apontamos também para uma outra proposição. O tema indústria brasileira é um fenômeno que pode ser tratado por economistas, engenheiros, sociólogos, historiadores e outros campos do conhecimento. Portanto, o simples fato de falarmos sobre a indústria brasileira não diz que nossas aulas são de Geografia. É preciso que toda a nossa reflexão tenha como referência um conjunto de categorias e conceitos que sejam próprios da ciência geográfica. Daí a necessidade de ensinar geografia mediante a construção de conceitos que são próprios desta ciência: espaço lugar, território, paisagem, região (conceitos que fazem referência a localização) e outros próximos da ciência geográfica como sociedade e natureza. Entende-se que são esses conceitos que vão fomentar capacidades para que os alunos formem raciocínios espaciais.

Em síntese, a Geografia escolar busca construir uma fundamentação teóricometodológica para atribuir significado ao que se ensina. Entendemos, que novas propostas teórico-metodológicas possui bases não só na Geografia acadêmica, mas em outros campos do conhecimento como a psicologia, a didática e a pedagogia. Desde a década de 1980 a Geografia amplia seus referenciais interpretativos da realidade e neste movimento surgem novos e diversos caminhos da investigação geográfica que se cristalizam na ampliação das pesquisas sobre o ensino de geografia comentar as pesquisas. As pesquisas sobre este campo ampliam-se por vários caminhos e disseminam-se novas formas de ensinar esta ciência.

Entretanto, ao final, ficam algumas indagações. Já que a disciplina escolar geografia, na atualidade, é fruto do movimento da ciência geográfica articulado com as transformações que ocorrem no ambiente escolar e que atende por concepções hegemônicas, de determinados grupos com interesses diversos, em períodos específicos. Qual momento ou quais os momentos, dos três períodos mencionados no texto, 
consolidarão de forma mais expressiva nos currículos desta disciplina escolar? No caso de nossa pesquisa, o documento de Reorientação Curricular incorpora, de forma efetiva, qual momento?

Entendemos que partindo da nossa "tradição geográfica" os três momentos aparecem no documento de Reorientação Curricular, porém compreendemos que o mesmo não apresenta os três de forma homogênea. E isso se deve porque o currículo nunca é uma seleção neutra. Selecionar os conteúdos é uma tarefa política que demonstra relações de poder, assim como construir guias curriculares.

As próximas páginas deste trabalho são dedicadas a contextualizar o documento de Reorientação Curricular dentro do cenário de transformações em que o Mundo produtivo passa nos dias atuais. Um currículo é sempre um ato político que visa construir um modelo de educação que sintetiza um modelo de sociedade. 


\section{Contextualizando a Reorientação Curricular por dentro das reformas neoliberais.}

A proposta de Reorientação Curricular do governo de Estado do Rio de Janeiro, para as escolas públicas, não ocorre no vazio e não se faz somente no terreno das idéias. Ao contrário, elas se desenvolvem no terreno concreto da história. Uma proposta de reforma não se faz sem objetivos claros e definidos. Toda proposta de reforma educacional se faz com objetivo de mudar a escola e a escola não está desconectada das mudanças que do mundo sofre.

É nessa direção, de que existe uma simbiose nas transformações que ocorre na escola com as mudanças que ocorrem no mundo, que nos leva a concordar com PortoGonçalves quando afirma que:

Toda proposta de reforma da educação visa construir um determinado mundo; é, assim, uma visão de mundo está sendo proposta. Sendo assim, toda proposta de reforma da educação aparece como crítica à educação que se tem, condição essa que visa credenciar a proposta que se faz (Porto-Gonçalves, 1999: 71).

Portanto, a escola que se tem hoje, para determinados segmentos da sociedade, perdeu o sentido do tempo e está defasada em relação às transformações que o mundo vem sofrendo. É nesse sentido, que a questão fundamental nessa parte de nossa pesquisa, passa "ser a de identificar que concepção de mundo está subjacente às propostas de reforma no mundo da educação que vem nos sendo (im)postas nos dias que correm e mais do que isso, em que terrenos elas emergem para que tentemos identificar os sujeitos que através delas vêm tentando (im)por o seu mundo"(Gonçalves, 1999: 72).

As transformações no mundo do trabalho e no mundo da educação, não são desconectadas das transformações que o capitalismo, em sua totalidade, sofre desde os anos de 1970 até os dias atuais. Transformações essas de caráter neoliberal que são pautados numa nova forma dos Estados intervirem nos processos políticos e econômicos.

As políticas educacionais no Brasil e em vários países emergentes, estão associados a acordos internacionais com instituições e organismos multilaterais. Essas políticas transparecem nas propostas curriculares atuais e são freqüentemente associadas 
à crescente subordinação dos Estados nacionais às exigências desses organismos, como a Unesco, o Banco Mundial (Bird) e o Banco Interamericano de Desenvolvimento (BID) (Lopes, 2008).

A partir da década de 1990 o Banco Mundial passa a financiar inúmeros projetos de reforma educativa em vários países do mundo. Essas reformas são marcadas por mudanças na organização curricular fazendo com que o debate sobre o que ensinar e para que ensinar, alinhada a seleção de conteúdos e disciplinas, ganhe cada vez mais importância no cenário nacional.

O Programa de avaliação das escolas públicas do estado do Rio de Janeiro é um conjunto de políticas que nasce neste contexto, iniciado durante o primeiro governo do presidente Fernando Henrique Cardoso (1994/1998), estruturados em políticas já colocadas em vigor desde a nova Lei de Diretrizes e Bases da Educação (LDB). O quadro que segue mostra cronologicamente o conjunto de medidas, de caráter institucional, que a educação brasileira sofreu e sofre desde a criação da LDB.

\section{Quadro 1}

Cronologia de documentos das reformas educacionais

\begin{tabular}{|c|}
\hline LDB - 1996 \\
ENC - Provão (1996) a 2003) Enad (2004) \\
PCN`s - 1996 \\
PCN`s - 1997 \\
Fundef - 1998 \\
ENEM - 1998 \\
DCN`s - 2002 \\
Prova Brasil 2005 \\
Orientações Curriculares 2004 \\
Orientações Curriculares - 2006 \\
PDE - 2007 \\
Provinha Brasil -2007
\end{tabular}

No conjunto, todas essas reformas, apresentam dois pilares que irão orientar os novos rumos da educação brasileira: novos currículos e diretrizes curriculares (PCNs, DCNs e orientações curriculares) e novas formas de avaliação (provão, prova, provinha) cujo único objetivo é o de implantar um novo modelo de educação com vista a uma nova forma de organização e gestão do mundo do trabalho, influenciadas pelos modelos de produção flexível e de Just-in-time que prima por trabalhadores que deixam de realizar uma única tarefa por vez, com pouco treinamento de trabalho. 
Nas reformas promovidas pelo governo federal nos últimos anos, a educação e os currículos devem ser dotados de maior integração entre as disciplinas, capazes de formar habilidades e competências mais complexas e essências aos novos processos produtivos. Os novos métodos de trabalho necessitam de trabalhadores dotados de habilidades para executar múltiplas tarefas para as quais há a necessidade de treinamento nos próprios locais de trabalho.

É neste contexto de transformações das estruturas políticos-econômicos de caráter neoliberal e de transformações do mundo da educação que se insere o documento de Reorientação Curricular que a Secretaria Estadual de Educação do Rio de Janeiro apresentou para todas as escolas da rede pública, no ano 2005.

A partir deste momento, faremos um breve exercício de como o neoliberalismo, em linhas gerais, direciona as reformas na educação brasileira, fazendo um contraponto com sua versão fluminense - O Programa Nova Escola.

Nesse sentido, analisaremos os discursos e as intencionalidades do documento de Reorientação Curricular dentro do contexto do Programa Nova Escola, programa este que surgiu no Estado do Rio de Janeiro, durante a gestão do governo de Anthony Garotinho, e que visava avaliar a escolas estaduais por produtividade e eficiência.

\subsection{Uma introdução ao neoliberalismo}

O Neoliberalismo, enquanto doutrina político-econômica, nasceu nos países centrais da Europa e América do Norte já no Pós-guerra e foi uma reação teórica e política contra o Estado intervencionista do bem-estar. Essa doutrina fundada por um grupo de economistas, historiadores e filósofos acadêmicos para solucionar as mazelas do capitalismo, surge em 1947 com a fundação do Mont Pelerin Society, que leva o nome de um spa suíço em que se reuniram pela primeira vez nome notáveis como Ludwig von Mises, Milton Friedman e o filósofo Karl Popper, além de seu líder Friderich Von Hayek.

Para Perry Anderson (1995) as idéias neoliberais surgem como um ataque contra qualquer limitação dos mecanismos de mercado por parte do Estado, denunciadas como uma ameaça à liberdade econômica e política dos indivíduos. Já David Harvey define o neoliberalismo como princípios das práticas "político-econômicas que propõe que o bem-estar humano pode ser melhor promovido liberando-se as liberdades e capacidades empreendedoras individuais no âmbito de uma estrutura institucional caracterizada por 
sólidos direitos a propriedade privada, livres mercados e livre comércio" (Harvey, 2008: 12).

O neoliberalismo, a princípio, prima por um combate ao keynesianismo com objetivo de preparar as bases de um outro tipo de capitalismo, livre de regras estatizantes cujo princípio é o livre mercado. Afinal, para o ideário neoliberal a desigualdade é um valor positivo, imprescindível, onde o Estado do Bem-Estar inviabiliza a liberdade dos cidadãos e a vitalidade da concorrência, da qual depende a prosperidade de todos. Entretanto, desde a primeira publicação neoliberal, - $O$ caminho da Servidão - de Friedrich Hayek, em $1944^{18}$, até o fim do maior ciclo de acumulação do capitalismo, conhecido como Era de Ouro, que se encerra no início dos anos 1970 o ideário neoliberal permaneceu na teoria, pois, as bases que o sustentariam não haviam sido construídas.

É com a chegada da crise de acumulação fordista em 1973, fomentada pela crise do petróleo, que os países centrais do capitalismo entraram numa grande recessão que, pela primeira vez combinaram baixas taxas de crescimento com altas taxas de inflação e levados índices de desemprego. A crise de acumulação deste período afetou diversos grupos, a insatisfação foi generalizada desde as elites e classes dirigentes até aos diversos grupos de trabalhadores. É nesta conjuntura que as idéias neoliberais ganharam um grande terreno para sua efetivação (Anderson, 1995 Harvey, 2008).

Para os intelectuais neoliberais, as raízes da crise de 1973, estavam localizadas no aumento dos gastos sociais por parte do Estado, nos sindicatos e no movimento operário, que, com suas pressões reivindicativas sobre os salários inviabilizavam as bases de acumulação capitalista.

Esses processos reduziam os lucros das empresas e desencadeavam movimentos inflacionários que geravam a crise. A solução apontada pelos neoliberais é explicada por Anderson (1995) da seguinte maneira.

Manter um Estado forte, sim, em sua capacidade de romper com o poder dos sindicatos e no controle do dinheiro, mas parco em todos os gastos sociais e nas intervenções econômicas. A estabilidade monetária deveria ser a meta suprema de qualquer governo. Para isso seria necessária uma disciplina orçamentária, com a contenção dos gastos com bem estar, e a restauração da taxa "natural" de desemprego, ou seja, a criação de um exército industrial de reserva de trabalhadores para quebrar os sindicatos. Ademais, reformas fiscais eram imprescindíveis, para incentivar os

\footnotetext{
18 (Anderson; 1994. Gentili; 1996. Harvey: 2008).
} 
agentes econômicos. Em outras palavras, isso significa redução de impostos sobre os rendimentos mais altos e sobre as rendas. (Anderson, 1995: 11)

Para os neoliberais o crescimento retornaria quando a estabilidade monetária estivesse concretizada. Uma estabilidade paga pelos trabalhadores na redução dos salários, no aumento de impostos e na redução das conquistas sociais (fim do Estado do Bem-Estar). Entretanto, a hegemonia deste programa levaria toda uma década para se concretizar nos países centrais e, para que ela ocorresse por completo seria necessária a construção das bases de sustentação do projeto neoliberal.

Gentili (1996) destaca a importância teórica e política de entender o neoliberalismo como um complexo processo de construção hegemônica. Para este autor, a construção hegemônica de poder se implementa em dois sentidos articulados. $\mathrm{O}$ primeiro ocorre através de um conjunto de reformas concretas no plano econômico, jurídico, político, educacional, etc. e, o segundo, se dá por um conjunto de estratégias sociais e culturais orientadas a impor novos diagnósticos acerca da crise e construir novos significados sociais com objetivo de legitimar as reformas.

Para este autor, compreender o projeto hegemônico neoliberal é buscar a compreensão de como o mesmo impôs ao mundo uma intensa dinâmica de mudança material e, ao mesmo tempo, uma não menos intensa dinâmica de reconstrução discursivo-ideológica da sociedade. Os governos neoliberais não apenas transformaram materialmente a realidade econômica, política e social, como também conseguiram que essa transformação fosse aceita como a única saída possível para a crise de acumulação capitalista.

Isso é percebido nos discursos neoliberais que passaram a afetar amplamente os modos de pensamento que incorporou às maneiras cotidianas de muitas pessoas interpretarem viverem e compreenderem o mundo. Esses discursos neoliberais tornaram-se hegemônico por várias esferas da sociedade.

O neoliberalismo conseguiu impor os programas de ajustes na economia capitalista dos países centrais e, posteriormente, na periferia do sistema, porque sempre buscou criar uma conexão entre os programas de ajustes e a construção de um novo senso comum, a partir do qual as maiorias começam a aceitar as receitas elaboradas pelas tecnocracias neoliberais como explica Gentili (1996). 
Desde muito cedo, os intelectuais neoliberais reconheceram que a construção desse novo senso comum (ou, em certo sentido, desse novo imaginário social) era um dos desafios prioritários para garantir o êxito na construção de uma nova ordem regulada pelos princípios do livremercado e sem a interferência sempre perniciosa da intervenção estatal. Não se trata só de elaborar receitas academicamente coerentes e rigorosas, mas, acima de tudo, de conseguir que tais fórmulas fossem aceitas, reconhecidas e exigidas pela sociedade como a solução natural para antigos problemas estruturais (Gentili, 1996: 12)

O senso comum criado pelo ideário neoliberal consiste na construção de um discurso consensual de que à intervenção do Estado e à esfera pública residem todos os males sociais e econômicos e atribui à livre iniciativa todas as virtudes que podem conduzir à regeneração e a recuperação da democracia, da economia e da sociedade. Corrupção, ineficiência e desperdício são atribuições do Estado e das políticas públicas, já a eficiência e a qualidade são atribuições da livre iniciativa.

Na mesma linha de Pablo Gentili que afirma que o neoliberalismo necessita criar uma intensa mudança de ordem material e uma intensa dinâmica de reconstrução discursivo-ideológica da sociedade, Tomaz Tadeu da Silva (1994) afirma que:

O que estamos presenciando é um processo amplo de redefinição global das esferas social, política e pessoal, no qual complexos e eficazes mecanismos de significação e representação são utilizados para criar e recriar um clima favorável à visão política liberal. O que está em jogo não é apenas uma reestruturação neoliberal das esferas econômica, social e política, mas uma redefinição das próprias formas de representação social e significação social. (Silva, 1994: 13)

Todas as transformações de ordem material que o neoliberalismo necessitava para fincar suas raízes nas esferas, social, política e econômica foram encontradas na crise estrutural do regime de acumulação fordista que, no final dos anos de 1970, criou oportunidades para ascensão de inúmeros governos com este propósito.

Nos países centrais, o primeiro governo com propósito neoliberal foi o de Margareth Thatcher, em maio de 1979, na Inglaterra. A primeira ministra inglesa tinha como tarefa restringir o poder dos sindicatos e levar ao fim uma estagnação econômica inflacionária. Posteriormente vieram os governos de Ronald Reagan, nos Estados Unidos em 1980; e o de Khol, na Alemanha em 1983. O Governo do Presidente Reagan tinha o objetivo de criar políticas destinadas "a restringir o poder do trabalho, 
desregular a indústria, a agricultura e os setores extrativistas, assim como liberar os poderes das finanças tanto internamente como no cenário mundial" (Harvey, 2008: 11).

Após ser implantado, em vários dos países centrais europeus nos anos de 1980, o ideário neoliberal se ampliou para o leste da Europa, após a derrocada do socialismo soviético e os regimes chamados de comunistas da Europa Oriental. Sobre essa onda neoliberalizante, (Harvey, 2008) afirma que quase todos os Estados recém-criados após o colapso da União Soviética às socialdemocracias e Estado do Bem Estar Social ao velho estilo, como Nova Zelândia e Suécia, adotaram, às vezes voluntariamente e em outros casos em resposta a pressões coercivas, alguma versão da teoria neoliberal.

Por fim, como numa terceira grande onda, o ideário neoliberal chega à América Latina bem mais experimentado e sedimentado, através de um conjunto de políticas de reajustes macroeconômico denominado de "Consenso de Washington". Nesse continente, o neoliberalismo buscou substituir o modelo de desenvolvimento econômico baseado num conjunto de políticas denominadas de "substituição de importações", que promoveram o desenvolvimento da indústria nacional mediante a concessão de subsídios e de criação de barreiras tarifárias.

A partir de 1992 uma onda de privatizações atingiu a economia mexicana e como não poderia deixar de ocorrer, esta mesma onda também chegou ao Brasil, no início do mesmo período com o governo conservador de Fernando Collor de Melo, eleito com o objetivo de implantar o ideário neoliberal, e a cartilha do "Consenso de Washington".

Entretanto, é com um outro Fernando, o Fernando Henrique Cardoso, político proveniente de um partido social-democrata que construiu uma coligação com um partido de extrema direita, que a onda neoliberal ganha impulso e força para concretizar nas bases da sociedade brasileira toda a sua retórica.

Em todas as partes do mundo, em que o neoliberalismo se implantou o receituário foi sempre o mesmo, guardando a especificidade de cada lugar e região, redução do tamanho do Estado ("Estado Mínimo" para os serviços prestados à população), um profundo programa de privatizações de empresas estatais e empresas de serviços públicos, e um ataque impiedoso as conquistas dos trabalhadores e dos sindicatos. Entretanto, para que todo esse receituário ocorra o Estado deve cumprir um novo papel, deve se reestruturar para poder dinamizar os agentes econômicos e financeiros. 
Harvey (2008), sobre o papel do Estado neoliberal, afirma que este deve criar e preservar uma estrutura institucional apropriada a manter e regular as práticas que garantam a propriedade privada e a manutenção dos livres mercados e livre comércio. $\mathrm{O}$ papel do Estado neoliberal é a de garantir a qualidade e integridade do dinheiro, estabelecer as estruturas e funções militares, garantir direitos de propriedades individuais e o funcionamento apropriado dos mercados. Além disso, se não existirem mercados em determinadas áreas como, a terra, a água, instrução, a saúde, a segurança social e a poluição ambiental esses devem ser criados se possível pela ação do Estado. Ainda segundo Harvey, as intervenções nos mercados, pelo Estado, devem ser mantidas num nível mínimo, já que o mesmo não possui informações suficientes para entender os sinais do mercado (preços) e porque poderosos grupos de interesses vão distorcer e viciar as intervenções do Estado em seu próprio benefício.

\subsection{Neoliberalismo e o Banco Mundial}

Desde a sua criação, em 1944, na conferência de Bretton Woods, o Banco Mundial tem passado por inúmeras transformações. No pós-guerra, junto com o FMI, foi um dos organismos responsáveis a dar maior estabilidade à economia mundial, seu objetivo era de financiar a reconstrução das economias destruídas pela guerra. Posteriormente, ao longo dos anos de 1950 e 1960 o Banco Mundial ganha um perfil de financiador do desenvolvimento econômico dos países periféricos, principalmente em infra-estrutura de energia, telecomunicações e transportes.

Entretanto, foi a partir dos anos de 1980 com a eclosão da crise de endividamento das economias periféricas, principalmente aquelas situadas na América Latina, que o Banco Mundial ganhou um novo perfil, como explica Soares (1994).

(...) o Banco Mundial ganhou estratégia na reestruturação econômica dos países em desenvolvimento por meio dos programas de ajuste estrutural. De um banco de desenvolvimento, indutor de investimento, O Banco Mundial tornou-se o Guardião dos interesses dos grandes credores internacionais, responsáveis por assegurar o pagamento da dívida externa e por empreender a reestruturação a aberturas dessas economias, adequando-as aos novos requisitos do capital globalizado (Soares, 1994: 20-21)

Assim, o Banco Mundial deixou de ser somente um banco de investimentos, e passou a ampliar seus horizontes com intuito de ser, também, um organismo multilateral 
que formula e direciona políticas internas dos países em desenvolvimento influenciando na própria legislação desses países.

O Banco Mundial, em conjunto com o FMI, torna-se um organismo responsável não só pela gestão da crise de endividamento dos países em desenvolvimento, mas, também, pela reestruturação neoliberal dos mesmos. Sem o seu aval e o aval do FMI, todas as fontes de crédito internacional são fechadas aos países que descumprirem suas determinações e o receituário neoliberal.

Soares (1994), explica que é por intermédio do programas de ajuste estrutural (SAPs) que o Banco Mundial aplica o receituário neoliberal nos países em desenvolvimento, que consiste em um amplo conjunto de reformas estruturais denominadas no final dos anos de 1980 de "Consenso de Washington". Esse receituário se dá em dois momentos: o primeiro no final dos anos de 1980 e o segundo pós-crise mexicana, já em meados dos anos 90.

a) Primeiro momento das reformas estruturais (SAPs)

- equilíbrio orçamentário, sobretudo mediante a redução dos gastos públicos:

- abertura comercial, pela redução das tarifas de importação e eliminação das barreiras não tarifárias;

- liberalização financeira, por meio da reformulação das normas que restringem o ingresso de capital estrangeiro;

- desregulamentação dos mercados domésticos, pela eliminação dos instrumentos de intervenção do Estado, como controle de preços, incentivos etc.;

- privatização das empresas e dos serviços públicos

Fonte: (Soares; 1994: 27)

b) segundo momento das reformas estruturais (SAPs)

- Aprofundamento dos processos de abertura comercial, desregulamentação e privatização;

- Aumento da poupança interna, por meio de reforma fiscal (redução do gasto público, reforma tributária) e estímulo à poupança privada;

- Reforma (privatização) do sistema de previdência;

- Estímulo ao investimento privado em infra-estrutura;

- Flexibilização do mercado de trabalho (redução dos encargos previdenciários e alteração da legislação trabalhista);

- Reforma no sistema educacional;

- Implementação de programas sociais focalizados na oferta de serviços públicos para os grupos mais pobres;

- Reforma institucional e reestruturação do estado.

Fonte: (Soares; 1994: 28) 
Os quadros sintetizam de forma clara que o receituário segue o mesmo princípio, redução do tamanho Estado, privatização e redução das conquistas trabalhistas, redução dos serviços públicos e maior abertura econômica. Entretanto, é no segundo momento, que o Banco Mundial propõe a reforma no sistema educacional dos países em desenvolvimento. Mas, as estratégias dessas reformas veremos mais adiante, nas páginas desta pesquisa que descrevem as estratégias do Banco Mundial para a educação nos países em desenvolvimento.

\subsection{Neoliberalismo e educação}

Do ponto de vista da perspectiva neoliberal, os sistemas educacionais públicos, apresentam uma crise que reflete uma completa ausência de eficiência, eficácia e produtividade. O desenvolvimento dos sistemas educacionais públicos, principalmente nos países em desenvolvimento, carecem de eficiência nos serviços prestados. A crise é reflexo da ausência de "qualidade" fruto da improdutividade que caracteriza as práticas pedagógicas e a gestão administrativa na maioria das escolas públicas.

Gentili (1996) afirma que para os neoliberais os sistemas educacionais não enfrentam uma crise de democratização, mas uma crise de gerencia que provoca certos mecanismos de "iniqüidade" escolar, como evasão, repetência, analfabetismo funcional etc., e que essa crise se explica pelo caráter estruturalmente ineficiente do Estado para gerenciar políticas públicas. Somente uma reforma administrativa no sistema escolar, que promova mecanismos que regulem a eficiência, a produtividade e a eficácia pode trazer a "qualidade" aos sistemas educacionais.

O Programa Nova Escola possui no seu cerne estes princípios, pois como veremos adiante, um ponto extremamente relevante neste programa está presente no combate a evasão e a repetência, tido como prioritário e entregue cada vez mais para as unidades escolares resolverem através de uma política de gerenciamento.

Para Gentili (1996) a ausência de um verdadeiro mercado educacional em contraposição a escola estatizada permite entender a crise de "qualidade" que assola os sistemas educacionais. A estratégia do neoliberalismo consiste em transferir a educação da esfera da política para esfera do mercado transformando-a em condição de propriedade, e questionando o seu caráter de direito.

Nesse sentido a educação deixa de ser um direito de cidadania para se tornar uma mercadoria, onde os educandos passam a ser consumidores. 
Mas afinal, o que é qualidade para as políticas públicas educacionais de caráter neoliberal? Em que consiste a chamada qualidade? Por que a mesma é tão evocada pelos organismos multilaterais neoliberais?

Concordamos com Enguita $(1994,96)$ quando diz que "o predomínio de uma expressão nunca é ocioso ou neutro. A problemática da qualidade esteve sempre presente no mundo da educação e do ensino, mas nunca havia alcançado antes esse grau de centralidade". Atualmente, a questão da "qualidade", vem substituir a problemática da igualdade e a da igualdade de oportunidades.

Enguita (1994) afirma que a cada período da história da escolarização há sempre uma busca por uma melhor "qualidade" educacional. E, partindo deste princípio, esclarece como se desenvolveu o conceito de qualidade em cada momento de desenvolvimento econômico-social, na sociedade americana. Para este autor, no início do século XX, nos Estados Unidos, a qualidade foi vista dentro dos princípios da "igualdade", pois a padronização da produção e a chegada de inúmeros imigrantes em solo americano construíram uma escola que, tinha por objetivo, massificar a força de trabalho e a cultura. Já nos anos 50 e 60 a idéia de qualidade encontrava-se associada aos campos da eficiência e da igualdade porque nesse momento não bastava mais que todos estivessem escolarizados. Ganhar a concorrência bélica com os russos e obter uma vitória tecnológica no período da Guerra-fria só se fazia com "eficiência".

Já a idéia de qualidade nos sistemas educacionais do Estado do Bem-Estar estava associada à idéia de que mais recursos materiais e humanos por usuário era igual a maior qualidade. Porém, a partir dos anos 80, nos países centrais, o conceito de qualidade se deslocou dos recursos para eficácia do processo. Essa lógica já não é mais dos serviços públicos, mas da produção empresarial.

Gentili (1994) na mesma linha de Enguita (1994) afirma que a qualidade da educação vem de longa data e de que nunca como agora gozou de intenso prestigio.

Nos âmbitos pedagógicos, "qualidade" nem sempre tem tido o mesmo significado, nem seu controle feito referência aos mesmos processos. Desta forma, os diferentes paradigmas de avaliação didática e as divergentes modalidades históricas de organização curricular; as teorias (dominantes ou não) acerca do trabalho dos professores; os estudos econômicos que em suas mais variadas formas, abordam a problemática educacional, etc. sempre têm pressuposto um tipo específico de ideal de rendimento e - com ele - uma concepção - explicita ou implícita - de qualidade. (Gentili, 1994: 154-155) 
Portanto, quando se fala em qualidade hoje, se fala em subordinar a educação a lógica do mercado e da empresa flexível. A qualidade é o indicador que permite medir o grau da eficiência que é construída dentro da lógica e da análise econômica. Portanto, a noção de eficiência remete aos conceitos de competitividade e êxito.

Para concluir, essa visão de qualidade no ensino pelo entendimento neoliberal, deixa transparecer que a "qualidade" é uma questão meramente técnica baseado em "produto", do resultado educacional. Portanto, a qualidade é passível de "medição" de "padrões" que se tornam indicadores, de repetência, de evasão, de aproveitamento na aprendizagem e outros tantos mais.

\subsection{Neoliberalismo e as políticas do Banco Mundial para educação}

O Banco Mundial vem exercendo influência crescente no setor educacional, impondo a definição das políticas educativas nos países em desenvolvimento e considerando a educação um instrumento fundamental para promover o crescimento econômico e a redução da pobreza. Torres (1998) afirma que a atuação do Banco no setor vem de longa data, desde os anos 60, mas, é a partir dos anos 90 que as intervenções ganharam maior visibilidade.

Na década de 1960 o Banco Mundial atuava no setor educativo, inicialmente concedendo empréstimos que privilegiavam a estrutura física, como a construção de escolas. Posteriormente, nos anos de 1970, a ação do Banco voltou-se para a educação básica, de caráter primário, como estratégia para redução da pobreza nos países da periferia do sistema.

Essa ênfase na escola primária ganhou impulso na "Conferência Mundial sobre Educação para Todos", realizada na Tailândia, em 1990, conjuntamente com outros organismos internacionais como UNESCO, UNICEF E PNUD.

Para Rosa Maria Torres (1998), o Banco Mundial, nos anos de 1990, transformou-se na principal agência técnica em matéria de educação para os países em desenvolvimento, delineando políticas e metas a serem cumpridas por estes países.

O BM não apresenta idéias isoladas mas uma proposta articulada uma ideologia e um pacote de medidas - para melhorar o acesso, a equidade e a qualidade dos sistemas escolares, particularmente do ensino de primeiro grau, nos países em desenvolvimento. Embora se reconheça que cada país e cada situação concreta requerem 
especificidade, trata-se de fato de um "pacote" de reforma proposto aos países em desenvolvimento que abrange um amplo conjunto de aspectos vinculados à educação, das macropolíticas até a sala de aula. (Torres, 1998: 126)

Esse conjunto de propostas que o Banco Mundial trouxe para os paises emergentes, possuía no seu cerne a lógica neoliberal, os princípios do neoliberalismo onde a educação passaria a ser analisada por critérios de mercado e onde a escola seria comparada a uma empresa.

Coraggio (1998) afirma que o pacote de medidas do Banco Mundial para educação, foi elaborado tendo como princípio a teoria econômica neoclássica, onde a escola-empresa vê os processos educativos como insumos, e a eficiência e as taxas de retorno como critérios fundamentais para tomada de decisão no sistema educativo. Mas em que consiste esses insumos em educação? Vejamos o que diz Torres (1998):

A qualidade educativa, na concepção do BM, seria o resultado da presença de determinados "insumos" que intervêm na escolaridade. Para o caso da escola de primeiro grau, consideram-se nove fatores como determinantes para um aprendizado efetivo, nesta ordem de prioridades, segundo a percentagem de estudos que revelariam uma correlação e um efeito positivos (BM, 1995:51): (1) bibliotecas; (2) tempo de instrução; (3) tarefas de casa; (4) livros didáticos; (5) conhecimentos do professor; (6) experiência do professor; (7) laboratórios; (8) salário do professor; (9) tamanho da classe. (Banco Mundial apud Torres, 1998: 134)

Nesse pacote de medidas que o Banco Mundial coloca aos países em desenvolvimento, fica latente que a lógica econômica predomina antes à lógica pedagógica, pois, as mesmas, são feitas basicamente por economistas. “A relação custobenefício e a taxa de retorno constituem categorias centrais a partir das quais se define a tarefa educativa, as prioridades de investimento (níveis educativos e fatores de produção a considerar), os rendimentos e a própria qualidade" (Torres, 1998: 138).

Para o Banco altos salários para os professores e turmas com menor número de alunos oferece uma relação custo-benefício menor, ante ao número de dias escolares ou número de aulas dados, associado aos livros didáticos.

No Brasil, nas últimas décadas, o governo federal tem aumentado o número de dias letivos, investido de forma maciça em materiais didáticos através do Programa Nacional do Livro Didático (PNLD) e do recém-criado Programa Nacional do Livro 
Didático Para o Ensino Médio (PNLEM), em detrimento de uma política que valorize o magistério como carreira a ser seguida e estimulada no conjunto da sociedade.

Segundo ainda o Banco, os sistemas educativos dos países considerados em desenvolvimento devem buscar solucionar quatro grandes problemas: o acesso, a equidade, a qualidade, e a redução das distâncias entre a reforma educativa e a reforma das estruturas econômicas. Solucionar esses problemas deve ser encarado por esses países como sendo um desafio, o que demanda de cada um deles a realização de reformas educacionais urgentes.

Para Torres (1998), a ótica do Banco Mundial na reforma educativa dos países emergentes é inevitável e urgente, onde a sua negação trará sérios custos econômicos sociais e políticos. Nessa ótica, o Banco, destaca os principais pontos que formula o pacote de reformas para esses países.

Primeiro, a prioridade sobre a educação básica onde o Banco Mundial estimula os países a concentrar recursos, pois, um maior investimento nesse segmento educacional gera maiores benefícios sociais e econômicos para as populações mais pobres reduzindo, com isso as tensões sociais.

Segundo, a melhoria da qualidade e da eficiência da educação como eixo da reforma educativa. Para o Banco Mundial a qualidade encontra-se nos resultados e esses são verificados no rendimento escolar.

Terceiro, a prioridade sobre os aspectos financeiros e administrativos da reforma educativa. Nesse sentido faz-se necessário que os países emergentes reformulem a administração da educação.

Quarto, o Banco sugere uma maior descentralização das instituições escolares cujo único objetivo é torná-las autônomas pela busca dos resultados fixados, à priori, pelos governos. Nesse sentido o Banco Mundial aconselha os governos de países emergentes a manter centralizadas as seguintes funções: 1) fixar os padrões; 2) facilitar os insumos que influenciam o rendimento escolar; 3) flexibilizar o acesso a esses insumos e monitorar o desempenho escolar. E, para que os objetivos anteriores sejam alcançados torna-se necessário descentralizar as medidas financeiras e administrativas, e criar autonomia para as direções escolares e para os professores.

Quinto, maior participação dos pais e da comunidade nos assuntos escolares tendo em vista, sobretudo, como uma condição que facilitaria o desempenho da escola como instituição, a fim de criar uma relação benéfica entre escola e família pautada principalmente e um maior envolvimento na gestão escolar. A noção de participação da 
gestão na educação, segundo o Banco Mundial, está fortemente pautada no aspecto econômico.

Os outros pontos destacados são: maior impulso do setor privado e dos organismos governamentais como agentes ativos no terreno educativo, tanto na tomada de decisões como na implementação das mesmas; maior mobilização e alocação eficaz de recursos adicionais para educação de primeiro grau; um enfoque setorial; e por último a definição de políticas e prioridades baseadas na análise econômica. Nesse sentido, "o modelo econômico que nos propõe o Banco Mundial é um modelo essencialmente escolar e um modelo escolar com duas grandes ausências: os professores e a pedagogia" (Torres, 1998: 139). O ensino resume-se a um conjunto de insumos e a aprendizagem é vista como resultado previsível da presença desses insumos. Cada insumo é valorizado e priorizado ou não sob dois aspectos: sua incidência sobre aprendizagem e seu custo, conforme explica Torres.

(...) e sob estes parâmetros que é definido um conjunto de "avenidas promissoras" e "becos sem saída" para a reforma da escola de primeiro grau, priorizado, por exemplo, o livro didático (alta incidência e baixo custo) sobre o docente (alta incidência e alto custo). A capacitação em serviço sobre a formação inicial, ou o livro didático sobre a biblioteca escolar. (Torres, 1998: 140)

Em resumo, as estratégias do Banco Mundial para educação, passam sempre pela lógica do mercado neoliberal onde a lógica da educação pública tem que ser substituída pela lógica da livre iniciativa e do mercado e, para que isto ocorra, não é necessário que o sistema educacional público seja privatizado como um todo, mas que a lógica do seu funcionamento interno seja privatizado seguindo a lógica do mercado. É necessário fazer com que os professores, alunos, funcionários, pais, ou seja, toda a comunidade escolar não só pense, mas reproduza a lógica discursivo-ideológica do neoliberalismo que na escola é travestida sob o discurso da busca da "qualidade". Em suma, é a privatização do ensino na cultura da escola e sob a forma de pensar da comunidade escolar. 


\subsection{As políticas de educação do Banco Mundial para o Brasil}

Como já exposto anteriormente, o Banco Mundial, considera a educação como instrumento imprescindível de combate pela redução da pobreza, além de um poderoso instrumento que permite fomentar o crescimento econômico. No Brasil ${ }^{19}$, as políticas do Banco para educação não vão se diferenciar, em muito, das políticas que o mesmo impõe, para o conjunto dos países emergentes.

É claro que não pretendemos negligenciar o papel dos atores locais (governo e sociedade civil) no processo de apropriação de orientações internacionais e a capacidade que os mesmos têm de adaptar esse conjunto de políticas globais, criando variações hibridizadas nos contextos nacionais. Entendemos que as políticas formuladas por organismos internacionais ganham diferentes graus de intensidade nos contextos nacionais.

Nesse sentido, corroborando com a análise de que políticas educacionais formuladas por organismos internacionais ganham novas formas e pode mascarar opções feitas por governos nacionais, Lopes (2008) partindo dos estudos de Candau destaca o quanto são distintas as políticas para o ensino superior no Equador, na Bolívia e na Argentina, todas elas financiadas pelo Banco Mundial. Portanto, entendemos que se faz necessário aprofundar as análises de compreender o papel dos atores locais com os governos e sociedade civil na apropriação das orientações internacionais. O conjunto de políticas educacionais que o Banco Mundial propõe para os países da América Latina possui variações, sutilezas e nuances quando apropriadas pelos governos brasileiros.

No Brasil, a partir do final da década de 1980, os empréstimos do Banco Mundial para o setor educacional têm aumentado consideravelmente. Enquanto nos anos de 87-90 constituíram somente 2\% dos empréstimos, nos anos 91-94 chegaram a representar 29\% do total (Soares, 1998).

As estratégias desta instituição para o sistema educacional brasileiro são pensadas dentro dos preceitos neoliberais. O seu diagnóstico ressalta a baixa qualidade

\footnotetext{
${ }^{19}$ Segundo Lopes (2008), no caso brasileiro, as relações com agência de fomento, como o BID e o banco Mundial, desenvolveram-se de forma bastante estreita na vigência dos dois mandatos presidenciais de Fernando Henrique Cardoso - em virtude, também, de lideranças dessas reformas no Ministério da educação terem atuado diretamente em tais agências. Paulo Renato Souza, ex-, ministro da educação, e Guiomar Namo de Mello, membro do conselho Nacional de Educação do Ministério da Educação brasileiro e relatora do parecer sobre as Diretrizes Curriculares da Educação, foram consultores do Banco Mundial.Claudio de Moura Castro, Assessor do MEC nas reformas do ensino médio e da educação profissional, é sênior education advisor na unidade de educação do Departamento de Desenvolvimento Sustentável do BID e possui várias publicações nesta agência sobre as políticas de ensino médio.
} 
do sistema que reflete nos altos índices de repetência e evasão escolar o que gera para o os governos, elevados custos e desperdício de capital humano.

Para o Banco Mundial, conforme aponta De Tommasi (1998), os fatores que mais contribuem para a baixa qualidade e a ineficiência da educação pública no Brasil são:

a) A falta de livros didáticos e outros matérias pedagógicos;

b) A prática pedagógica inapropriada, que estimula os professores a reprovar;

c) A baixa qualidade da gestão dos sistemas educacionais.

Portanto, para equacionar os problemas apresentados pelos sistemas educacionais brasileiros, e com o objetivo de contribuir com que os estudantes alcancem uma melhor aprendizagem e reduzir as taxas de repetência, o Banco Mundial estabelece como prioritárias, no Brasil, as seguintes medidas:

a) Providenciar livros didáticos e outros materiais de ensino;

b) Melhorar as habilidades dos professores, buscando uma capacitação em serviço;

c) Elevar a capacidade de gerenciamento. (Buscar a integração entre as diversas esferas de poder - da Federal à Municipal.)

Todas as medidas apontadas pelo Banco Mundial para melhoria da educação brasileira de certa forma são fieis as orientações de ações estabelecidas pela instituição em nível mundial, entretanto, veremos mais adiante que esses conjuntos de orientações aparecem de forma explícita nas políticas que orientam o "Programa Nova Escola" no estado do Rio de Janeiro.

Também entendemos que cabe um outro paralelo do campo do currículo com as políticas que o Banco Mundial possui para educação, partindo de um artigo esclarecedor de Rosa Maria Torres (1998). Para esta autora, o Banco possui uma visão estreita sobre currículo e educação. Para os técnicos do Banco o ensino é visto pela perspectiva da visão tradicional de ensino, uma educação transmissora e "bancária", um conjunto de informações a serem assimilados como demonstra a autora.

É no âmbito curricular e pedagógico - âmbito no qual se definem e se baseia essencialmente o elemento educativo - onde se torna mais 
evidentes as fragilidades dos economistas e técnicos do BM. A própria noção de currículo que se discute e que subjaz ás propostas de política do BM é estreita, entendendo-se por currículo conteúdos (e reduzindo os conteúdos por sua vez, a disciplinas). "O currículo define as matérias a serem ensinadas e fornece um guia geral em torno à frequiência e duração da instrução" (BM, 1995: XVI) (Torres, 1998: 141).

Para o Banco Mundial, mudança curricular equivale essencialmente a mudança nos conteúdos em vez de mudanças nas formas de se fazer educação, ou seja, pensar o currículo como o centro da escola, o currículo que traz toda uma concepção de escola, de sociedade e de cidadão que se deseja formar. A concepção de currículo do Banco Mundial reforça a tradicional separação entre conteúdo e método, entre currículo e pedagogia como coloca Torres.

As definições amplas de currículo entendem como tal não somente os conteúdos, mas também os objetivos, as estratégias, os métodos e os materiais de ensino, bem como os critérios e os métodos de avaliação do referido ensino. Quer dizer, esta concepção de currículo vê como um todo inseparável o que se ensina e o que se aprende (conteúdos), o como se ensina e se aprende (relações, métodos, procedimentos, práticas), ou para que se ensina e se aprende (objetivos), e o que e como se mede aquilo que se aprende (avaliação) (Torres, 1998: 141).

O entendimento que o Banco Mundial possui de currículo é aquele exposto no início de nossa pesquisa que em grande parte é compartilhada pela grande maioria dos professores da educação básica de que currículo é, em linhas gerais, um guia curricular ou um conjunto de planos de ensino ou apenas um currículo prescrito por algum órgão seja governamental ou não.

Torres (1998) ainda afirma que o Banco Mundial colocou nas reformas educacionais dos anos 1990, uma falsa contraposição entre o currículo prescrito e o currículo efetivo (currículo real ou o currículo em ação que ocorre na sala de aula), desaconselhando as reformas curriculares empenhadas em modificar o currículo prescrito, argumentando que este procedimento gera expectativas no corpo docente e que as mesmas não se traduz, efetivamente, em melhorias dentro das escolas. Propõe que é melhor investir na melhoria dos textos escolares, considerado um currículo prescrito mais eficiente por guiar o trabalho dos professores e alunos através de conteúdos e atividades pré-estabelecidas. 
De fato, as propostas curriculares são bastante efetivadas na medida em que seus princípios são apropriados pelos livros didáticos que são os veículos, ou os textos escolares, que possuem um maior poder de transformação nas práticas dos professores. No Brasil, o livro didático vem "construindo" e sedimentando as políticas curriculares, propostas pelo MEC através dos PCNs para o ensino fundamental e médio, por meio dos seus textos, atividades e exercícios. É através do livro didático que se viabiliza as propostas mais gerais de ensino, currículo e educação. Como exemplo, temos o slogan que impresso nos livros didáticos que trazem as seguintes afirmativas - de acordo com os novos parâmetros ou de acordo com as Diretrizes Curriculares Nacionais para o ensino Médio ou novo ensino médio -, que tendem a transmitir a idéia de um padrão curricular, como se esse livro fosse o próprio currículo prescrito pelo MEC.

Por último, Torres reafirma outra preocupação do Banco Mundial com as reformas curriculares quando o mesmo recomenda, enfaticamente, que o processo de elaboração e desenvolvimento do currículo tem que ser uma tarefa restrita ao poder central ou regional, sem a participação local (participação da comunidade escolar). Entendemos que a reforma curricular da SEE-RJ segue estes princípios, mesmo quando o documento afirma o contrário, que os professores foram consultados através de um questionário e que participaram de forma efetiva através de reuniões e um Workshop.

É importante frisar e ressaltar, mais uma vez, que apesar das interferências recentes que o Banco coloca para os governos brasileiros no sistema educacional as mesmas, não ocorrem de forma homogênea, pois entendemos que existe um espaço de autonomia para os técnicos e educadores nacionais implementar políticas que sejam mais condizente com a realidade brasileira.

Para finalizar gostaríamos de afirmar que as propostas de reformas da educação que o Brasil vem sofrendo nas últimas décadas, - e o Programa Nova Escola junto com a Reorientação Curricular faz parte deste contexto -, é produto de uma mesma lógica que como afirma Porto-Gonçalves (1999), indica que estamos diante de propostas que se colocam em escala supranacional e, assim, a sua territorialidade se coloca numa escala planetária.

Esse fato, por seu turno, nos remete a protagonistas que se colocam nessa escala política de ação. É o mesmo espírito que vem comandando as mesmas propostas nos mais diferentes países, revelando que eles não emanam dessas diferentes realidades sócio-culturais e geográficas que são os estados nacionais. Se até aqui o processo de 
internacionalização vinha se fazendo, sobretudo no campo da economia, com as propostas de reformas no mundo da educação vemos um aprofundamento desse processo que, através da educação, tenta se colocar as condições gerais de produção subjetiva (de que a educação é pressuposto) para um salto de acumulação do capital. (PortoGonçalves, 1999: 74).

Sendo assim, para que o processo de acumulação do capital no atual estágio de desenvolvimento se perpetue, faz-se necessário que a lógica do mercado, da competitividade, da eficiência e qualidade, também se perpetue na escola e no ensino, não apenas nas escalas globais e nacionais, mas, também, nas escalas locais. E o "Programa Nova Escola", versão local das reformas globais, encontra-se inserido nesse jogo escalar, - global/nacional/local.

Nas próximas páginas, desta dissertação, buscamos mostrar como o "Programa Nova Escola" da SEE-RJ, traz no seu cerne a lógica do mercado, pois, além de ter como metas a busca pela eficiência, gestão e produtividade que formulam o conceito de qualidade neoliberal, foi o único programa educacional no Brasil que atrelou a busca por essas metas ao salário dos professores, gratificando-os desigualmente em função da avaliação de cada escola.

\subsection{O Programa Nova Escola.}

O programa Estadual de Reestruturação da Educação Pública - "Programa Nova Escola" - foi instituído pelo decreto do Governo do Estado do Rio de Janeiro n ${ }^{\circ}$ 15.959 de 12 de janeiro de 2000, durante a gestão do governo Anthony Garotinho, que contratou sem licitação a Fundação Cesgranrio para a realização do processo de avaliação externa. Segundo o decreto, o Programa Nova Escola compreende o Sistema Permanente de Avaliação das Escolas da Rede Pública Estadual de Educação, abrangendo os seguintes aspectos:

I - Gestão Escolar, compreendendo: Gerenciamento de Recursos Humanos; Aplicação dos Recursos Financeiros; Infra-estrutura Física; Programa de Nutrição Escolar e Integração da Escola com a Comunidade.

II - Processo Educativo abrangendo: Evasão escolar; Aproveitamento escolar e repetência; Distorção idade-série; Universalização do acesso; Atendimento aos portadores de necessidades especiais; Política de leitura; Inovações pedagógicas; Uso de novas tecnologias 
educacionais; Tempo de permanência do aluno e professor na escola; Formação continuada; Participação dos pais no processo educativo e Articulação da escola com os equipamentos de saúde, lazer e cultura do bairro ou da cidade (Leal; 2004 apud Diário Oficial do Rio de Janeiro, 12/01/2001).

Ao longo dos anos de 2000, 2001 e $2003^{20}$, a Fundação Cesgranrio executou a avaliação externa da qualidade das escolas estaduais, utilizando como critério, três aspectos: gestão escolar, indicadores de eficiência (repetência, evasão, distorção idadesérie) e desempenho escolar dos alunos. Nestes três aspectos avaliativos, estavam incluídos os 17 critérios acima citados que posicionavam as escolas em cinco níveis de desempenho.

Esse programa em linhas gerais visava criar um sistema de avaliação das escolas estaduais do estado do Rio de Janeiro e, a partir de então, criar um ranking entre as mesmas. O objetivo final deste ranking era o de conceder gratificações diferenciadas aos professores e funcionários lotados nas escolas. Essa vinculação entre avaliação e concessão de gratificações calcava-se tanto em uma concepção meritocrática de escola pública quanto na tentativa de deflagrar um processo de competição entre os profissionais nela envolvidos. Najjar (2004, 27) afirma que "programas como esse, realizados no bojo de reformas de cunho neoliberal em educação, tentam realizar transformações tanto de caráter organizativo quanto de caráter ideológico”.

De forma geral, o governo do estado procurava demonstrar para a sociedade que este programa valorizava o magistério e que a questão salarial estava posta sob controle dos professores, funcionários e diretores das unidades escolares, pois era só cumprir as metas estabelecidas pela secretaria de educação que os salários de todos elevariam-se substancialmente.

Como exposto anteriormente, o objetivo do "Programa Nova Escola" não era o de, simplesmente, avaliar, mas sim, de classificar as escolas criando um ranking entre as mesmas. Depois de classificadas os servidores em efetivo exercício em qualquer das unidades da rede pública estadual de educação receberiam uma gratificação específica de desempenho da escola, classificada pelo Grau de Desempenho de acordo com níveis, que variavam de I a V. Ou seja, as gratificações, nos 5 primeiros anos do Programa,

\footnotetext{
${ }^{20}$ No ano de 2002 não houve avaliação do Programa Nova Escola, já que o Governo de Benedita da Silva que assumiu o comando do estado por nove meses, acatou o pedido do Sindicato Estadual dos Profissionais de Ensino ( SEPE) pelo fim do programa.
} 
variavam de $R \$ 100,00$ a $R \$ 500,00$ para professores e $R \$ 50,00$ a $R \$ 250,00$ para pessoal de apoio. Veja a tabela.

Quadro 2

Tabela de Gratificação - Programa Nova Escola

\begin{tabular}{|c|c|c|}
\hline $\begin{array}{c}\text { GRAU DE } \\
\text { DESEMPENHO DA } \\
\text { ESCOLA }\end{array}$ & $\begin{array}{c}\text { GRATIFICAÇÃO PARA } \\
\text { PROFESSORES }\end{array}$ & $\begin{array}{c}\text { GRATIFICAÇÃO PARA } \\
\text { FUNCIONÁRIOS }\end{array}$ \\
\hline NIVEL I & $\mathrm{R} \$ 100,00$ & $\mathrm{R} \$ 50,00$ \\
\hline NÍVEL II & $\mathrm{R} \$ 200,00$ & $\mathrm{R} \$ 100,00$ \\
\hline NÍVEL III & $\mathrm{R} \$ 300,00$ & $\mathrm{R} \$ 150,00$ \\
\hline NÍVEL IV & $\mathrm{R} \$ 400,00$ & $\mathrm{R} \$ 200,00$ \\
\hline NÍVEL V & $\mathrm{R} \$ 500,00$ & $\mathrm{R} \$ 250,00$ \\
\hline
\end{tabular}

(Najjar, 2004: 83)

Para Najjar (2004) além do programa de avaliação das escolas possuir um caráter classificatório, esse mesmo programa buscava promover entre as mesmas um aspecto de competição. A busca da melhoria da qualidade das escolas seria assim, basicamente, fruto da competição entre elas. Afirma ainda, que a desigualdade não seria coisa a ser temida, mas incentivada. Pois, da desigualdade nasceria um processo "sadio" de competição que resultaria na melhora da qualidade da educação de todo o sistema e utiliza para ilustrar essa competição a seguinte situação.

Tal processo pode ser comparado a uma cena de um filme "hollywoodiano" de pouca expressão (Linha Mortal), em que, em uma faculdade de medicina, a professora explica seus critérios de avaliação, dizendo que, em função das provas, distribuiria pelos alunos da turma uma nota dez e três ou quatro notas oito. Os que não obtivessem essa nota teriam ou a nota mínima de aprovação ou seriam reprovados. A mensagem que estava implícita e que a personagem da professora logo depois explicita é a de que o importante naquele processo não era conhecer o que cada um sabia ou não sabia. $\mathrm{O}$ importante era cria um mecanismo que levasse os alunos a se superarem. (Najjar, 2004: 81).

Jorge Najjar afirma ainda que "a comparação da cena acima descrita com o que ocorre no Programa Nova Escola parece ser ainda mais adequada quando vemos que na 
primeira classificação, realizada em 2000, nenhuma escola - das quase duas mil da rede - conseguiu alcançar o nível V, o mais alto previsto” (Najjar, 2004: 82).

Quadro 3

Ranking das escolas

\begin{tabular}{|c|l|l|l|}
\hline Ranqueamento & 2000 & 2001 & 2003 \\
\hline NIVEL I & 55 escolas & 1 escola & 955 escolas \\
\hline NÍVEL II & 1505 escolas & 416 escolas & 808 escolas \\
\hline NÍVEL III & 261 escolas & 1039 escolas & 96 escolas \\
\hline NÍVEL IV & 98 escolas & 400 escolas & 5 escolas \\
\hline NÍVEL V & 0 escolas & 24 escolas & 0 escolas \\
\hline
\end{tabular}

(Najjar, 2004: 83)

É interessante observar que no ano de 2001 o maior número de escolas encontrava-se no nível III e apenas uma no nível I. Já o ano de 2002 não aparece no gráfico já que não houve avaliação durante os nove meses de governo de Benedita da Silva, do Partido dos Trabalhadores. A Avaliação não ocorre neste período porque este governo "tampão"21 acata o que os professores, representados e mediados pelo SEPE, reivindicavam - a extinção do Programa.

Foi neste ano que ocorreram grandes manifestações e greves por parte dos profissionais do ensino, que denunciavam os verdadeiros objetivos do Programa: não cumprir o plano de carreira dos professores, plano este que valorizava os docentes por formação e tempo de serviço e atribuir os altos índices de evasão e repetência, além das deficiências de aprendizagem somente a cargo dos professores, isentando o Estado e os governos de responsabilidades.

Entretanto, nas eleições para o governo do Estado do RJ, Benedita da Silva saiu derrotada. Sua principal oponente e sucessora de Anthony Garotinho, Rosinha Garotinho, vence, logo no primeiro turno, e esta quando assume afirma que não pagaria as gratificações do programa por não ter ocorrido a sua avaliação no governo anterior. Essa medida provocou um grande prejuízo aos professores que ficaram com uma

\footnotetext{
${ }^{21}$ O Governo de Benedita da Silva teve a duração de apenas 9 meses, se estendendo até o dezembro de 2002. Isto ocorreu devido a necessidade do seu antecessor,o governado Anthony Garotinho, ter que deixar o cargo para concorrer à presidência da República naquele ano.
} 
quantia bem menor em seus salários já que a grande maioria das escolas encontrava-se nos níveis II, III e IV como demonstra a tabela.

Para muitos, professores, SEPE e oposição, esta medida foi tomada devido aos ganhos salariais que os professores obtiveram no governo Benedita da Silva com o descongelamento de plano de cargos e salários dos professores concedidos pela justiça. Esse plano há muitos anos não vinha sendo pago, pois segundo os governos, o plano de cargos e salário dos professores onerava a folha de pagamentos e consumia inúmeros recursos.

O plano de carreira dos professores possui nove níveis e a cada nível o professor recebe $12 \%$ sobre o vencimento básico. Um professor docente II quando inicia sua carreira no Estado, encontra-se, imediatamente relacionado no nível III - ou seja, recebe um valor $36 \%$ acima do vencimento básico. A partir de então, continua progredindo um nível a cada cinco anos ou, mais um nível, por titulação - especialização, mestrado, e doutorado. Percebe-se que é um plano de carreira cujo objetivo principal é o de tornar a questão salarial independente da atuação dos governos. Para muitos, o Programa Nova Escola, como já mencionado anteriormente, tinha como principal objetivo atacar o plano de carreira dos docentes e de responsabilizar os mesmos pelo fracasso das políticas públicas em educação ou, pelo menos, uma boa parte dos problemas. É o que deixa claro um dos panfletos do SEPE no ano em que o "programa Nova escola" foi implantado.

O governo usa a lógica de culpar os profissionais pelos problemas da escola. O governo, supostamente, já estaria fazendo a sua parte, garantindo condições iguais para todas as unidades da sua rede, de modo que elas já estariam aptas para serem "avaliadas" com base nos critérios criados pelo Nova Escola. O que orienta o projeto do governo em momento algum é a visão pedagógica do processo educativo, mas sim, a visão econômica da necessidade de "enxugamento" da máquina e da diminuição das despesas de setores fundamentais. O governo tem necessidade de apresentar ao Banco Mundial índices baixos de analfabetismo, evasão e repetência e gera esta política que tenta vincular os salários dos profissionais de educação a um desempenho que será medido por tais índices. Não defendemos a reprovação, mas também não podemos compactuar com esse processo (Leal apud SEPE, 2000).

O governo estabeleceu uma "nova" concepção para a ascensão na carreira e, na prática, rasgou o plano de carreira onde a ascensão se dava basicamente pelo tempo de serviço e pela formação (SEPE, 2000).

O governador mantém o arrocho e ignora o Plano de Carreira como estratégias para assegurar a pressão econômica sobre a categoria. A avaliação é o golpe final para a criação de uma verdadeira competição 
entre as escolas estaduais. Tudo em nome da famigerada produtividade (SEPE/CUT/CNTE,2000 apud Leal 2004).

Por outro lado, entendemos que o sentido do plano de carreira dos professores do estado do Rio de Janeiro reflete uma outra lógica subjacente à lógica neoliberal. Pois o atual plano de carreira valoriza a formação do professor e o tempo de serviço prestado ao longo da sua carreira. Já um plano de carreira dentro da lógica neoliberal (se é que pode existir plano de carreira nos preceitos neoliberais) busca priorizar outros aspectos como o de produtividade e eficiência, como manda a "cartilha" dos organismos internacionais como o Banco Mundial, ou seja, não há ganho salarial por tempo de serviço mas, por "melhores resultados" de metas pré-estabelecidas.

Os salários dos docentes, com o retorno do plano de carreira, elevaram-se substancialmente no segundo semestre de 2001. Todos ganhavam como vencimento básico $\mathrm{R} \$ 416,00$ e a partir de então, cada nível acima criou, automaticamente, um reajuste de $12 \%$ sem contar com a incidência dos triênios. Para os professores e sindicato foi essa a justificativa principal, a de não continuar pagando as gratificações do Programa Nova Escola em 2002 e se havia alguma dúvida de que o Programa Nova Escola não era uma política salarial, o que afirmava constantemente a governadora Rosinha Garotinho, essa dúvida dissipou-se para os servidores da educação. É a lógica de aproveitamentos de insumos com baixo custo e alta incidência que e prioritária em governos neoliberais. Professores com altos salários e bem formados possuem elevados custos e grande incidência, portanto este "insumo" não é prioritário no Programa Nova Escola e nos governos de Rosinha e Garotinho.

O fato, é que, a partir de 2003, nenhuma escola ganhou uma gratificação no valor de $\mathrm{R} \$ 500,00$ e em 29 de abril de 2004 é publicado o decreto 35.292 que alterava os critérios para a gratificação específica de desempenho das unidades escolares, instituída pelo decreto 25.959 .

Este decreto mudava a forma de avaliação do "Programa Nova Escola", porém não a sua essência que era a de classificar e ranquear. Pelo contrário o decreta buscava aumentar, de forma significativa, a competição entre as escolas.

Outra característica importante deste decreto é a divisão da avaliação do programa em duas partes: (1) A avaliação da escola e (2) a avaliação do progresso da escola. Vejamos como o decreto busca direcionar essa nova forma de avaliação. 
Art. $2^{\circ}$ Dos artigos financeiros destinados ao pagamento da gratificação por desempenho de que trata o artigo $1^{\circ}$ deste Decreto, a metade será rateada, proporcionalmente, entre os servidores lotados nas Unidades Escolares, segundo os níveis por elas obtidos, em conformidade com o previsto do Anexo I do presente Decreto.

$\S 1^{\mathrm{o}}$ - Os professores, lotados em uma Unidade Escolar classificada no nível $\mathrm{V}$, receberão uma gratificação 5 (cinco) vezes maior que a conferida aos professores lotados na Unidade Escolar de nível I; os lotados na de nível IV , 4 (quatro) vezes maior; os lotados na de nível III, 3 (três) vezes maior; os lotados na de nível II, 2 (duas) vezes maior do que a gratificação conferida aos professores lotados na unidade escolar de nível I.

Art. $3^{\text {o }}$ - A outra metade dos recursos financeiros destinados ao pagamento da gratificação será rateada entre os servidores das Unidades Escolares que, em duas avaliações anuais e sucessivas, obtiverem aumento em seus índices médios finais, em conforminadade com o previsto no Anexo II do presente Decreto.

$\S 1^{\circ}$ - As Unidades Escolares que registrarem aumentos, conforme estatuído no caput do presente artigo, serão relacionadas numa tabela de Escalonamento a ser publicada pela Secretaria de Estado de Educação em ordem classificatória, decrescente por índices médios finais e serão distribuídas em 5 (cinco) segmentos de modo que cada um tenha o mesmo número de escolas.

O decreto, em seu artigo segundo, busca dar maior ênfase ao processo de competitividade entre as escolas. A partir deste momento, a metade do montante dos recursos passa a ser distribuído na avaliação externa das escolas (avaliação da escola). O volume de recursos passa a ser constante, ou seja, o bolo é único para todos, mas repartido de forma desigual onde o nível 5 ganha cinco vezes mais que o nível 1. Esse mecanismo é bastante diferente do anterior que pagava $R \$ 500,00$ ao nível 5 e $R \$ 100$ ao nível 1 independente do número de escolas que obtivessem tais colocações.

Mas em que consiste esta avaliação externa? Quais são os indicadores utilizados como critérios?

Vejamos, os indicadores utilizados como critérios são: 1) avaliação do aprendizado, 2) avaliação do fluxo escolar e 3) gestão escolar.

No primeiro critério, a avaliação do aprendizado, consiste em uma avaliação que busca quantificar o desempenho dos alunos em uma prova de matemática e língua portuguesa. Já o segundo, avaliação do fluxo escolar consiste em reduzir os índices de reprovação e evasão na escola e o último, a avaliação da gestão escolar, mais restrita ao papel das direções escolares, no trato com os recursos humanos e financeiros da escola. 
Já o artigo três do Decreto aponta que o outro montante da gratificação passaria ser distribuído comparando o desempenho da Unidade Escolar com o seu desempenho na avaliação anterior (avaliação do progresso da escola). Se os índices, da unidade escolar avançam a gratificação é maior (dentro da limitação orçamentária), se os índices recuam a gratificação é menor. Em suma, as metas precisam avançar ano a ano onde os índices de aprendizado têm que aumentar, a evasão e reprovação diminuir e os recursos humanos e financeiros utilizados precisam ser geridos de forma mais eficiente (essa eficiência consiste em redução de gastos e prestação de contas adequada à lógica empresarial).

É importante frisar que os índices possuem pesos diferenciados. Avaliação da aprendizagem e avaliação do fluxo escolar representa $80 \%$ do total da avaliação $(40 \%$ para cada item) e gestão escolar representa, apenas, $20 \%$ do total.

Em resumo, a partir do decreto 35.292, as Unidades Escolares, dentro do Programa Nova Escola, passaram a ter três metas a serem cumpridas. A primeira meta era a de assegurar aos alunos da educação básica o desenvolvimento de competências fundamentais para a continuidade de seus estudos e a plena integração na sociedade contemporânea. A segunda meta dizia respeito à permanência do aluno na escola diminuindo os índices de reprovação e evasão. Já a última meta dizia respeito ao padrão da gestão escolar, ou seja, como são tratados os recursos humanos e financeiros que a escola dispõe. Por último a escola era avaliada no seu progresso ou regresso em relação ao cumprimento das metas. E a partir de então o professor passava a receber duas gratificações.

Permanência na escola, aproveitamento escolar e eficiência na gestão, para um número significativo de professores, não se poderia questionar o alcance dessas metas, pois deveriam ser os objetivos de qualquer rede pública de ensino e escola. Entretanto, sabemos que essas metas não são "vazias" ou desprovidas de significados. O que o Programa Nova Escola buscava é o princípio das propostas liberais para educação, - a busca da qualidade total -, e essa qualidade tem que vir a ser alcançada pela lógica gerencial apresentada pelo Banco Mundial, redução de custos e maior eficiência.

A eficiência é sinônimo de qualidade no Programa Nova Escola que somente pode ser verificado pela medição, pelos indicadores, que vão aparecer no produto final. Esse produto consiste em um pacote e no seu interior a essência que consiste em menor repetência e menor evasão, logo maior aprovação e, por conseguinte, menores custos, tudo na lógica empresarial ante a lógica pedagógica. 
Essa lógica empresarial, que se encontra no cerne do Programa Nova Escola, reduz o papel do Estado transferindo suas atribuições e responsabilidades, como resolver a questão da evasão e dos altos índices de reprovação ou, a carência de infraestrutura, às unidades escolares e deixando a cargo do poder público a formulação das políticas de controle.

Sabemos que, em grande parte, o elevado índice de evasão na rede pública estadual deve-se a questões externas à escola. Os alunos evadem por motivos inúmeros como a busca pelo emprego, a jornada de trabalho elevada, as horas extras de final de ano no comércio (uma grande maioria trabalha no setor de serviços), a violência em comunidades dominadas pelo tráfico de drogas que cria um horário de entrada e saída das mesmas restringindo a circulação das pessoas e logo o acesso à escola. Todos esses fatores são externos às escolas onde os profissionais da educação possuem recursos limitados à sua interferência.

Entretanto, parece que o governo do estado, neste momento, procura aperfeiçoar os mecanismos de avaliação do Programa Nova Escola e avançar nas políticas que fundamentam este Programa.

Neste segundo momento, a lógica neoliberal prescrita pelo Banco Mundial, fica cada vez mais transparente. O salário é cada vez mais atrelado à lógica da produtividade, o plano de carreira dos professores é neutralizado via congelamento nos seus vencimentos e os reajustes, somente ocorrem (ou quando ocorrem) nas gratificações que são pagas pela produtividade da escola.

Outra característica importante do Programa Nova Escola é o seu processo de construção que ocorre através de um conjunto de políticas implementadas pelo governo do estado na qual chamamos de descentralização centralizada ${ }^{22}$. Esse conjunto de políticas é centralizado porque o Estado cria um conjunto de diretrizes gerais, na esfera estadual, a serem implementadas pelas unidades escolares e ao mesmo tempo, descentraliza os recursos dando uma maior autonomia às escolas para definir suas prioridades, como gastos com manutenção e pequenas reformas, compra de merenda,

\footnotetext{
${ }^{22}$ Este termo foi utilizado pela professora Maria de Encarnação Beltrão Sposito para caracterizar os traços essenciais da política educacional brasileira durante a gestão do presidente Fernando Henrique Cardoso que centralizou as diretrizes gerais da educação brasileira no período de seu governo e, ao mesmo tempo aumentou as responsabilidades dos estados e dos municípios na implantação e gerenciamento dessa política educacional. Segundo a autora, "a descentralização centralizada pode ser justificada, na medida que a descentralização quanto mais intensa ela for, exigiria diretrizes gerais básicas, de forma a garantir o mínimo de qualidade e equivalência nacional no ensino que se pratica em todo o país ou, em outras palavras, uma política de centralização das decisões e parâmetros gerais que conduziriam a descentralização". (1999: 21).
} 
contratação de pessoal e etc. Porém toda esta autonomia passa a ser avaliada pelo programa segundo suas normas, regras e padrões, onde, por exemplo, a compra de merenda tem que ser efetuada nas empresas cadastradas pela SEE-RJ ou ainda, a escolha dos diretores das unidades escolares pode ser feito pela comunidade escolar, desde que os mesmos, tenham passado pelo curso de gestão oferecido pela secretaria de educação. Ou seja, essa descentralização centralizada aumenta as responsabilidades das unidades escolares no processo de gerenciamento ou, como já exposto anteriormente, busca criar uma nova relação entre a superestrutura do Estado e as unidades escolares. Nessa nova relação cabem as unidades escolares resolver quase todos os problemas e “criar" novas soluções para resolve os novos problemas.

\subsection{O Programa Nova Escola e a Reorientação Curricular.}

É neste contexto, digamos que, no auge do Programa Nova Escola, quando o mesmo encontra-se bem incorporado na rede e bem mais vivenciado pela comunidade escolar, que surge o documento de Reorientação Curricular.

$\mathrm{Na}$ nossa compreensão, este documento possui o objetivo de fortalecer o processo de avaliação das escolas da rede e fechar o ciclo do Programa Nova Escola. Vale lembrar que no processo de avaliação das escolas, todos os alunos fazem uma prova de matemática e língua portuguesa. Parece que se torna transparente aos órgãos públicos que para avaliar de uma forma mais significativa e completa é necessário uma inclusão de novas disciplinas na prova que busca medir o desempenho dos alunos. $\mathrm{E}$ com isto, a avaliação tornar-se-ia mais "justa" aos olhos da comunidade escolar e os indicadores, retratariam as instituições com maior veracidade.

Estas questões apresentadas trazem à reflexão a importância da discussão do tema Avaliação Institucional, no "Programa Nova Escola". No caso, quem está sendo avaliado, na verdade, é o professor e o sistema de ensino. A avaliação funciona como um meio para verificar se o currículo determinado pelo governo está sendo efetivamente ensinado. Ou seja, os professores são o elo entre a política governamental e sua transposição para a realidade prática.

Entendemos que em qualquer reforma educacional as questões curriculares tornam-se um dos pilares fundamentais. Pois como aponta Coll (1996) é no currículo que concretiza-se e toma corpo um série de princípios ideológicos, pedagógicos e psicopedagógicos que, em conjunto, mostram a orientação geral do sistema 
educacional. E isto não é diferente com a "Reorientação Curricular" que procura dar um norte ao sistema educacional da rede, uma "reorientação à avaliação do "Programa Nova Escola”. Pois como afirma César Coll.

Entre outras coisas, a elaboração de um projeto curricular pressupõe a tradução de tais princípios em norma de ação, em prescrições educativas, para elaborar um instrumento útil e eficaz na prática pedagógica. $\mathrm{O}$ currículo é um elo entre a declaração de princípios gerais e sua tradução operacional, entre a teoria educacional e a prática pedagógica, entre o planejamento e a ação, entre o que é prescrito e o que realmente sucede nas salas de aula. É lógico, portanto que a elaboração do currículo ocupe um lugar central nos planos de reforma educacional e que frequientemente ele seja considerado como ponto de referência para guiar outras atuações (por exemplo, formação inicial e permanente do corpo docente, organização dos centros de ensino, confecção de materiais didáticos etc.) e assegurar em última instância, a coerência das mesmas. (Coll, 1996: 33; 34).

Na mesma linha de interpretação Sacristán (1998: 106), afirma "O currículo não pode ser entendido à margem do contexto no qual se configura e tampouco independente das condições que se desenvolve; é um objeto social e histórico e a sua peculiaridade dentro de um sistema educativo é um importante traço substancial". Discutir o documento de Reorientação Curricular de forma relevante é desvendá-lo dentro do seu contexto social, cultural, histórico e político. É a política curricular que estabelece de forma decisiva as coordenadas dentro contexto do Programa Nova Escola. É a política curricular que governa as decisões gerais e se manifesta numa certa ordenação jurídica e administrativa como afirma Sacristán.

O sistema curricular é objeto de regulações, econômicas, política e administrativas. Tendo o currículo implicações tão evidentes na ordenação do sistema educativo, na estrutura de centros e na distribuição do professorado, é lógico que um sistema escolar complexo e ordenado tão diretamente pela administração educativa produza uma regulação do currículo. Isso se explica não só pelo interesse político básico de controlar a educação como sistema ideológico, mas também pela necessidade técnica ou administrativa de ordenar o próprio sistema educativo, o que é uma forma tecnificada de realizar a primeira função. (Sacristán, 1998: 108).

Portanto, além de um papel cultural e social, e isso procuramos deixar claro no primeiro capítulo da pesquisa, o currículo possui uma natureza de exercer o controle 
sobre a escola e os indivíduos conforme afirma Sacristán (1998:108), onde "a regulação dos sistemas curriculares por parte do sistema político administrativo é uma conseqüência da própria estrutura do sistema educativo e da função social que cumpre. Pensar a ordenação do currículo faz parte da intervenção do Estado na organização da vida social".

...ordenar a distribuição do conhecimento através do sistema educativo é um modo não só de influir na cultura, mas também em toda ordenação social e econômica da sociedade. Em qualquer sociedade complexa é inimaginável a ausência de regulações ordenadoras do currículo. Podemos encontrar graus e modalidades diferentes de intervenção, segundo épocas e modelos políticos, que têm diferentes consequiências sobre o funcionamento de todo o sistema.(Sacristán, 1998: 108).

Para o Programa Nova Escola, torna-se necessário um currículo único para as unidades de ensino onde os conteúdos escolares fossem trabalhados de forma comum entre todos na rede. Daí uma das justificativas apresentadas para a existência do documento quando fala sobre a seriação particularmente na área de Geografia.

Uma das principais questões vividas pela escola da rede pública estadual de ensino presente relaciona-se à seriação dos conteúdos programáticos. A ausência de um "padrão de referência" tanto dificulta a transferência de alunos vindos de outras escolas, ou mesmo de outros estados, quanto dificulta a continuidade do trabalho docente. (RJ, 2006: 79).

Com a reorientação curricular, todas as disciplinas devem seguir um "padrão de referência", ou seja, um programa único para todas as escolas de ensino fundamental e médio da rede. E esse programa único também é prescrito para área de Geografia como veremos posteriormente.

Entretanto, entendemos que este currículo é para além das práticas pedagógicas (aliás, como qualquer currículo), pois apesar do aparente inocente título de Reorientação Curricular - o que este documento busca na verdade é uma uniformização do sistema educacional de ensino do estado Rio de Janeiro. Não se padroniza um sistema educacional somente pelas práticas pedagógicas porque subjacentes a elas estão presentes as teorias educacionais. Já as teorias educacionais carregam consigo princípios mais gerais de como se pensa a sociedade e sua visão de mundo. Logo, como abordado no primeiro capítulo deste trabalho nenhum currículo é neutro ou 
desinteressado, em todos os currículos, encontram-se embutidos relações de poder, atitudes políticas.

O Documento de Reorientação Curricular da SEE-RJ, na nossa compreensão traz no seu interior uma dimensão política de princípios neoliberais, busca nas suas entrelinhas viabilizar, no interior do processo educativo, a busca pela qualidade, a lógica do mercado para dentro do sistema educacional das escolas públicas do estado do Rio de Janeiro.

No próximo capítulo, identificaremos através da análise dos discursos produzidos pelo documento de Reorientação Curricular a lógica neoliberal construído nas suas entrelinhas e buscar compreender o papel da ciência geográfica neste contexto. 


\section{O documento de "Reorientação Curricular" da rede estadual de ensino do Rio de Janeiro.}

Iniciamos este capítulo procurando caracterizar a rede de escolas estaduais públicas do Rio de Janeiro para traçar um panorama do universo maior no qual se encontra inserido o projeto de Reorientação Curricular. Tão importante quanto a avaliação teórico-metodológica do documento de reorientação curricular é compreender o cenário de sua implementação, pois, o cenário de alguma forma e por maneiras distintas revela as políticas subjacentes à educação. Neste sentido são apresentados alguns dados sobre os estabelecimentos de ensino, número de matrículas, coordenadorias regionais e situação das escolas da rede. Além de contextualizar a reorientação curricular com o Programa Nova Escola.

Posteriormente, apresentamos os princípios e objetivos mais gerais da Reorientação Curricular na escola, bem como a ciência geográfica se apresenta no documento, suas idéias e concepções - para tanto, apresentamos passagens do documento que se referem aos seus objetivos.

Por último, é feito um contraponto da estrutura do documento de Reorientação Curricular com os Parâmetros Curriculares Nacionais para o ensino médio e finalizamos com uma análise crítica de sua fundamentação teórica e metodológica para o ensino de Geografia.

\subsection{Um panorama da rede estadual de ensino do Rio de Janeiro}

A rede pública de ensino do Estado do Rio de Janeiro é composta, segundo os dados da Secretaria Estadual de Educação ${ }^{23}$, referentes ao ano de 2006, por 1646 escolas $^{24}$, um número bem menor que o registrado no ano 2000 quando ocorre a implementação do Programa Nova Escola ${ }^{25}$, quando a rede possuía 1925 unidades $^{26}$.

Essas unidades escolares encontram-se supervisionadas e distribuídas por 29 coordenadorias regionais. De acordo com o censo de 2006, o número total de matrículas

\footnotetext{
${ }^{23}$ Fonte, página da SEEDUC- RJ - http://www.educacao.rj.gov.br/

${ }^{24}$ Fonte: Censo Escolar 2006/INEP/Mec

${ }^{25}$ Programa de avaliação da rede de ensino elaborada durante o governo de Anthony Garotinho (19992002).

${ }^{26}$ Segundo dados levantados por Jorge Najjar, publicados em sua tese de doutorado concluída em 2004 , na Faculdade de Educação - USP.

Essa redução deve-se ao processo de municipalização das escolas que possuíam apenas o ensino fundamental.
} 
da rede foi de 1.441 .727 alunos, sendo que 506.254 no ensino fundamental, 573.883 no ensino médio e 172.961 no EJA presencial e o restante diluído entre as outras várias modalidades de ensino. É importante mostrar esses números para termos a idéia do tamanho da rede estadual de ensino, porque a dimensão desses dados quantitativos traz à tona uma outra reflexão - a diversidade da rede. A rede estadual concentra $34,1 \%$ do total de matrículas do estado, enquanto as redes públicas de todos os municípios juntos concentram 43,7 \% do total de matrículas do estado. São 1.441 .727 alunos da rede pública estadual contra ou 1.844.826 de alunos da redes públicas municipais.

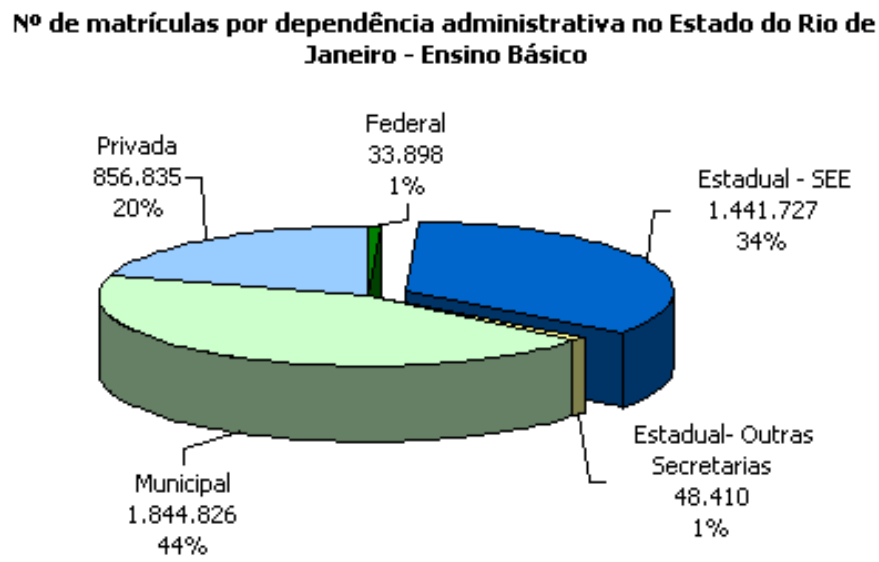

(fonte: www.educacao.rj.gov.br)

Quadro 4

Número de alunos por modalidade de ensino da SEE - Censo Escolar 2006

\begin{tabular}{|c|c|c|c|c|c|c|c|c|c|c|c|}
\hline $\begin{array}{c}\text { Educaçã } \\
o \\
\text { Infantil - } \\
\text { Creche }\end{array}$ & $\begin{array}{c}\text { Educaçã } \\
\text { o } \\
\text { Infantil } \\
\text { - Pré- } \\
\text { Escola }\end{array}$ & $\begin{array}{c}\text { Ensino } \\
\text { Fundament } \\
\text { al - Iniciais }\end{array}$ & $\begin{array}{c}\text { Ensino } \\
\text { Fundament } \\
\text { al - Finais }\end{array}$ & $\begin{array}{l}\text { Ensino } \\
\text { Médio }\end{array}$ & $\begin{array}{c}\text { EJA } \\
\text { Presenci } \\
\text { al - EF }\end{array}$ & $\begin{array}{c}\text { EJA } \\
\text { Presenci } \\
\text { al - EM }\end{array}$ & $\begin{array}{c}\text { EJA } \\
\text { Semi- } \\
\text { Presenci } \\
\text { al - EF }\end{array}$ & $\begin{array}{l}\text { EJA } \\
\text { Semi- } \\
\text { Presenci } \\
\text { al - EM }\end{array}$ & $\begin{array}{c}\text { Educaçã } \\
\quad 0 \\
\text { Especial }\end{array}$ & $\begin{array}{l}\text { Educ } \\
\text { Prof }\end{array}$ & Total \\
\hline 136 & 12.278 & 152.451 & 353.803 & $\begin{array}{r}573.83 \\
3\end{array}$ & 128.772 & 44.189 & 69.846 & 87.149 & 3.784 & $\begin{array}{r}15.48 \\
6\end{array}$ & $\begin{array}{r}1.441 .72 \\
7\end{array}$ \\
\hline
\end{tabular}

(fonte: www.educacao.rj.gov.br)

Como já colocado, o número de escolas da SEE-RJ vem diminuindo ao longo dos anos e há atualmente em curso, dentro das esferas do governo, um processo de municipalização de parte da rede, entregando aos municípios as escolas de ensino fundamental e educação infantil. O atual governador do estado, Sérgio Cabral, para justificar a falta de professores nas $\operatorname{escolas}^{27}$ argumenta que a municipalização é

\footnotetext{
${ }^{27}$ Segundo o SEPE - Sindicato Estadual dos Profissionais da Educação - a carência de profissionais no início do ano letivo de 2008 beirava algo em torno de 26 mil profissionais.
} 
necessária, pois, segundo LDBEN a obrigação do Estado é de cuidar apenas do ensino médio, cabendo aos municípios a responsabilidade sobre o ensino fundamental. Entretanto, entendemos que muitos municípios não se encontram capacitados para absorver parte das escolas da rede estadual. São municípios com sérios problemas de arrecadação, que sobrevivem com repasses orçamentários do governo federal. Na nossa compreensão, a redução da rede estadual de ensino possui um único objetivo, reduzir os gastos do governo estadual com a educação.

Outra importante característica da Rede Estadual de Ensino do Rio de Janeiro é o seu processo de sucateamento - a sua completa falta de infra-estrutura, a carência de escolas, de pessoal de apoio e professores. As redes municipais ao longo dos anos, durante as últimas duas décadas, principalmente na região metropolitana, passaram por um processo de ampliação. Com a criação do Fundef as prefeituras tiveram um volume maior de recursos para cumprir com o processo de universalização da educação fundamental, provocando assim, um aumento no número total de alunos que chegaram ao ensino médio. Foi comum durante o governo de Anthony Garotinho (1999-2002) e de Rosinha Garotinho (2003-2006), a ausência de planejamento para receber a grande demanda de alunos proveniente das redes municipais.

Nesses governos, a prática mais utilizada para resolver os problemas de carência de infra-estrutura foi a de alugar antigos prédios de escolas privadas fechadas ou de antigos imóveis desativados que servissem para funcionar como escolas, ou ainda, utilizar as escolas das redes municipais no período noturno. Como exemplo, cito os colégios estaduais Maria de Nazareth e Compositor Manacéia de Andrade ambas localizadas respectivamente nos bairros de Cascadura e Madureira e que fazem parte da Coordenadoria Regional Metropolitana III, subúrbio carioca. Criados na gestão do Governador Anthony Garotinho essas escolas funcionavam em prédios de antigas escolas particulares desativadas. Durante alguns anos, essas unidades permaneceram em péssimas condições. Em algumas salas, não havia sequer quadro negro e os professores escreviam com o giz nas divisórias que formavam as mesmas. Nesses dois governos nenhuma escola foi construída agravando e piorando ainda mais uma rede que já vinha sendo sucateada ao longo dos anos.

Para resolver a carência de professores o Governo Anthony Garotinho criou, no ano de 2000, a GLP (regime de Gratificação por Lotação Prioritária), mecanismo que permite aos professores ampliarem sua carga horária de trabalho em até 24 horas semanais. Foi muito comum, professores com duas matrículas ampliarem a carga 
horária e chegar a uma jornada de 48 horas/aulas semanais somente na rede estadual, sem contar com a carga horária extra-classe $\mathrm{e}^{28}$.

Quanto ao quadro de funcionários, há muito, o governo do estado do Rio de Janeiro não realiza concurso para o pessoal de apoio prejudicando todo o funcionamento das escolas. A solução "encontrada", e cada vez mais presente, a terceirização dos públicos, inviabiliza um melhor funcionamento pedagógico das escolas. A precarização das relações trabalhistas, principalmente no setor público, segue quase sempre uma mesma lógica - a redução dos custos com a mão-de-obra. No processo de terceirização da mão-de-obra escolar, é comum funcionários de serviços de limpeza que possui melhor escolaridade ser desviado para funções administrativas e de secretaria.

Entendemos que, do ponto de vista da infra-estrutura física, a Rede Estadual de Ensino do Rio de Janeiro apresenta uma carência extrema de profissionais, tanto em quantidade como em qualidade, e de condições de trabalho e que isto contribui para a redução da qualidade da educação. A síntese desse sucateamento, em parte, se traduz nos péssimos índices de aproveitamento nas avaliações feitas pelo governo federal. No Exame Nacional de Ensino Médio de 2007, das 100 escolas que obtiveram os menores índices de aproveitamento no município do Rio de Janeiro, nada menos que 99 pertenciam à rede pública estadual. A escola com melhor índice de aproveitamento nesta avaliação encontrava-se na posição de $107^{\circ}$ lugar, o Colégio Estadual Professor Horácio Macedo. Escola esta que possui uma parceria com o Centro Federal de Tecnologia - CEFET-RJ.

Entendemos que para solucionar parte desses problemas, o governo do estado vai utilizar de uma fórmula, um receituário que nasce, em nossa avaliação, dos técnicos do Banco Mundial e de agências internacionais e que entra na agenda fluminense a partir do ano 2000. Não há coincidência nenhuma no fato de não existir construções de escolas na década de 1990 e a última grande ampliação da rede ter existido nos anos de 1980, pois, hoje, o foco do Banco Mundial não é o de financiar a construção de escolas, mas de criar políticas para o gerenciamento das escolas. É fato que existe uma lógica a ser seguida e entendemos que é neste quadro que nasce o "Programa Nova Escola". Programa este que, segundo o discurso oficial, busca resolver todos os problemas das escolas da rede do estado do Rio de Janeiro. Compreendemos também que é dentro

\footnotetext{
${ }^{28} \mathrm{O}$ Regime de trabalho do professor de $5^{\mathrm{a}}$ a $8^{\mathrm{a}}$ série e ensino médio da SEEDUC-RJ é de 16 horas de trabalho sendo 12 horas em sala e 4 horas como complementação ou extra-classe.
} 
deste contexto que surge a Reorientação Curricular da rede de ensino que é irmã siamesa do "Programa Nova Escola"

\subsection{Apresentando a Reorientação Curricular}

A Secretaria de Educação do Estado do Rio de Janeiro apresentou no início do ano letivo de $2005^{29}$ um documento intitulado "Reorientação Curricular" proposto para a educação básica (ensino Fundamental e Médio) e apresentado em três volumes, um para cada uma das grandes áreas ${ }^{30}$ de organização do conhecimento escolar: Linguagens e Códigos (Livro I), Ciências da Natureza e Matemática (Livro II) e Ciência Humanas (livro III). Nessas áreas do conhecimento escolar estão organizadas as tradicionais disciplinas escolares. No Livro I se encontram concentradas as disciplinas de Língua Portuguesa, Língua Estrangeira, Educação Física e Educação Artística. No Livro II estão presentes as disciplinas de Matemática, Química, Biologia, Física e Ciências para o ensino fundamental. Por último, no Livro III, as disciplinas presentes são: Geografia, História, Filosofia e Sociologia.

O documento foi elaborado por uma equipe contratada de consultores de instituições de ensino superior e professores da própria rede, coordenados por uma equipe de profissionais da Universidade Federal do Rio de Janeiro (UFRJ), com o objetivo de criar orientações para nortear o exercício docente e assim ser capaz de contribuir para melhoria dos padrões de qualidade de ensino.

A primeira versão do documento foi apresentada aos professores sob a forma de proposta, num Workshop realizado em novembro de 2004. Posteriormente, segundo a própria Secretaria, o documento foi enviado a todas as escolas, acompanhada de um

\footnotetext{
${ }^{29}$ Foram publicadas pela Secretaria de Educação outras orientações curriculares para o ensino normal, em um único volume (Livro IV - Curso Normal) e para Educação de Jovens e Adultos nos seguintes volumes:

Livro V - EJA - Linguagens e Códigos - EF

Livro VI - EJA - Ciências e Matemática - EF

Livro VII - EJA - Ciências Humanas - EF

Livro VIII - EJA - Linguagens e Códigos - EM

Livro IX - EJA - Ciências da Natureza e Matemática - EM

Livro X - EJA - Ciências Humanas - EM

${ }^{30}$ Áreas do conhecimento que foram definidas conforme as Diretrizes Nacionais Para o Ensino Médio (DCNEM).
} 
formulário específico para avaliação com o objetivo de obter sugestões e críticas. Em 2006 ganhou seu corpo definitivo, e hoje está presente, pelo menos na forma impressa, em todas as escolas da rede.

\subsection{Apresentando dos princípios e objetivos da Reorientação Curricular}

O documento de Reorientação Curricular a Secretaria Estadual de Educação do Rio de Janeiro expõe as necessidades que levaram a construção de um novo currículo para as escolas da rede:

a) o grave quadro apresentado pelas avaliações institucionais, como o SAEB e o ENEM do Governo federal e o "Programa Nova Escola" do governo estadual;

b) um número expressivo de alunos que não desenvolvem as habilidades básicas para o nível escolar que estão freqüentando;

c) a falta de aprendizagem de conteúdos e competências básicas para a vida;

d) a distorção idade-série, tempo de conclusão, elevados índices de evasão e repetência e o aprofundamento das desigualdades sociais e étnicas.

A Secretaria também alega que o último documento curricular foi elaborado em $1994^{31}$ e que posteriormente a ele houve, no Brasil, significativas transformações no campo da educação como o advento da LDBEN 9394/96.

Diante deste quadro a Secretaria de Educação afirma que é imprescindível a existência, na rede pública estadual, de uma orientação curricular que estimule a discussão sobre as questões da educação básica e apresente as saídas para alguns dos problemas, entendendo que para ajudar a resolvê-los, uma orientação curricular deve obedecer aos princípios que articulem a escola ao projeto político pedagógico e currículo. Assim:

Estabelecer uma reorientação curricular significa definir parâmetros e linhas, a partir de idéias e pressupostos, discutidos e compartilhados pelas escolas, que contribuam para uma efetiva, construção do Projeto Político Pedagógico da escola e na construção do currículo de cada escola, que devem incorporar suas condições e singularidades sem perder de vista o direito de todos a uma educação de qualidade. (RJ, 2005: 15)

\footnotetext{
${ }^{31}$ Este documento intitulava-se Proposta de Plano Básico de Estudos do qual tivemos acesso apenas o volume construído para o segundo segmento do ensino fundamental.
} 
A idéia central passa pela concepção de que o currículo tende a ser um elemento homogeneizador na educação e que busca corrigir e melhorar o padrão e a qualidade da educação nas escolas da rede, através da correção e redução das desigualdades dentro de uma mesma escola e entre as diversas escolas. É o currículo que vai conectar e corrigir essas desigualdades, como afirma o documento.

Como pensar na melhoria da qualidade em educação e na redução das desigualdades dentro das escolas e entre as escolas se o trabalho é desenvolvido de forma desconectada, sem um projeto que promova um direcionamento comum para o ensino básico público estadual? (RJ, 2006: 15).

É nesse sentido da idéia de currículo homogeneizador, pela busca das mesmas metas e padrões, e de uma suposta qualidade, que o currículo proposto pela SEE - RJ vai fundamentar seus princípios. Mas quais são esses princípios?

O documento Reorientação Curricular apresenta como princípio norteador, de sua concepção "ser para as escolas da rede precisamente uma orientação curricular, ou seja, nortear o processo de elaboração e construção do planejamento político pedagógico e do currículo das escolas da rede estadual pública o Estado do Rio de Janeiro" (RJ, 2006:15). Nesse sentido, toda escola da rede deve elaborar seu projeto político pedagógico, seu próprio currículo e programas curriculares, respeitando as orientações propostas pela secretaria de educação.

Ao currículo precisam ainda ser associados os programas curriculares, organizados por área de conhecimento, por disciplinas, por série. Estes programas devem possuir uma ordem lógica, que respeite a epistemologia da área de conhecimento, e apresentar claramente as opções metodológicas conceituais.

E é a partir deste conjunto - Projeto Político Pedagógico, Currículo e programas curriculares - que o professor pode com segurança, construir o plano de curso para a sua turma naquele ano. O que esse documento se propõe, novamente é ser uma orientação curricular, fornecer as bases para a construção coletiva deste conjunto na escola. (RJ, 2006:16).

No entanto a Reorientação Curricular não explicita e não dá nenhuma definição do que seja um projeto político pedagógico e nem como se constrói. Porém, sinaliza 
para a comunidade escolar diferenças entre currículo e programa curricular quando coloca que:

Do ponto de vista de sua organização, os componentes do programa curricular devem ser: os objetivos para aprendizagem, as estratégias de ensino, uma visão comum sobre os processos de aprendizagem e a interação entre estes e os materiais didáticos selecionados como suporte do trabalho cotidiano. Um programa curricular precisa ser coeso e coerente. (RJ, 2006:16).

E sobre o que seja um programa curricular coeso e coerente, explica da seguinte forma:

Por coerente entendemos programas curriculares nos quais a conexão entre as idéias está clara, o desenvolvimento dos conceitos e dos métodos apresentados ao aluno passo a passo (e ano a ano) tem sentido lógico. É necessário que os estudantes construam novas idéias a partir das idéias anteriormente apresentadas e desenvolvidas durante o processo de ensino.

Por coeso, entende-se um programa que permita uma visão global do processo tanto para os professores quanto para os gestores. O que isto significa exatamente? Significa compreender que muitas competências e saberes não são exclusivos de apenas uma disciplina, mas só são construídos e consolidados pelo conjunto da diversidade de experiências e enfoques. Esta visão mais abrangente, exigência da sociedade atual, nos obriga - formuladores e implementadores de programas - a ter uma visão coletiva das metas e objetivos de aprendizagem dos estudantes (RJ, 2006:16 - 17).

No entanto, os autores do documento enfatizam que no processo de formulação do mesmo, levaram-se em conta algumas questões que devem ser respondidas por um currículo: a quem ensinar e para que ensinar? O que e quando ensinar e como ensinar?

São com essas questões que a Reorientação Curricular busca construir objetivos para a sua existência respondendo-as das seguintes maneiras: "Devemos ensinar com o objetivo de atingir a todos os estudantes da rede estadual do Rio de Janeiro, independentemente do nível sócio econômico, do nível cultural de sua família e de sua comunidade, da raça e do gênero". (RJ, 2006: 19).

Ao tratar sobre a questão "para quem ensinar" o documento afirma com clareza e objetividade que é para formar indivíduos com uma atitude responsável e solidária 
perante o Mundo e que os conhecimentos adquiridos na escola devem servir para aplicálos em suas "realidades".

Quando se refere aos questionamentos "o que e quando ensinar", o documento propõe que "para o processo de elaboração dos programas curriculares, as equipes sugerem conceitos e conteúdos considerados fundamentais em cada uma das áreas de ordenação destes de forma seriada" (RJ, 2006: 19). E que estes conceitos e conteúdos levam em conta o processo de aprendizagem e a preocupação com as interfaces de disciplinas diferentes e áreas diversas para que os programas curriculares não se apresentem de forma fragmentada.

No que tange a proposta de "como ensinar" o documento sinaliza que são sugeridos "orientações metodológicas e atividades originadas da troca de experiências entre os professores da rede pública estadual e da universidade" (RJ, 2006: 19). Nesse momento cabe uma explicação sobre as orientações metodológicas e atividades. No ano de 2005 a SEE-RJ em conjunto com professores do Departamento de Geografia da UFRJ e do Colégio de Aplicação da mesma universidade ${ }^{32}$, organizou um ciclo de reuniões nas quais os professores trocaram experiências didáticas e pedagógicas. $\mathrm{O}$ resultado deste processo foi a publicação de um caderno com sugestões de atividades práticas, com diversos temas da Geografia (urbano, agrário, regional mundo, globalização, etc.) para serem desenvolvidos em aula. Esse caderno de atividades foi publicado em conjunto com a versão da Reorientação Curricular 2006 e é esse caderno que norteia a proposta de "como ensinar".

$\mathrm{Na}$ questão interdisciplinar, o documento faz as seguintes observações: um programa curricular é composto basicamente de disciplinas e o conhecimento específico é profundamente inter-relacionado com outros conhecimentos disciplinares. Ressalta que a interdisciplinaridade não é tarefa fácil e é construída passo a passo por intermédio da interação entre as disciplinas. Afirma que essa interação entre as disciplinas exige dos professores atitudes, comportamentos e trabalho em equipe.

Ao final da apresentação do documento de Reorientação Curricular, a SEE - RJ expõe o papel do professor no processo e afirma que o mesmo é peça-chave para mudar o grave quadro educacional em que se encontra a rede estadual de ensino. Porém, reconhece a precarização da profissão e caracteriza os professores da seguinte forma.

\footnotetext{
${ }^{32}$ O nome dos autores que elaboraram a Reorientação Curricular para o ensino de Geografia são listados na parte de anexos desta pesquisa.
} 
E quem somos nós? Em geral, no Brasil, o professor recebe uma formação profissional inicial precária, enfrenta difíceis condições de trabalho, convive com baixos salários, tem dificuldades de acessos a livros ou, mais geralmente, à produção cultural, científica, tecnológica de seu país e de seu tempo. Este profissional trabalha de forma muito solitária, e tem dificuldades de encontrar mecanismos de aperfeiçoamento profissional que lhe permitam manter-se atualizado em relação à sua profissão. (RJ, 2006: 21)

Apesar de reconhecer todos os problemas que caracterizam a formação do professor e as condições de trabalho precarizadas, o documento faz elogios ao esforço pessoal dos profissionais quando os mesmos realizam boas experiências na busca por melhores aulas que promovam verdadeiras aprendizagens nos alunos.

E no final desta abordagem introdutória sobre os princípios gerais do documento, o mesmo afirma que é impossível implementar um currículo coeso e coerente, que funcione de fato, sem uma verdadeira participação ativa do professor e coloca que reformas curriculares bem elaboradas nunca foram implementadas sem a participação coletiva dos profissionais da educação.

No entanto, sem a nossa participação coletiva, reformas curriculares não saem do papel e programas muito bem elaborados fracassam quando implementados (RJ, 22 : 2006)

Em suma, nestas páginas introdutórias do volume III da Reorientação Curricular queremos frisar que nossas concordâncias são maiores que as discordâncias daquilo que foi elaborado. Entendemos que é papel do Estado criar políticas públicas para educação, viabilizando a construção de guias ou orientações curriculares para nortear o processo de autonomia das escolas, contribuindo na elaboração do projeto político pedagógico e dos planos de aulas das mesmas. Concordamos também com determinadas premissas do Documento no que tange "a quem ensinar e para que ensinar" e também "O que e quando ensinar e como ensinar". Não há discordância significativa nesses princípios de que a escola deva ensinar para "formar indivíduos com uma atitude responsável e solidária perante o Mundo". Também não discordamos que os professores devam elaborar programas com conceitos e conteúdos considerados fundamentais em cada uma das disciplinas e que esse processo se dê com coerência e coesão, não só por séries, mas por princípios lógicos da pedagogia e das disciplinas que compõe o currículo escolar. No entanto, o que questionamos nesta pesquisa são: esses 
princípios aparecem com essa coerência ao longo do documento? Esses fundamentos de fato vão orientar a reorientação para a Geografia? É isto que veremos mais adiante neste capítulo.

\subsection{Apresentando os princípios e objetivos da Reorientação Curricular para a} Geografia

No que tange a reorientação curricular para o ensino de geografia o documento proposto, na sua apresentação, afirma à importância do ensino desta ciência em face da complexidade das contradições do mundo atual e que a mesma, junto com a História, cumpriram um importante papel político-pedagógico nos processos de construção simbólica da nação difundindo os conhecimentos sobre o território, a natureza e a população.

No documento, o ensino de Geografia ganha cada vez mais importância, na atualidade, devido ao processo de globalização em curso, que traz a tona os temas já sedimentados e construídos por esta ciência na sua trajetória escolar. Consta que importância de ensinar esta disciplina atualmente deve-se:

a multiplicidade de temas e conteúdos abarcados tradicionalmente pela Geografia e, ainda, a divisão atual do trabalho escolar tornam o seu ensino um espaço privilegiado de interlocução com os alunos. Afinal, no mundo atual, nos dias da globalização, ou melhor, no meio a fluidez do nosso tempo, da profusão de redes de comunicação, das conexões outrora improváveis, o território para uns, o lugar para outros, a região e a paisagem voltam à cena como expressão dos conflitos e disputas contemporâneos. Palavras que remetem a conceitos caros à Geografia invadem noticiários, ocupam as páginas dos jornais, pontuam o dia a dia e são tematizados em sala de aula, promovendo a atualização de assuntos tradicionalmente tratados pela disciplina. $O$ conceito de espaço geográfico e as questões relativas às dinâmicas ambientais e à geopolítica - incluindo o conhecimento dos recursos naturais, o seu significado geoestratégio e o seu valor de mercado internacional - são instrumentos e temas que favorecem o debate sobre questões que mobilizam os alunos e invadem a sala de aula. (RJ, 2006: 73)

$\mathrm{Na}$ seqüência, o documento, procura relacionar temas que ocorrem na contemporaneidade a assuntos que devem ser tratados pelo ensino desta ciência na escola. 
Assim, conceitos e temas caros à geografia contituem-se em ferramentas importantes para o entendimento da complexa sociedade contemporânea, para a interpretação dos fenômenos socioambientais e socioeconômicos. A eles está associada a proliferação de novos confrontos cotidianos referidos às tradições religiosas, ao pertencimento territorial, à valorização do ambiente e às muitas vozes que reivindicam direitos sobre o espaço: territórios, paisagens, lugares, biomas ameaçados. É o que noticiam conflitos em torno de "áreas de conservação", "terra de quilombo", "terras indígenas" ou aquelas dominadas pelo narcotráfico. São conflitos territoriais e processos sociais que configuram e reordenam, no contexto brasileiro, uma complexa malha de gestão do território. Trazem, por sua vez, para a cena política nacional e internacional a biodiversidade planetária, as reservas minerais, a água, as florestas, as mudanças climáticas globais, a, a apropriação desigual dos recursos e, com isso a multiplicidade dos agentes sociais que disputam tanto espaços quanto recursos dos quais muitas vezes dependem, colocando de forma eloqüente a natureza "dentro da sociedade" que nela se apropria. (RJ, 2006: 73)

Nota-se o que o documento de Reorientação Curricular expõe sobre a importância do ensino de Geografia, a sua temática atual, as contradições do mundo e a fluidez do espaço. Aborda a importância em apreender as contradições do mundo através da análise do espaço vivido e explicita as categorias de análise e compreensão do espaço (lugar, território, rede, paisagem) como um importante instrumental teórico para leitura da realidade.

Entretanto, será que esta concepção teórico-metodológica encontra-se presente no cerne da concepção de currículo e Geografia adotada? Fica a questão levantada para ser respondida mais a frente. No entanto, pensamos que a Geografia não ganha mais importância na escola devido ao processo de globalização, mas sim que a globalização e os novos temas resultantes desse processo serão incorporados em nossas aulas, como em outras disciplinas do currículo escolar. Dessa forma, a Geografia em face ao processo de globalização, tem seu potencial intensificado devido à complexidade de fenômenos do mundo atual, mas não que esses fenômenos ampliem a sua importância.

\section{A concepção de Geografia adotada pela Reorientação Curricular}

O documento de Reorientação Curricular traz uma proposta de ensino de Geografia, fundamentada sobre os seguintes aspectos: a importância de se estudar esta disciplina nas escolas; os saberes relevantes desta ciência no cotidiano dos alunos; as 
competências e habilidades desenvolvidas durante a sua aprendizagem e como esta disciplina ajuda a construir uma proposta interdisciplinar. Com base nesses fundamentos, os autores constroem um programa curricular levando em consideração mais dois critérios: Os programas curriculares desenvolvidos pelo MEC no final dos anos de 1990, com destaque para os PCNs do ensino fundamental e médio, e os livros didáticos mais vendidos no mercado editorial.

Para os autores da Reorientação Curricular, estudar Geografia é situar os homens no espaço social, um espaço social que é marcado pela velocidade com que circulam as informações, pelo jogo político entre as nações e pela dinâmica que modifica o traçado das fronteiras políticas internacionais. Estudar Geografia é entender o crescimento das cidades e a qualidade de vida urbana, as transformações da vida no campo e as questões ambientais. Esses são alguns exemplos dados que colocam a importância do estudo desta ciência na escola. Contudo, o objetivo central do ensino desta ciência concebida no documento está na compreensão do espaço geográfico, como categoria central, que constrói o entendimento de mundo.

As grandes tarefas e os desafios do ensino de Geografia são levar o aluno a compreender o espaço geográfico e a sua transformação ao longo do tempo, auxiliando a sua integração na sociedade e convidando-o (sic!) a participar ativamente da construção e reconstrução do espaço, seja em escala local ou escala global. Contribuir para a formação do cidadão ativo e crítico e para o desenvolvimento de formas e estratégias de pensamento desse mesmo sujeito crítico. Espera-se que ao aprender a ler, a escrever e a pensar estudando Geografia os educandos se apropriem do conhecimento científico para formular suas próprias hipóteses e aplicar aos métodos de investigação, encontrando respostas às questões que os inquietam. (RJ, 2006:75-76)

E para que as tarefas citadas sejam bem sucedidas, o professor deve desenvolver os conceitos e temas sedimentados na ciência geografia (espaço geográfico, paisagem, lugar, território, escala, globalização, técnicas e redes), e que esses temas estejam comprometidos com a "realidade" do espaço geográfico e com o público a quem vai ser oferecido o estudo. Nesse contexto, os conteúdos trabalhados devem servir de instrumentos para atingir os objetivos propostos que não são os conhecimentos específicos da Geografia, mas no desenvolvimento das habilidades e competências que foram listadas de acordo com os Parâmetros Curriculares Nacionais da seguinte forma: 
Competência e Habilidades Pretendidas com o Ensino de Geografia.

As competências foram sintetizadas em vista as práticas mais imediatas dos professores. Promovem um recorte em relação ao vasto conjunto de competências e habilidades propostas pela Lei de Diretrizes e Bases (LDBEN 9394/96) e às indicações sugeridas pelos Parâmetros Curriculares Nacionais (PCNs).

Assim, ao longo de sua escolarização, espera-se possibilitar ao aluno.

- $\quad$ Adquirir o pleno domínio da linguagem cartográfica (croquis, mapas, gráficos, imagens de satélites, etc.) como forma de representar o espaço os fatos e os fenômenos no espaço geográfico.

- Dominar as noções de escala (cartográfica e geográfica) no conhecimento geográfico.

- Comparar os fenômenos geográficos e reconhecer as diferenças e as semelhanças existentes entre eles.

- Identificar singularidades e generalidades de uma paisagem, lugar ou território no espaço. (RJ, 2006:76)

São essas as habilidades e competências que o documento de reorientação curricular, no que se refere à geografia, propõe para que os professores desenvolvam em sala de aula para contribuir com a formação de cidadãos críticos.

Sobre a formação de cidadãos críticos o documento afirma que dois aspectos devem ser observados: a visão interdisciplinar dos fatos e fenômenos do espaço geográfico e como aplicar e conhecer em sua vida os conceitos da Geografia. Com relação ao último aspecto o documento expõe as seguintes idéias.

A Geografia ensinada promove a compreensão dos alunos a partir dos espaços concretos, físicos, que fazem parte da sua vivência e deles vão se afastando e se reaproximando da noção de espaço geográfico (sic!). Neste, revelam-se tanto as práticas dos grupos sociais quanto se manifestam os diferentes aspectos da mudança social, das transformações e das incorporações técnicas e se configuram unidades espaciais distintas, como paisagens, lugares, territórios, elementos e conceitos espacias. (RJ, 2006: 77).

Para que os conceitos da Geografia sejam desenvolvidos de forma que contribua para compreender o mundo real e vivido pelos alunos, o documento propõe o trabalho de campo como procedimento de investigação para a produção do conhecimento. Ressalta que a "ida ao campo" favorece o desenvolvimento de habilidades e competências essências, como o exercício da localização, a comparação entre os 
lugares, a elaboração de pequenos relatórios, o tratamento das informações e o estabelecimento das relações, de modo a transformar informações coletadas pela observação direta em conhecimento.

No tocante a interdisciplinaridade o documento aborda a importância da emergência de novos temas tratados pela Geografia, e que isto provoca um maior diálogo com outras ciências. Afirma que a dicotomia entre Geografia física e Geografia humana é muito criticada por vários geógrafos e que esta dicotomia é cada vez mais crescente. No entanto, exalta a dicotomia quando diz que esta amplia a interface e a interdisciplinaridade com outras ciências e relaciona as disciplinas que possui interface com a Geografia.

Além interface com a História, a Sociologia, a Economia, a Política, a Antropologia, apenas para citar algumas também no campo das Ciências Humanas, a interface com o campo das Ciências Naturais não é de menor relevância, seja com a Biologia, a Botânica, a Hidrologia, a Climatologia, seja com a Geologia e outras com outras Ciências Ambientais. Este aspecto, que se acentuou nas últimas décadas, tem reforçado o interesse e a demanda nas aulas de Geografia em relação as questões ambientais, tornado-se este um dos temas transversais do seu ensino. (RJ, 2006: 78).

Ainda sobre a interdisciplinaridade, coloca que a mesma acentuou-se nas últimas décadas, e isto tem reforçado o interesse e a demanda pelas aulas de Geografia em relação às questões ambientais, tornando-se este um dos temas transversais do seu ensino. Afirma que a particularidade de ser uma disciplina que engloba vários aspectos sociais, históricos, biológicos, econômicos, antropológicos, matemáticos, isto é, de diversas áreas do conhecimento, permite à "Geografia ser a norteadora de um processo de maior conscientização do Mundo que nos cerca”. (RJ, 2006; 78)

\section{A proposta de seriação.}

Nessa parte, o documento de reorientação curricular para o ensino de geografia apresenta a proposta de seriação, ou o programa curricular, para os professores desenvolverem em sala de aula. É neste momento que são colocados e determinados os elementos da construção do currículo que segue a seguinte lógica: a sequiência em que devem ser inserido os conteúdos e em que série, e como pensar os temas da disciplina. 
Trata-se de um momento que a organização dos conteúdos se desenvolve em uma ordem predeterminada por princípios lógicos da ciência geográfica. No entanto, cabe uma reflexão sobre esses princípios já que o documento na esclarece seus fundamentos.

É nesse item que os seus autores, argumentam sobre a validade e a necessidade da existência de uma listagem de conteúdos a serem ensinados pelas escolas da rede pública estadual quando expõe da seguinte forma:

Uma das principais questões vividas pela escola da rede pública estadual de ensino no presente relaciona-se à seriação dos conteúdos programáticos. A ausência de um "padrão" de referência tanto dificulta a transferência de alunos vindos de outras escolas, ou mesmo de outros estados, quanto dificulta a continuidade do trabalho docente. (RJ, 2006: 79)

Para que todas as escolas possuam um "padrão de referência", expõe que o processo de seleção dos temas foram organizados e conduzidos tendo em vista que essa disciplina escolar ocupa um longo período dentro da grade curricular (sete anos) e preenche um número significativo de horas no conjunto da educação básica.

Quanto aos critérios desenvolvidos na proposta de seriação, o documento afirma que foram considerados mais relevantes os seguintes argumentos:

- A assimilação dos conteúdos pelos estudantes, a complexidade dos conceitos e temas envolvidos, as habilidades correlatas.

- $\quad$ Tratamento dos temas pelos livros didáticos, em especial aqueles que se adaptaram aos PCNs, nos quais além dos textos, estão disponíveis gráficos mapas e tabelas.

A diversidade social dos alunos que cursam o ensino fundamental e médio com seus múltiplos interesses.

As dimensões multiescalares dos processos espaciais, o cotidiano (local) relacionado aos processos desencadeados a partir de decisões extralocais (nacionais e globais) (RJ, 2006: 78).

Ainda sobre a proposta de seriação, a reorientação para Geografia argumenta que "as sugestões de atividades propostas pretenderam articular conteúdos tradicionais da Geografia a diferentes procedimentos de observação e registro dos fenômenos espaciais.” (RJ, 2006: 79). E quando explica os diferentes procedimentos e registros dos fenômenos espaciais afirma. 
Estas "Grafias" do mundo, produzidas fora dos quadros disciplinares, abraçam temáticas e noções fundamentais para a reflexão sobre o mundo contemporâneo, produzidas fora dos quadros disciplinares, abraçam temática e noções fundamentais para a reflexão sobre o mundo contemporâneo naquilo que compete a Geografia, ou seja, são formas de "cantar", registrar, e "descrever" a paisagem e expressam os significados que o espaço tem para certos grupos sociais. Muitas vezes expressam os significados que o espaço tem para certos grupos sociais, expressam identidades respaldadas num procedimento de determinado território. Falam de desigualdades sociais, da distribuição diferencial dos recursos naturais, da distribuição desigual dos equipamentos urbanos, da hegemonia do mercado. Tais grafias referem-se, aos fluxos imateriais, aos patrimônios locais e nacionais e constituem-se elas mesmas em patrimônio dos que as produzem. É o caso de músicas que apresentam cartografia a partir de perspectivas não-hegemônicas, menos espetaculares e distanciadas das imagens dos "espaços de poder" ou das imagens consagradoras da cidade, da região e do país. (RJ, 2006; 79-80).

E como metodologia para o ensino desta disciplina, propõe o uso de novas linguagens, como a literatura, a música e o cinema. Sendo assim, o documento pretende articular os conceitos gerais aos temas estruturadores do ensino da disciplina propostos pelos PCNs, aos conteúdos selecionados por série, que devem ser utilizado pelos professores como norteadores. E termina comentando que os professores, no trato com os conteúdos, precisam levar em consideração as especificidades de cada escola e dos alunos.

No processo de seriação dos conteúdos, procura justificar o ensino de Geografia do Brasil na $6^{\mathrm{a}}$ série do ensino fundamental e na $3^{\mathrm{a}}$ série do ensino médio, mostrando que nessas séries, o tema Brasil, será o tema central, porém nada impede que o professor trabalhe o tema Brasil em outras séries. Ou ainda, que o ideal é, sempre que possível, partir do "lugar", do contexto em que o educando vive. Seja do estado do Rio de Janeiro ou de uma outra escala de maior vivência e de maior significado. Assim:

Alia-se a tal intenção a possibilidade de trazer para sala de aula a temática do Rio de Janeiro como parte de dinâmicas globais e nacionais. A investigação dirigida para observação do "lugar", das histórias familiares de vida, das trajetórias profissionais ou das formas de trabalho - incluídas aí atividades produtivas no passado e no presente - além da reorganização espacial e política do estado onde vivem são assuntos relevantes e de enorme potencial para o desenvolvimento dos alunos e de suas histórias particulares. Informações contextualizadas ou mesmo de forma desconhecidas tornam-se, então, significativas e a inserção social toma corpo. (RJ, 2006: 80) 
Logo, para que os conteúdos propostos tenham significado, é preciso executar o procedimento de observação e reconhecimento dos lugares e das transformações que os mesmos sofrem.

No final da reorientação para o ensino de Geografia, o mesmo apresenta a proposta de conteúdo programático que, de forma bem sintetizada por nós, se apresenta da seguinte maneira.

\section{Quadro 5}

Distribuição de temas por série

$5^{\mathrm{a}}$ série: O Homem, as paisagens e o Espaço Geográfico. $6^{\mathrm{a}}$ série: O Espaço Brasileiro

$7^{\mathrm{a}} \mathrm{O}$ continente Americano, Oceania e Antártica. $8^{\text {a }}$ Organização do Espaço Mundial

$1^{\text {a }}$ série do Ensino Médio: A Questão Ambiental

$2^{\mathrm{a}}$ série do Ensino Médio: O Mundo em transformação

$3^{\mathrm{a}}$ série do Ensino Médio: O Espaço Geográfico Brasileiro.

E por último, termina com uma listagem de sugestões de vídeos e músicas para auxiliar no processo de ensino-aprendizagem nas escolas. Os vídeos e as músicas são agrupados conforme os temas que a Geografia aborda em aula.

Sobre as concepções de Geografia adotada, nessa parte do documento, mais uma vez, possuímos mais concordâncias do que discordâncias. Dentre as concordâncias ressaltamos a importância do espaço geográfico como categoria central para o estudo desta disciplina, assim como as outras categorias: paisagem, lugar, território, escala, globalização, técnicas e redes. E também que os conteúdos trabalhados devem servir para o desenvolvimento de habilidades e competências e não, simplesmente, servir para desenvolver conhecimentos específicos da Geografia. Para que essa tarefa seja bem desenvolvida, cabe um diálogo desta disciplina com as outras que compõe o currículo escolar fortalecendo a interdisciplinaridade.

Concordamos ainda com o uso de novos procedimentos metodológicos no processo ensino-aprendizagem através do uso de novas linguagens, como a literatura, a música e o cinema e que e os professores no trato com os conteúdos partam da realidade do lugar onde os educandos e as escolas encontram-se inseridos. 
Contudo, nossas discordâncias estão presentes na idéia de Geografia como norteadora na formulação de um currículo interdisciplinar e de "ser a norteadora de um processo de maior conscientização do Mundo que nos cerca". (RJ, 2006; 78). Essa concepção remete a velha idéia da Geografia como "ciência de síntese". Outro ponto de grande polêmica está presente na proposta de seriação, e se a mesma reforça a concepção de Geografia adotada, que exploramos nas próximas páginas deste capítulo.

\subsection{A Reorientação Curricular um contraponto com os DCNEM e os PCNs para o ensino médio.}

Parece um contra-senso, a princípio, fazer uma comparação entre o documento de Reorientação Curricular com os DCNem e os Parâmetros Curriculares Nacionais para o ensino médio construído pelo governo federal através do MEC. Parece contraditório já que o primeiro expressa uma reorientação curricular para o ensino fundamental e médio da educação básica enquanto os dois últimos expressam um conjunto de diretrizes e parâmetros para a educação básica somente na esfera do ensino médio. Porém, quando examinadas de forma minuciosa o documento da Secretaria de Educação do Estado do Rio de Janeiro vemos que, de forma constante, a Reorientação Curricular na sua estrutura traz princípios norteadores dos PCNEM, explicitada, por exemplo, nas primeiras páginas do livro III (Ciências Humanas):

O ponto de partida para modificar esse quadro é sermos todos capazes de reconhecer que há algo errado e que precisamos contribuir para mudar. A partir da Lei de diretrizes e Bases de 1996 (LDBEN 9394/96), o MEC e outros órgãos preocuparam-se em normatizar o preceito legal: São editados os Parâmetros Curriculares Nacionais para o Ensino Fundamental, Os Parâmetros Curriculares Nacionais para o Ensino Médio (PCNEM), as Orientações Educacionais Complementares aos Parâmetros Curriculares Nacionais (PCN+EM), os Referenciais para Formação de Professores, entre outros. (SEEDUC 2006: 15).

Apesar de o documento citar os PCNs para o ensino fundamental e outros documentos que orientam a educação básica brasileira, é a partir dos Parâmetros Curriculares Nacionais para o Ensino Médio e nos (PCN+EM) que a Reorientação Curricular da SEE-RJ mais busca construir seus princípios norteadores, e pensamos que 
isto se deve, em parte, ao perfil das escolas da rede que possuem a maior parte dos seus alunos matriculados no ensino médio.

Para entender como os fundamentos das DCNem e dos PCNem são incorporados ao documento de Reorientação Curricular buscamos entender quais são os princípios norteadores dos primeiros e compará-los ao segundo.

Para Alice Casemiro Lopes (2008) a organização curricular é o grande eixo das mudanças e transformações que o ensino médio sofre no Brasil. Para esta autora, a reforma proposta para este nível de ensino teve a capacidade de construir um discurso associado à mudança no qual, através de propaganda massiva nos meios de comunicação afirmava-se que a educação agora é para a vida, (...) o conhecimento escolar será contextualizado e fará sentido para o aluno. A interdisciplinaridade vai aproximar as disciplinas. O raciocínio e a capacidade de aprender serão mais importantes que a memorização. É com este discurso que se conferiu ao ensino médio através dos parâmetros curriculares a denominação de "novo ensino médio".

Nesse processo de reforma curricular que o ensino médio passou nos últimos dez anos, o discurso sobre organização do conhecimento escolar das Diretrizes Curriculares Nacionais para esse nível de ensino estruturou-se nos conceitos de interdisciplinaridade, contextualização e tecnologias - "hibridizadas à lógica do currículo por competências" (Lopes, 2008: 104). É por este motivo que os PCNEM possuem uma lógica curricular por competências, interdisciplinar e contextualizada.

Lopes (2008) afirma que "desde a sua publicação e distribuição às escolas, as Diretrizes e os Parâmetros Curriculares Nacionais para o ensino médio vem se constituindo como a expressão maior da reforma desse nível de ensino no Brasil" (Lopes, 2008: 93). Reside aí a segunda razão para que os princípios norteadores da Reorientação Curricular estejam nestes documentos.

Uma semelhança da Reorientação Curricular com os Parâmetros reside na arrumação das disciplinas em três grandes áreas do conhecimento tal como nos $\mathrm{PCNEM}^{33}$, e suas respectivas justificativas para integração curricular, além de propor uma maior interdisciplinaridade para com as disciplinas que compõe o currículo e expressar o desejo de que os educandos desenvolvam habilidades e competências.

\footnotetext{
33 Linguagens e Códigos (Livro I), Ciências da Natureza e Matemática (Livro II) e Ciência Humanas (livro III)no documento de Reorientação Curricular e; Linguagens, Códigos e suas tecnologias, Ciências da Natureza, Matemática e suas Tecnologias e Ciências Humanas e suas Tecnologias nos Parâmetros Curriculares Nacionais para o Ensino Médio.
} 
Outro ponto que explica o documento de Reorientação Curricular possuir uma estrutura por grandes áreas do conhecimento reside nas Diretrizes Curriculares para o Ensino Médio no Art. 10 quando este diz que "a base nacional comum dos currículos do ensino médio será organizada em áreas do conhecimento" (Brasil, 2002: 115). São nessas Diretrizes que são apresentadas a área I - Linguagens e Códigos e suas Tecnologias, a área II - Ciências da Natureza, Matemática e suas Tecnologias, a área III - Ciências Humanas e suas Tecnologias e suas respectivas habilidades e competências. Nesse sentido, quando a SEE - RJ construiu a reorientação curricular para o ensino médio, viu-se atrelada as normas instituídas pelo MEC através dos DCNEM.

É neste ponto que reside uma das falhas da Reorientação Curricular, combinar num único documento um currículo para o ensino fundamental e médio, já que conceitos como interdisciplinaridade, contextualização, habilidades e competências são discursos produzidos para o ensino médio e não para o fundamental ${ }^{34}$. Os PCNs para o ensino fundamental não trazem, por exemplo, a idéia de currículo interdisciplinar, mas sim o conceito de transversalidade.

\section{6. A Reorientação Curricular - Uma análise para além dos seus os discursos.}

A análise crítica sobre o documento de Reorientação Curricular foi desenvolvida conforme proposta de Moraes (1998) que afirma que os currículos escolares de Geografia podem ser classificados de duas formas: currículos que possuem coerência interna e os currículos incoerentes.

Um currículo com coerência interna é aquele que possui uma clara "articulação entre os objetivos perseguidos, a sua fundamentação teórica e a matéria tratada. Isto é, as metas e os temas assumidos no plano das intenções se traduzem nos tópicos trabalhados nos programas" (Moraes, 1998:171) Já os currículos incoerentes são aqueles que apresentam um descompasso entre o almejado e o proposto e os conteúdos são descolados da apresentação que o introduz. Possuem incoerência, quando a justificativa dos objetivos apresentados e a explicação metodológica acabam tornandose mera retórica, já que não apresenta relação com a matéria que deveria objetivá-la.

Nesse sentido, fizemos uma análise do documento de Reorientação Curricular buscando identificar seus objetivos, de ordem mais geral, voltados para as escolas; e

\footnotetext{
${ }^{34}$ Cabe ressaltar que o ensino pautado no desenvolvimento de habilidades e competências também aparece nas Diretrizes Nacionais para o Ensino Fundamental.
} 
seus objetivos de ordem mais específica, do ensino de Geografia, para que possamos entender se as metas e os temas assumidos no plano teórico apresentam relação com a programação proposta.

É por esse percurso, partindo dos objetivos e concepções apresentadas na Reorientação Curricular que é proposta a análise. Nosso ponto inicial é dado pelo referido Documento quando esclarece seus objetivos e concepções para o ensino de Geografia e sua contribuição no processo educativo. Posteriormente, articulamos objetivos e concepções com a proposta de desenvolvimento das habilidades e competências que a Geografia deve, segundo o documento, desenvolver na escola. Por último apresentamos os objetivos da Reorientação Curricular enquanto proposta político-pedagógica para as escolas associada a sua programação curricular de Geografia para as séries dos níveis de ensino fundamental e médio.

\subsubsection{Uma análise da Geografia presente na Reorientação Curricular}

Durante a apresentação e introdução ao documento de Reorientação Curricular, explicitadas nas páginas anteriores, percebemos que o mesmo concebe o ensino de Geografia a partir de uma abordagem crítica. Os traços mais marcantes desta concepção de ensino e visão de mundo estão presentes na perspectiva de que o ensino da disciplina precisa partir da realidade dos alunos com o objetivo de fazê-los entender as transformações sofridas pelo espaço geográfico ao longo do tempo, com o intuito de nele poder intervir no seu processo de construção, contribuindo assim para a formação de cidadãos ativos e críticos. Ou seja, entender e/ou construir o conceito de espaço geográfico, segundo o documento, é condição prévia para aprender Geografia.

"A Geografia ensinada promove a compreensão dos alunos a partir dos espaços concretos, físicos, em princípio, os que fazem parte de sua vivência..." (RJ, 2006: 77).

Espera-se ainda que ao aprender esta ciência, os educandos se apropriem do conhecimento científico para formular suas próprias hipóteses sobre a "realidade" e que o professor, ao desenvolver os conceitos da Geografia (espaço geográfico, paisagem, lugar, território, escala, globalização, técnicas e redes) contribua com um importante instrumental teórico para atingir esse objetivo. 
Dentro dessa proposta de um ensino de maior criticidade, cabe ao professor desenvolver, em conjunto com os educandos, os temas da Geografia que estejam comprometidos com a realidade do lugar onde os mesmos estão inseridos. Cabe ainda, aos profissionais desta disciplina, utilizar procedimentos de ensino e pesquisa, como trabalho de campo, para que os alunos desenvolvam "habilidades e competências" de ordem mais geral e também de ordem mais específica da Geografia como o exercício da localização e a comparação entre os lugares.

Estes são, em linhas gerais, os objetivos do ensino de Geografia que a Reorientação Curricular propõe aos professores da rede pública do estado do Rio de janeiro. Um ensino crítico, que parte da realidade do em torno escolar, e que desenvolva habilidades e competências para capacitar os educandos a intervirem no espaço geográfico. Porém, quando o mesmo apresenta o programa curricular, entendemos que tal concepção de ensino não comporta uma proposta de Geografia pautada numa lista de conteúdos resumida e apresentada conforme o Quadro 2.

O resumo deste programa apresenta os conteúdos de uma forma bem seqüenciada série a série. Trata-se de um momento que a organização dos conteúdos se desenvolve em uma ordem predeterminada por princípios da ciência geográfica, que segundo o documento, precisa "possuir uma ordem lógica, que respeite a epistemologia da área de conhecimento, e apresentar claramente as opções metodológicas e conceituais" (RJ, 2006:16).

No entanto, quando analisamos o quadro reproduzido, notamos que essa forma de apresentar a distribuição dos conteúdos pelas séries evidencia uma lógica metodológica que denominamos de clássica, muito difundida na Geografia Tradicional e nos antigos manuais didáticos.

Essa geografia escolar reificada, por exemplo, nos manuais de Aroldo de Azevedo, denominada de Geografia Tradicional, pautou-se pela distribuição dos conteúdos no ensino fundamental da seguinte forma: parte-se de uma Introdução à Geografia, passando num momento posterior ao espaço brasileiro e por último, nas duas séries finais, do continente americano para os demais continentes (Europa, Ásia, África e Oceania). Há elementos suficientes, na Reorientação Curricular para a Geografia, que se perceba como o componente natural (as localização nas placas tectônica, ou os elementos geológicos) determina a distribuição dos conteúdos. Entretanto, diferente dessa organização clássica, há outra forma de distribuição dos conteúdos que tratam, também, de uma introdução à Geografia e da Geografia do Brasil, mas posteriormente 
orienta a análise do espaço geográfico a partir do "mundo industrializado" ou "mundo desenvolvido". A diferença nas formas de apresentar os conteúdos geográficos está na idéia que a Geografia do mundo se torna compreensível a partir de óticas muito distintas - a primeira com forte marca em elementos da natureza e na segunda o espaço está explicitamente marcado pela ação dos povos em suas intervenções na história dos lugares (a ação humana e sua história produzindo paisagens, espaços e condições de existência muito distintas em diferentes regiões do planeta).

A opção de organizar os conteúdos presente no documento de Reorientação Curricular para Geografia busca evidenciar "princípios lógicos” pela primeira opção, pelo recorte geológico dos continentes e não pela intervenção das sociedades que constroem o espaço geográfico. Portanto, entendemos que reside nesta opção de ordem teórico-metodológica, na forma de tratar os conteúdos e temas, uma contradição entre o que foi estabelecido como ensino crítico ou Geografia crítica e os temas selecionados.

Não se trata simplesmente em afirmar que não é possível existir um ensino crítico, partindo de um recorte geológico como o continente Americano ou de um país como o Brasil. Sabemos que é possível um ensino de Geografia crítica partindo de enfoque continental desde que esse seja apenas um ponto de partida. Compreendemos que na atualidade, devemos contemplar por dentro dos programas uma simultaneidade escalar que busque combinar as escalas de análise local/nacional/global. Portanto, "para se realizar tal combinação seria necessário resgatar a idéia de "espaço relacional" e se trabalhar com a moderna noção de rede" (Moraes 1998,172). Contudo, essa idéia não está presente nesta forma de apresentar os recortes, porque os conteúdos listados em cada tema estão estruturados no velho padrão natureza-homem-economia que possui uma limitação para explicar o mundo atual da globalização do capital, como se propõe no Documento.

Um currículo crítico, proveniente das teorias curriculares críticas, não contempla uma programa curricular pré-determinado. Assim como uma Geografia que se diz crítica não comporta uma listagem de conteúdos formulada a revelia dos professores e alunos. Um professor que recebe uma lista de conteúdos conceituais, uma receita e precisa segui-la na íntegra, por princípio, não exerce um ensino crítico e sim tradicional. Quando não há questionamento com o que é ensinado em aula, todo senso de uma pedagogia que se propõe a ser crítica se perde.

É nesse sentido, que o documento de Reorientação Curricular, no nosso entendimento, apresenta proposições críticas nos seus objetivos e propostas 
metodológicas. No entanto, acaba definindo ou encaminhando uma programação de corte bem tradicional para os professores executarem em aula, o que torna a argumentação inicial um exercício de retórica pura já que não apresenta relação com o conteúdo que deveria objetivá-la.

Ainda sobre a programação apresentada, que também é chamado pela Reorientação Curricular, de proposta de seriação, cabe ainda uma análise sobre as argumentações que serviram de critérios sobre a sua escolha.

Dentre os quatro critérios apresentados um foi o que mais nos chamou a atenção por entendermos que este, realmente, foi o único utilizado pelos autores da Reorientação Curricular para formular a programação do ensino de Geografia.

Este critério que deu direção para o ensino desta ciência afirma que foi considerado como relevante na proposta de seriação, o "tratamento dos temas pelos livros didáticos, em especial aqueles que se adaptaram aos PCNs, nos quais além dos textos, estão disponíveis gráficos mapas e tabelas" (RJ, 2006:76).

No entanto, os outros três não aparecem de forma efetiva ou são completamente inexistentes, servindo apenas como retórica, na distribuição dos conteúdos por série. São eles:

- A assimilação dos conteúdos pelos estudantes, a complexidade dos conceitos e temas envolvidos, as habilidades correlatas.

- A diversidade social dos alunos que cursam o ensino fundamental e médio com seus múltiplos interesses.

- As dimensões multiescalares dos processos espaciais, o cotidiano (local) relacionado aos processos desencadeados a partir de decisões extralocais (nacionais e globais) (RJ, 2006: 78).

É no mercado editorial do livro didático e na orientação dos PCNs para o ensino médio que a proposta de programação mais receberá influência. A Reorientação Curricular busca sua formatação na mistura de um conjunto de conteúdos retirados dos livros didáticos.

É na escolha dos recortes regionais utilizados para trabalhar na programação do segundo segmento do ensino fundamental que conseguimos identificar as semelhanças do programa com os manuais mais vendidos pelo mercado editorial do livro didático ${ }^{35}$. Entendemos que esses manuais trazem nos seus conteúdos a Geografia que mais foi

\footnotetext{
${ }^{35}$ Estamos tomando como referência a coleção de livros didáticos dos seguintes autores. Construindo o Espaço - de Elizabeth Auricchio e Igor Moreira e Geografia - Homem e Espaço - de Elian Alabi Lucci.
} 
reificada nas escolas e na prática cotidiana dos professores ao longo da trajetória desta ciência na escola brasileira. Partimos do princípio que são os mais utilizados por serem os mais antigos, datados da década de 1970, como é o caso do manual do professor Elian que, de certa forma, continuou reproduzindo os mesmos conteúdos de Aroldo Azevedo e a mesma geografia positivista reificada no Padrão Natureza-HomemEconomia.

Por exemplo, na $8^{\circ}$ série $^{36}$, o tema geral a ser abordado é o Espaço Mundial que é se assemelha com o título do livro, da mesma série, dos professores/autores, Elizabeth Auricchio e Igor Moreira, - Construindo o espaço mundial. O mesmo pode-se afirmar do título do livro didático para $5^{\circ}$ série do professor/autor Elian Alabi Lucci, - $A$ natureza, o homem e a organização do espaço - também semelhante com o tema geral para esta série. - O Homem, as paisagens e o Espaço Geográfico. Cabe frisar que não é só nos títulos que a seriação assemelha-se aos livros didáticos. Esse paralelo, também é possível de ser fazer por dentro dos temas e conteúdos abordados na seriação.

Na proposta de seriação os conteúdos e temas abordados não fogem à lógica da nossa "tradição geográfica" fruto de uma "tradição seletiva" imposta por grupos hegemônicos que, dentro da Geografia conseguiram reificar conteúdos e saberes, assim como novos conhecimentos de matrizes teórico-metodológicas diversas como visto no primeiro capítulo deste trabalho.

Outra característica importante na formulação da programação para o ensino de Geografia está presente na seriação do ensino médio que ganha seu formato também no mercado editorial, porém, possui forte influência dos PCNEM e dos PCN+EM. Diríamos que fundamentalmente do segundo, que traz uma lista de conteúdos e temas agrupados em três eixos temáticos para o ensino médio - reproduzido no Quadro $\mathrm{n}^{\circ} 6$.

Nesta lista dos PCN+EM há "uma abordagem tradicional dos conteúdos, de forma compartimentalizada e regionalizada, fragmentando conteúdos que são compreendidos se abordados em sua totalidade" (Campos, 2005: 115).

\footnotetext{
${ }^{36} \mathrm{O}$ que corresponde ao $9^{\circ}$ ano atual.
} 
Quadro 6

Sugestões de organização de eixos temáticos em Geografia conforme os PCN+

\begin{tabular}{|c|c|}
\hline \multicolumn{2}{|r|}{ Eixos temáticos } \\
\hline \multicolumn{2}{|r|}{ A dinâmica do Espaço Geográfico } \\
\hline Temas & Subtemas \\
\hline $\begin{array}{l}\text { 1. A fisionomia da superfície } \\
\text { terrestre }\end{array}$ & $\begin{array}{l}\text { - Tempo geológico; tempo histórico } \\
\text { - Dinâmica da litosfera. O relevo } \\
\text { - Dinâmica da superfície hídrica } \\
\text { - Os seres vivos e sua dinâmica }\end{array}$ \\
\hline $\begin{array}{l}\text { 2. As conquistas tecnológicas e a } \\
\text { alteração do equilíbrio natural }\end{array}$ & $\begin{array}{l}\text { - O ser humano, ser natural } \\
\text { - A cultura humana e suas conquistas } \\
\text { - Técnicas; tecnologia. Alteração da paisagem } \\
\text { - O ser humano e a utilização dos recursos naturais }\end{array}$ \\
\hline $\begin{array}{l}\text { 3. Ações em defesa do substrato } \\
\text { natural e da qualidade de vida }\end{array}$ & $\begin{array}{l}\text { - Os problemas ambientais e sua origem } \\
\text { - Grandes catástrofes ambientais e suas causas } \\
\text { - Consciência ambiental. Movimentos e mobilização } \\
\text { - Conferências internacionais. Resistência política. } \\
\text { Os caminhos do problema ambiental }\end{array}$ \\
\hline $\begin{array}{l}\text { 4. Informações e recursos: } \\
\text { representação dos fatos relativos } \\
\text { à dinâmica terrestre }\end{array}$ & $\begin{array}{l}\text { - Recursos disponíveis para o registro de problemas } \\
\text { ambientais } \\
\text { - Teledetecção: satélites a serviço da questão ambiental } \\
\text { - A produção cartográfica sobre a questão ambiental }\end{array}$ \\
\hline \multicolumn{2}{|c|}{ O mundo em transformação: as questões econômicas e os problemas geopolíticos } \\
\hline Temas & Subtemas \\
\hline 1. Um mundo que se abre & $\begin{array}{l}\text { - Redes, técnicas, fluxos } \\
\text { - O fim da Guerra Fria e a expansão do capitalismo } \\
\text { - A ONU como poder decisório em questão } \\
\text { - A moderna diplomacia }\end{array}$ \\
\hline 2. Um mundo que se fecha & $\begin{array}{l}\text { - Desenvolvimento e subdesenvolvimento: } \\
\text { distâncias que aumentam } \\
\text { - Blocos econômicos. Interesses políticos } \\
\text { - Nacionalismos e separatismos } \\
\text { - A América em busca de novos caminhos }\end{array}$ \\
\hline 3. Tensões, conflitos, guerras & $\begin{array}{l}\text { - Oriente Médio } \\
\text { - A África: seus problemas e suas soluções } \\
\text { - Novos rumos do Leste Europeu } \\
\text { - Ásia do Sul e do Sudeste }\end{array}$ \\
\hline 4. Mapas, índices, taxas & $\begin{array}{l}\text { - Documentando o mundo político. Os mapas. Os gráficos } \\
\text { - Índices de desempenho e sua utilização } \\
\text { - A representação do local e do global } \\
\text { - O mapa como instrumento ideológico }\end{array}$ \\
\hline \multicolumn{2}{|c|}{ O homem criador de paisagem/modificador do espaço } \\
\hline Temas & Subtemas \\
\hline $\begin{array}{l}\text { 1. O espaço geográfico } \\
\text { produzido/apropriado }\end{array}$ & $\begin{array}{l}\text { - O espaço das técnicas: sistemas de objetos; sistemas de ações } \\
\text { - Fluxos, estradas, redes de comunicação } \\
\text { - A produção e o uso da energia } \\
\text { - Divisão internacional do trabalho e da produção }\end{array}$ \\
\hline
\end{tabular}




\begin{tabular}{|c|c|}
\hline 2. A paisagem rural & $\begin{array}{l}\text { - O meio rural tradicional } \\
\text { - O campo e a invasão do capital industrial } \\
\text { - Produção agrícola e tecnologia } \\
\text { - Produção agrícola e persistência da fome }\end{array}$ \\
\hline 3. A paisagem urbana & $\begin{array}{l}\text { - A cidade como espaço de transformação industrial } \\
\text { - A cidade prestadora de serviços } \\
\text { - Metrópoles. Metropolização } \\
\text { - Problemas urbanos. Serviços básicos na cidade }\end{array}$ \\
\hline $\begin{array}{l}\text { 4. A população mundial: } \\
\text { estrutura, dinâmica e problemas }\end{array}$ & $\begin{array}{l}\text { - Ricos e pobres. A concentração das riquezas. A fome } \\
\text { e as doenças } \\
\text { • Etnias, religiões, culturas } \\
\text { - Migrações. A população em movimento } \\
\text { - A população e o acesso aos bens produzidos }\end{array}$ \\
\hline \multicolumn{2}{|c|}{ O território brasileiro: um espaço globalizado } \\
\hline Temas & Subtemas \\
\hline $\begin{array}{l}\text { 1. Nacionalidade e identidade } \\
\text { cultural }\end{array}$ & $\begin{array}{l}\text { - População brasileira e sua identidade } \\
\text { - Crescimento populacional e dinâmica: migrações } \\
\text { - Urbanização. Periferização } \\
\text { - Transformações culturais da população brasileira } \\
\text { - As minorias étnicas e sua integração na sociedade brasileira }\end{array}$ \\
\hline $\begin{array}{l}\text { 2. A ocupação produtiva do } \\
\text { território }\end{array}$ & $\begin{array}{l}\text { - O campo brasileiro e suas transformações } \\
\text { - Os caminhos da industrialização brasileira } \\
\text { - O delineamento e a estrutura da questão energética no Brasil } \\
\text { - As cidades brasileiras e a prestação de serviços }\end{array}$ \\
\hline $\begin{array}{l}\text { 3. O problema das comunicações } \\
\text { num território muito extenso }\end{array}$ & $\begin{array}{l}\text { - O modelo brasileiro de rede de transportes } \\
\text { - O transporte nas áreas urbanas e metropolitanas } \\
\text { - A circulação de valores e do pensamento. } \\
\text { O Brasil no contexto internacional } \\
\text { - Transportes, comunicações e integração nacional }\end{array}$ \\
\hline
\end{tabular}

Fonte: Brasil, 2002: 66-68 
Não queremos afirmar que a reorientação curricular para a geografia é cópia na integra dos temas e subtemas listados nos PCN+EM. Embora os subtemas não sejam exatamente iguais, os temas gerais de cada série do ensino médio são muito semelhantes. Observe-se o quadro comparativo.

Quadro 7

Quadro comparativo: Reorientação Curricular - PCN+EM

\begin{tabular}{|c|c|}
\hline Reorientação Curricular & $\mathrm{PCN}+\mathrm{EM}$ \\
\hline $\begin{array}{l}1^{\circ} \text { Serie do Ensino Médio: A questão } \\
\text { Ambiental }\end{array}$ & A dinâmica do espaço geográfico \\
\hline $\begin{array}{l}2^{\circ} \text { Serie do Ensino Médio: O Mundo em } \\
\text { Transformação }\end{array}$ & $\begin{array}{l}\text { O mundo em transformação: as questões } \\
\text { econômicas e os problemas geopolíticos }\end{array}$ \\
\hline $\begin{array}{c}3^{\circ} \text { Serie do Ensino Médio: O Espaço } \\
\text { Geográfico Brasileiro }\end{array}$ & $\begin{array}{l}\text { O território brasileiro: um espaço } \\
\text { globalizado }\end{array}$ \\
\hline
\end{tabular}

Diante do quadro exposto sobre os critérios que construíram a programação, torna-se transparente que a Reorientação Curricular usa como fórmula para construir o programa de Geografia para a educação básica elementos de livros didáticos da Geografia Tradicional, inclusive que utiliza os recortes geológicos na seriação do ensino fundamental e os temas abordados pelos PCN+EM .

Se a Reorientação Curricular propõe um ensino de Geografia com maior criticidade por parte dos professores e espera por parte dos educandos um pensamento crítico e uma maior autonomia intelectual, entendemos que não é aprendendo um número significativo de conteúdos conceituais tais objetivos ocorrerão. Os conteúdos quando selecionados precisam, além dos seus fundamentos e intenções, considerar as condições objetivas e subjetivas do corpo discente.

Se Reorientação Curricular possuísse como princípio norteador a autonomia do trabalho dos professores, não apresentaria uma lista fechada de conteúdos, mas sugestões para que os mesmos desenvolvessem seu planejamento podendo escolher aqueles mais propícios ou favoráveis. Um currículo que apresentasse eixos organizadores dos temas da Geografia permitiria aos profissionais da rede maior autonomia na seleção de seus conteúdos.

Contudo, essa opção é justificada quando no Documento afirma-se que um dos maiores problemas apresentados pela rede pública estadual de ensino "relaciona-se à seriação dos conteúdos programáticos. A ausência de um "padrão de referência" tanto 
dificulta a transferência de alunos vinda de outras escolas, ou mesmo de outros estados, quanto dificulta o trabalho docente" (RJ, 2006: 79).

Um planejamento comum a todas as escolas para resolver o "grande problema $^{37, " ~ d a ~ e d u c a c ̧ a ̃ o ~ p u ́ b l i c a . ~ O ~ o b j e t i v o ~ e ́ ~ q u e ~ t o d a s ~ a s ~ e s c o l a s, ~ t o d o s ~ o s ~}$ professores e os alunos sigam uma mesma seqüência. O Documento traz uma visão ensino que deve padronizar as escolas e uniformizar a educação. Essa uniformização deve ser pautada no conhecimento acadêmico, através dos conteúdos mais tradicionais desta ciência. Essa concepção de educação, mais uma vez não, coaduna com uma visão de educação crítica, de um ensino crítico em Geografia, conforme afirma Vesentini.

É por isso que, no ensino crítico, não é possível que o docente elabore o seu planejamento de curso sem conhecer a realidade (econômico, social, intelectual) dos alunos e do meio onde vivem; tampouco é possível que "programas oficiais" sejam levados a sério ou seguidos rigidamente - no máximo eles poderão ser encarados como "sugestões" que, dessa forma, podem e devem ser rediscutidos e reelaborados.

Ora dirão alguns, mas e a unificação do conhecimento e o problema dos alunos que se transferem de uma a escola para outra? Uma característica atual do pensamento crítico e mesmo de democracia e pluralidade de opções e experiências, com a conseqüente recusa da unificação (que é sempre cara às mentes autoritárias e aos regimes totalitários). (Vesentini, 1992: 56)

$\mathrm{Na}$ verdade, subjacente a esta idéia, de que todos os professores devem seguir uma mesma programação e uma mesma seqüência de conteúdos, está presente a concepção de currículo tradicional, no qual todos - alunos e professores - devem perseguir os mesmos objetivos, através dos mesmos conteúdos, procedimentos e métodos, a fim de alcançar determinadas metas e mensurá-las. Essa perspectiva de currículo deve ainda, considerar a distribuição do tempo das aulas e as relações burocráticas da escola para que todas as metas e objetivos sejam alcançadas. Esses procedimentos de ensino padronizados inviabilizam a construção de um ensino Geografia que investigue o "espaço real do aluno" e não permite ao professor um planejamento mais flexível e menos burocrático.

\footnotetext{
${ }^{37}$ No entendimento do SEPE os grandes problemas da rede pública são outros, mais significativos e relevantes como: a ausência de infra-estrutura nas escolas, carência de escolas em determinadas regiões, os baixos salários pagos aos professores, a desvalorização e a sobrecarga de trabalho dos profissionais da rede.
} 
Já na perspectiva de uma educação crítica a proposta de seriação através de uma listagem de conteúdos não é essencial e prioritária, já que os conteúdos são instrumentos para atingir determinadas atitudes cognitivas como afirma Vesentini:

(...) o que mais vale para o ensino moderno são as atitudes cognitivas (raciocínio lógico, criticidade, etc.), e não o conhecimento em si que, na realidade, é sobretudo um instrumento para desenvolver certas potencialidades do educando. (Vesentini, 1992: 56).

O autor ainda explora e denuncia outra questão que explica as propostas de currículos que buscam uniformizar a educação que no nosso entendimento é o verdadeiro objetivo da Reorientação Curricular.

(...) estabelecer um programa de cima para baixo nada mais é do que uma forma de controle social sobre os professores (na medida em que esses passam a ser meros reprodutores de conhecimentos elaborados noutro lugar) e sobre os alunos (pois um professor que apenas reproduz conhecimentos já prontos nunca vai contribuir para que o educando seja co-autor do saber, sendo mais um obstáculo para o desenvolvimento da criatividade do aluno). (Vesentini, 1992: 57)

Exercer um grande controle sobre as escolas, professores e alunos. Esse é o grande e verdadeiro objetivo deste documento e a Geografia proposta se insere neste contexto de controle social, uma disciplina com base no recortes regionais, no padrão N-H-E, e conceitual no sentido do conceito científico pronto. Essa Geografia não considera o caráter histórico dos sujeitos e da produção do conhecimento nos processos pedagógicos mais ativos e dialógicos.

\subsubsection{Os saberes da Geografia e as habilidades e competências.}

Outro aspecto de grande relevância para avaliarmos a coerência teórica do documento de Reorientação Curricular, tratada no programa desta disciplina, está presente quando o Documento "fala" que um dos seus principais objetivos é desenvolver habilidades e competências para instrumentalizar o aluno a um maior entendimento do Mundo.

De acordo com o Documento os saberes que a Geografia promove na escola devem ser pautados no desenvolvimento das habilidades e competências e que os 
conteúdos devem ser instrumentos para alcançar esses objetivos. Essa forma de pensar sobre o papel das habilidades e competências é o que mais tem se reificado nas escolas.

Para nós, esse entendimento é de grande relevância devido à natureza do tema. Afinal, desenvolver habilidades e competências é algo que se encontra em voga nas questões curriculares atuais, e esse par, junto com a interdisciplinaridade, é o que mais tem se preconizado nas recentes reformas curriculares brasileiras e nos instrumentos de avaliação do ensino médio como o ENEM.

No documento de Reorientação Curricular para Geografia, as competências e habilidades aparecem em dois momentos. No primeiro momento, o tema é abordado na sua parte de fundamentação teórica - que expõe sobre "Os saberes da Geografia" no subtítulo "Por que Ensinar Geografia" (RJ, 2006: 75) - e depois na listagem de conteúdos para cada série da educação básica.

Nesse primeiro momento "as competências foram sintetizadas tendo em vista as práticas mais imediatas dos professores" (RJ, 2006: 76), sem a devida explicação de que prática são essas. E devido a essas práticas promoveu-se "um recorte em relação ao vasto conjunto de competências e habilidades" (RJ, 2006: 76) proposta pela LDBN 9394/96 e pelos PCNs.

\section{Quadro 8}

Reorientação Curricular - Competências e habilidades a serem desenvolvidas em Geografia.

\section{Competência e Habilidades Pretendidas com o Ensino de Geografia.}

As competências foram sintetizadas em vista as práticas mais imediatas dos professores. Promovem um recorte em relação ao vasto conjunto de competências e habilidades propostas pela Lei de Diretrizes e Bases (LDBEN 9394/96) e às indicações sugeridas pelos Parâmetros Curriculares Nacionais (PCNs).

Assim, ao longo de sua escolarização, espera-se possibilitar ao aluno.

- Adquirir o pleno domínio da linguagem cartográfica (croquis, mapas, gráficos, imagens de satélites, etc.) como forma de representar o espaço os fatos e os fenômenos no espaço geográfico.

- Dominar as noções de escala (cartográfica e geográfica) no conhecimento geográfico.

- Comparar os fenômenos geográficos e reconhecer as diferenças e as semelhanças existentes entre eles.

- Identificar singularidades e generalidades de uma paisagem, lugar ou território no espaço.

$\mathrm{Na}$ verdade quando comparamos esse quadro que sintetiza as habilidades e competências a serem desenvolvidas pelos professores na educação básica, com o quadro apresentado pelos PCNEM, percebemos que há uma simplificação ou mesmo uma cópia reduzida do original conforme exposto na seqüência (vide Quadro 11) 
No segundo momento em que aparecem as habilidade e competências, essas surgem de forma muito específica, pautadas através de uma listagem de conteúdos. Ou seja, neste momento as habilidades e as competências são condicionadas para cada tema trabalhado e os mesmos desdobram-se em conteúdos específicos da Geografia. Vejamos como elas aparecem, utilizando como exemplo uma parte do programa para a $3^{\circ}$ série do Ensino Médio e outra da antiga $5^{\circ}$ série do Ensino Fundamental. 


\section{Quadro 9}

Reorientação Curricular / SEE-RJ - proposta de seriação. $3^{\circ}$ ano do Ensino Médio

\begin{tabular}{|c|c|c|c|c|}
\hline TEMA & $\begin{array}{l}\text { COMPETÊNCIAS E } \\
\text { HABILIDADES }\end{array}$ & CONTEÚDOS & $\begin{array}{l}\text { SUGESTÕES DE } \\
\text { ATIVIDADES }\end{array}$ & INTERFACE \\
\hline $\begin{array}{l}\text { BRASIL } \\
\text { AGRÁRIO }\end{array}$ & $\begin{array}{l}\text { - Caracterizar e } \\
\text { compreender os } \\
\text { principais problemas } \\
\text { do espaço agrário } \\
\text { brasileiro }\end{array}$ & $\begin{array}{l}\text { - Principais } \\
\text { características do } \\
\text { espaço agrário } \\
\text { brasileiro e as novas } \\
\text { tecnologias no campo } \\
\text { / política ambiental } \\
\text { - Política Agrária e } \\
\text { movimentos sociais }\end{array}$ & $\begin{array}{l}\text { - Leitura de textos } \\
\text { diversos e discussão } \\
\text { sobre temas como: } \\
\text { Transgênicos } \\
\text { /movimentos sociais; } \\
\text { conflitos ambientais; } \\
\text { destino do Lixo }\end{array}$ & $\begin{array}{l}\text { - Português } \\
\text { - Biologia } \\
\text { - Filosofia }\end{array}$ \\
\hline $\begin{array}{l}\text { BRASIL } \\
\text { INDUSTRIAL }\end{array}$ & $\begin{array}{l}\text { - Relacionar as } \\
\text { formas de apropriação } \\
\text { do espaço pelo } \\
\text { homem e os } \\
\text { problemas ambientais } \\
\text { causadas por estas } \\
\text { atividades }\end{array}$ & $\begin{array}{l}\text { • Processo de } \\
\text { industrialização (fase } \\
\text { pré-industrial, } \\
\text { substituição de } \\
\text { importações, } \\
\text { internacionalização e } \\
\text { fase } \\
\text { atual). } \\
\text { • Concentração e } \\
\text { dispersão } \\
\text { industrial } \\
\text { • Estrutura industrial } \\
\text { brasileira e questão } \\
\text { ambiental }\end{array}$ & $\begin{array}{l}\text { - Elaborar trabalho } \\
\text { em grupo a partir de } \\
\text { artigos variados de } \\
\text { jornal mostrando o } \\
\text { setor industrial } \\
\text { brasileiro em seus } \\
\text { múltiplos aspectos } \\
\text { - Discutir o protocolo } \\
\text { de Quioto, a ação das } \\
\text { diversas Ongs e } \\
\text { outras questões } \\
\text { ligadas a poluição de } \\
\text { origem industrial. }\end{array}$ & $\begin{array}{l}\text { - Português } \\
\text { - Biologia } \\
\text { - Filosofia } \\
\text { - Matemática } \\
\text { - Física }\end{array}$ \\
\hline $\begin{array}{l}\text { A } \\
\text { CIRCULAÇÃO } \\
\text { DE } \\
\text { IDÉIAS, } \\
\text { PESSOAS E } \\
\text { PRODUTOS NO } \\
\text { BRASIL }\end{array}$ & $\begin{array}{l}\text { - Compreender as } \\
\text { mudanças ocorridas } \\
\text { no espaço geográfico } \\
\text { em função da } \\
\text { aquisição de novas } \\
\text { tecnologias de } \\
\text { transportes e } \\
\text { telecomunicações }\end{array}$ & $\begin{array}{l}\text { - Transportes - } \\
\text { principais vias e meios } \\
\text { /transporte } \\
\text { urbano/política } \\
\text { ambiental } \\
\text { - Difusão de } \\
\text { informações: } \\
\text { circulação de idéias }\end{array}$ & $\begin{array}{l}\text { - Trabalhar com } \\
\text { mapas analisando e } \\
\text { comparando } \\
\text { diferentes redes de } \\
\text { transportes, seus usos } \\
\text { e } \\
\text { distribuições } \\
\text { - Trabalhar com } \\
\text { música de temática } \\
\text { relacionada ao } \\
\text { assunto em estudo }\end{array}$ & $\begin{array}{l}\text { - Português } \\
\text { - Sociologia } \\
\text { - História }\end{array}$ \\
\hline
\end{tabular}

(RJ, 2006: 102) 


\section{Quadro 10}

Reorientação Curricular - proposta de seriação. $5^{\circ}$ série do Fundamental (atual $6^{\circ}$ série)

\begin{tabular}{|c|c|c|c|c|}
\hline TEMA & $\begin{array}{l}\text { COMPETÊNCIAS E } \\
\text { HABILIDADES }\end{array}$ & CONTEÚDOS & $\begin{array}{l}\text { SUGESTÕES DE } \\
\text { ATIVIDADES }\end{array}$ & INTERFACE \\
\hline $\begin{array}{l}\text { AS PAISAGENS } \\
\text { E O ESPAÇO } \\
\text { GEOGRÁFICO }\end{array}$ & $\begin{array}{l}\text { - Compreender as } \\
\text { diferentes paisagens } \\
\text { terrestres. }\end{array}$ & $\begin{array}{l}\text { - Conceito de } \\
\text { paisagem. } \\
\text { - Tipos de paisagem. } \\
\text { - Conceito de espaço } \\
\text { geográfico }\end{array}$ & $\begin{array}{l}\text { - Desenhar os } \\
\text { diferentes tipos de } \\
\text { paisagens. } \\
\text { - Produzir um painel } \\
\text { com as paisagens do } \\
\text { bairro onde se } \\
\text { localiza a escola. }\end{array}$ & $\begin{array}{l}\text { - Português } \\
\text { - Artes }\end{array}$ \\
\hline ATMOSFERA & $\begin{array}{l}\text { - Distinguir tempo de } \\
\text { clima. } \\
\text { - Identificar } \\
\text { problemas } \\
\text { ambientais. }\end{array}$ & $\begin{array}{l}\text { - Conceito de tempo e } \\
\text { clima. } \\
\text { - Elementos do clima. } \\
\text { - Efeitos da ação do } \\
\text { homem sobre a } \\
\text { atmosfera. } \\
\text { - Conceito de } \\
\text { ecossistema. }\end{array}$ & $\begin{array}{l}\text { - Gráfico de } \\
\text { temperaturas } \\
\text { máximas e } \\
\text { mínimas. } \\
\text { - Pesquisa sobre } \\
\text { poluição atmosférica. }\end{array}$ & $\begin{array}{l}\text { - Português } \\
\text { - Ciências } \\
\text { - Matemática } \\
\text { - História }\end{array}$ \\
\hline $\begin{array}{l}\text { A LITOSFERA } \\
\text { E O RELEVO } \\
\text { TERRESTRE }\end{array}$ & $\begin{array}{l}\text { - Relacionar as } \\
\text { formas de apropriação } \\
\text { do espaço pelo } \\
\text { homem e os } \\
\text { problemas ambientais } \\
\text { causadas por estas } \\
\text { atividades }\end{array}$ & $\begin{array}{l}\text { - Relevo terrestre. } \\
\text { - A estrutura interna da } \\
\text { Terra e a crosta } \\
\text { terrestre. } \\
\text { - Relevo e suas formas. } \\
\text { - As forças } \\
\text { modificadoras do } \\
\text { relevo. }\end{array}$ & $\begin{array}{l}\text { - Coletar e classificar } \\
\text { rochas da região. } \\
\text { - Fazer maquete. }\end{array}$ & $\begin{array}{l}\text { - Português } \\
\text { - Ciências } \\
\text { - Artes }\end{array}$ \\
\hline $\begin{array}{l}\text { A ATIVIDADE } \\
\text { INDUSTRIAL E } \\
\text { AS FONTES DE } \\
\text { ENERGIA }\end{array}$ & $\begin{array}{l}\text { - Distinguir recursos } \\
\text { renováveis e não } \\
\text { renováveis. } \\
\text { - Reconhecer a } \\
\text { importância de um } \\
\text { desenvolvimento } \\
\text { sustentável. } \\
\text { - Distinguir os tipos de } \\
\text { atividades industriais. } \\
\text { - Distinguir as fontes de } \\
\text { energia. } \\
\text { - Identificar os efeitos } \\
\text { da industrialização: } \\
\text { poluição do ar, da água } \\
\text { e do solo, e suas } \\
\text { consequiências para o } \\
\text { meio ambiente e para a } \\
\text { qualidade de vida. }\end{array}$ & $\begin{array}{l}\text { - Os recursos naturais e o } \\
\text { Desenvolvimento } \\
\text { sustentável. } \\
\text { - A atividade industrial e } \\
\text { os tipos de } \\
\text { indústrias. } \\
\text { - As fontes de energia. } \\
\text { - A industrialização. }\end{array}$ & $\begin{array}{l}\text { - Fazer um painel com } \\
\text { as notícias das industrias } \\
\text { do município. } \\
\text { - Montar um relatório } \\
\text { das indústrias } \\
\text { mais poluentes. }\end{array}$ & $\begin{array}{l}\text { - Português } \\
\text { - Ciências } \\
\text { - História }\end{array}$ \\
\hline
\end{tabular}

(RJ, 2006: 82) 
Através do que é apresentado nos quadros, é possível perceber que todas as habilidades e competências iniciam-se com um verbo (identificar, distinguir, reconhecer, compreender, relacionar e caracterizar), entretanto, não fica claro para o professor se o que é exposto são habilidades ou competências e o que diferencia uma da outra conceituando-as de uma melhor forma.

Isto é um indicativo para discutirmos um pouco sobre as idéias de habilidades e competências numa tentativa de compreender melhor esse tema para que possamos fazer uma análise com maior clareza acerca do mesmo. Entretanto, em vez de partir diretamente para uma tentativa de apenas diferencia-las com o objetivo de conceituá-las, vamos primeiramente, contextualiza-las nas reformas curriculares brasileiras para que possamos entender melhor as divergências sobre esse tema.

Para compreender o currículo baseado em habilidades e competências, Lopes (2008) oferece subsídios pertinentes quando analisa as reformas educacionais brasileiras inseridas no contexto das Diretrizes Curriculares Nacionais e sobre os Parâmetros Curriculares Nacionais para o ensino médio.

Para esta autora, o discurso oficial sobre organização do conhecimento escolar das atuais reformas curriculares brasileiras se faz dentro da ótica de um currículo integrado. No entanto, para que tal perspectiva curricular se tornasse viável no Brasil, foi necessário implantar em nossa cultura escolar, que é disciplinar, os conceitos de interdisciplinaridade, contextualização e tecnologias - hibridizadas à lógica do currículo por competências. É a partir desses conceitos que se elabora um discurso que busca recontextualizar as idéias de um currículo integrado defendidas nesse campo do conhecimento.

Para expressar o enfoque interdisciplinar no nível médio, os Parâmetros Curriculares Nacionais, organizam as três áreas com seus respectivos conhecimentos disciplinares. O documento justifica a divisão em áreas dizendo que "tem por base a reunião daqueles conhecimentos que partilham objetos de estudos e, portanto, mais facilmente se comunicam, criando condições para que a prática escolar se desenvolva numa perspectiva interdisciplinaridade" (Brasil, 1999 apud Lopes, 2008: 109). Nesse caso convivem interdisciplinaridade e disciplinas.

No entanto, as DCNEM também não se propõem a questionar as disciplinas e os conteúdos trabalhados no ensino médio. Na verdade o que a diretrizes propõe são: criar novas possibilidades de programação para este nível de ensino, que a escola incorpore 
conhecimentos que permitam uma leitura crítica do mundo e uma organização curricular que busque:

- Desbastar o currículo enciclopédico, congestionado de informações, priorizando conhecimentos e competências de tipo geral, que são prérequisito tanto para inserção profissional mais precoce quanto para continuidade de estudos, entre as quais se destaca a capacidade de continuar aprendendo;

- (res)significar os conteúdos curriculares como meios para constituição de competências e valores, e não como objetivos do ensino em si mesmo (Brasil, 2002: 87).

Às competências caberia a integração das disciplinas e dos conteúdos e dar novos sentidos a ambos. São as competências que vão orientar a seleção de conteúdos dentro de cada disciplina. No entanto, a organização do currículo por competência não é disciplinar, já que as habilidades e competências a serem formadas exigem conteúdos de diferentes disciplinas. Sua organização, via de regra, é feita por módulos e cada módulo engloba conteúdos e atividades capazes de formar determinado conjunto de habilidades.

Para Lopes (2008), o conceito de habilidades e competências, no Brasil, passa por um processo de descontextualização e posteriormente, por um processo de recontextualização por hibridismos ${ }^{38}$. Isto ocorre porque, inicialmente, os textos que foram produzidos em diversos contextos externos a nossa realidade educacional, foram selecionados em detrimento de outros e são deslocados para questões específicas, práticas e relações sociais distintas, pertencentes à realidade educacional brasileira. Simultaneamente, há um reposicionamento e uma refocalização desses textos. Os textos são simplificados pelos processos de simplificação, condensação e reelaboração, desenvolvidos em meio a conflitos entre os diferentes interesses que estruturam o campo de recontextualização.

Ainda de acordo com Lopes (2001, 2008), as políticas curriculares nacionais, ainda que se baseiem em princípios reguladores de controle e de poder externos, vindos de organismos multilaterais como o BID e o Banco Mundial, não são desenvolvidos como mera reprodução das diretrizes internacionais.

\footnotetext{
${ }^{38}$ Para Alice Casemiro Lopes $(2001,2008)$ a recontextualização por mecanismos de hibridização não expressa um sentido de adulterar textos supostamente originais. A própria idéia de originalidade se modifica, pois, dada a rapidez com que novos textos são incorporados e com que suas marcas são, não se tem precisão do que se defende como original. Isso não significa, contudo, a simples exaltação da hibridização, sem a devida análise de quais são os novos significados instituídos pelos produtos culturais híbridos formados.
} 
Processos de recontextualização ocorrem, seja pela atuação dos campos de produção e de controle simbólico nacionais, seja pela atuação do campo recontextualizador pedagógico do país em questão, seja ainda pelas tensões características específicas do campo recontextualizador oficial nacional e dos contextos escolares"(Lopes, 2008: 30).

Nesse sentido a tensão global-local constantemente se estabelece nos processos de recontextualização, criando uma nova leitura sobre os textos e recriando novos textos por um processo de hibridização.

E por isso que, para resolver e equacionar a organização curricular disciplinar, que historicamente sempre existiu no Brasil, adota-se, no caso dos PCNEM, um currículo integrado por competências. Esse currículo possui como norte a interdisciplinaridade e a contextualização distribuídas em três áreas do conhecimento.

Sendo assim, as competências, que não dependem de saberes disciplinares, se articulam nos PCNem com as disciplinas, que pressupõe uma determinada seleção de conteúdos, e com a interdisciplinaridade, que pressupõe a inter-relação de disciplinas. Esse caráter ambíguo tornase mais explicito na medida em que os PCNem apresentam listagem de competências e habilidades para cada área e para cada disciplina, parecendo conferir uma caráter disciplinar às competências específicas. (Lopes, 2008: 136).

Também é por esse motivo que os professores de Geografia conseguem identificar facilmente, os conteúdos que devem ser tratados no ensino médio para esta disciplina afinal, as competências e habilidades listadas são rapidamente associadas aos conteúdos tratados historicamente, na escola, por esta ciência. Porém, o que fica faltando nesta listagem é indicar o momento, na vida escolar do aluno, em que ele precisa desenvolver determinadas habilidades e competências. Vejamos na seqüência. 


\title{
QUADRO 11
}

\section{Parâmetros Curriculares Nacionais para o Ensino Médio - competências e habilidades a serem desenvolvidas em Geografia.}

\author{
Representação e comunicação \\ - Ler, analisar e interpretar os códigos específicos da Geografia (mapas, gráficos, tabelas etc.), \\ considerando-os como elementos de representação de fatos e fenômenos espaciais e/ou espacializados.
}

- Reconhecer e aplicar o uso das escalas cartográfica e geográfica, como formas de organizar e conhecer a localização, distribuição e frequiência dos fenômenos naturais e humanos.

\section{Investigação e compreensão}

- Reconhecer os fenômenos espaciais a partir da seleção, comparação e interpretação, identificando as singularidades ou generalidades de cada lugar, paisagem ou território.

- Selecionar e elaborar esquemas de investigação que desenvolvam a observação dos processos de formação e transformação dos territórios, tendo em vista as relações de trabalho, a incorporação de técnicas e tecnologias e o estabelecimento de redes sociais.

- Analisar e comparar, interdisciplinarmente, as relações entre preservação e degradação da vida no planeta, tendo em vista o conhecimento da sua dinâmica e a mundialização dos fenômenos culturais, econômicos, tecnológicos e políticos que incidem sobre a natureza, nas diferentes escalas - local, regional, nacional e global.

\section{Contextualização sócio-cultural}

- Reconhecer na aparência das formas visíveis e concretas do espaço geográfico atual a sua essência, ou seja, os processos históricos, construídos em diferentes tempos, e os processos contemporâneos, conjunto de práticas dos diferentes agentes, que resultam em profundas mudanças na organização e no conteúdo do espaço.

- Compreender e aplicar no cotidiano os conceitos básicos da Geografia.

- Identificar, analisar e avaliar o impacto das transformações naturais, sociais, econômicas, culturais e políticas no seu "lugar-mundo", comparando, analisando e sintetizando a densidade das relações e transformações que tornam concreta e vivida a realidade.

(Brasil, 2002: 315) 
Para Lopes (2008) os PCNs não apresentam discussões e análises de conteúdos mais amplos, focalizando especialmente a organização curricular em detrimento da seleção de conteúdos. Esses tendem a ser subsumidos às competências. Interessam os conteúdos que permitam a formação das competências e das habilidades previstas no quadro acima. Nesse sentido as competências tornam-se abrangentes, podendo o professor definir os conteúdos que se deseja trabalhar para alcançá-las. Por exemplo. Quais os conteúdos na ciência geográfica que vão ajudar, a construir as habilidades e competências de "ler, analisar e interpretar os códigos específicos da Geografia (mapas, gráficos, tabelas etc.), considerando-os como elementos de representação de fatos e fenômenos espaciais e/ou espacializados" (Brasil, 2002: 135)?

Ler, analisar e interpretar códigos é uma habilidade que pode ser desenvolvida com o processo de codificação e de decodificação que o professor pode trabalhar com os alunos através do ensino dos seguintes conteúdos: leitura de símbolos e escalas. Também cabe o professor definir qual o mapa utilizado, do bairro onde o educando mora ou de outra região do planeta. Entretanto, o objetivo final é ler e interpretar os códigos da Geografia em qualquer outra representação do mundo construído por esta ciência.

Essa perspectiva de abordar os conteúdos e conceber o ensino permeia os documentos que tratam da reforma do ensino médio no Brasil. Por exemplo, na apresentação do documento de fundamentação teórico-metodológica do ENEM o mesmo argumenta que o exame "focaliza especificamente as competências e habilidades básicas desenvolvidas, transformadas e fortalecidas com a mediação escolar" (INEP, 2005) e reafirma que os conteúdos são instrumentos que levarão a determinados fins (habilidades e competências) e não aos objetivos em torno de si mesmo. É nesse sentido que a matriz curricular do ENEM foi construída através de uma associação entre conteúdos, competências e habilidades básicas. Sendo assim, o documento apresenta a definição das habilidades e competências da seguinte maneira.

Competências cognitivas são as modalidades estruturais da inteligência ações e operações que o sujeito utiliza para estabelecer relações entre os objetos, situações, fenômenos e pessoas que deseja conhecer. As habilidades instrumentais referem-se, especificamente, ao plano do "saber fazer" e decorrem diretamente do nível estrutural das competências já a adquiridas e que se transformam em habilidades. (Matrizes Curriculares de Referências do Saeb, 1998 apud INEP) 
Portanto, segundo os documentos oficiais, a noção de competência está associada à ação, à inteligência prática, a um saber-fazer, não sendo, desta forma, conteúdos em si. Porém, como se define o conceito de habilidade e competências, de tal forma que fique mais claro ao professor?

Segundo Lino de Macedo (2005), existem três formas de pensar o conceito de competências: a) a competência como condição prévia do sujeito, b) a competência como condição prévia do objeto e c) a competência relacional. Na primeira forma de competência (competência do sujeito), o autor afirma que esta é herdada e adquirida, os indivíduos já possuem, como se fosse uma condição prévia, e cita como exemplo o ato de caminhar, respirar e de desenvolver uma língua. São competências inerentes ao sujeito que cedo ou tarde acabam sendo desenvolvidas. A segunda forma de competência, (competência do objeto) refere-se à competência da máquina ou de um objeto próprio. São exemplos de competências dos objetos: A potência de um motor, a qualidade de um livro ou material didático bem construído do ponto de vista metodológico, ou então a qualidade que se atribui aos itens de uma prova que não se relacionam com a competência ou habilidade dos que a respondem. Esse tipo de competência é atributo do objeto e independe do sujeito que o utiliza. Por último, temos a competência relacional, que segundo conta o autor é a mais importante. Essa competência é interdependente das outras e expressa um jogo de interações. Para compreender essa forma de competência, Lino de Macedo, exemplifica e a ilustra através da representação de uma partida de futebol e de uma conferência.

Numa partida de futebol, para fazer gol, não basta que o jogador saiba chutar a gol, fazer embaixadas, correr com a bola no pé, é necessário que saiba coordenar tudo isso no momento da partida.

No caso de uma conferência, a qualidade do texto (competência do objeto) não é condição suficiente para que ela atinja os objetivos do conferencista, é necessário fazer uma boa leitura (competência do sujeito), considerando as reações da platéia, o ritmo, as pausas, etc. (competência relacional) (Macedo, 2005).

As três formas de competência não se anulam necessariamente, pois referem-se a dimensões diferentes e complementares de uma mesma realidade. Entretanto o conceito de competência relacional reflete sempre um agir e pensar sobre determinadas situações que são inéditas afinal a platéia, o jogo e conferência jamais serão as mesmas 
e reproduzirão as mesmas situações. Nesse sentido, a idéia de competência relacional, coaduna com a idéia de competência cognitiva que são ações e operações que o sujeito utiliza para estabelecer relações entre os objetos, situações, fenômenos e pessoas que deseja conhecer.

Entretanto, Macedo (2005) ainda desenvolve mais as diferenças entre habilidades e competências. Para este autor, a diferença entre ambas, em uma primeira aproximação, depende de um recorte, ou fazendo um contraponto com a Geografia, depende da escala de análise. Vejamos como Macedo busca diferenciar esses dois conceitos.

Resolver problemas, por exemplo, é uma competência que supõe o domínio de várias habilidades. Calcular, ler, interpretar, tomar decisões, responder por escrito, etc., são exemplos de habilidades requeridas para a solução de problemas de aritmética. Mas, se saímos do contexto de problema e se consideramos a complexidade envolvida no desenvolvimento de cada uma dessas habilidades, podemos valorizá-las como competências que, por sua vez, requerem outras tantas habilidades.

Para dizer de um outro modo, a competência é uma habilidade de ordem geral, enquanto a habilidade é uma competência de ordem particular, específica. Calcular, ler, interpretar, são habilidades, entretanto, coordenar estas habilidades e tomar decisões é o que Lino de Macedo chama de competência relacional.

Lopes (2001) afirma que as competências requerem a produção de habilidades, um "saber fazer" necessário ao exercício profissional. As competências não têm um conteúdo em si de direito são dispositivos que buscam regulamentar os conteúdos localizados em outros campos do conhecimento especializado. Assim, as competências agem, traduzindo determinado conteúdo em uma habilidade. Na medida em que as habilidades e competências a serem formadas exigem conteúdos de diferentes disciplinas a sua organização tende a ser feita por módulos, com objetivo de englobar conteúdos e atividades que sejam capazes de formar determinado conjunto de habilidades.

Entendemos que da forma como foram apresentadas e formuladas as competências e habilidades do documento de Reorientação Curricular, não coaduna com os preceitos sobre o tema formulado nos documentos oficiais do Ministério da Educação, com destaque para os PCNEM. Fica claro que um currículo formado por habilidades e competências busca integrar as diversas disciplinas, daí que nos PCNEM 
conceitos como interdisciplinaridade, situação-problema e contextualização aparecerem de forma a nortear toda a proposta curricular.

Na nossa compreensão, o que o documento chama de habilidade e competência, na prática, é o objetivo de se ensinar aquele conteúdo. Nesse sentido adquirir e aprender conteúdos torna-se o objetivo principal do ensino de Geografia e isto difere de uma pedagogia baseada no desenvolvimento de habilidades e competências que transforma os conteúdos em instrumentos que levarão os alunos ao desenvolvimento das mesmas.

$\mathrm{Na}$ reorientação curricular para a Geografia as competências e os conteúdos sequer foram hibridizadas dos documentos oficiais do MEC. Os seus autores, ao que parece, numa tentativa de consenso, adaptaram e copiaram os "velhos" objetivos de ensino em competências e habilidades. Segundo a teoria e a História curricular, as competências se utilizam de conteúdos múltiplos, mas não se aproximam das disciplinas especificamente, as competências seriam "supra disciplinares", seriam comportamentais e não essencialmente disciplinares como estas apresentadas neste documento. Nele, há uma tentativa de tornar as competências disciplinares, uma vez que todas remetem a feições disciplinares e não a feições interdisciplinares. As competências listadas no Documento remetem a conhecimentos específicos de Geografia, mas não diríamos que sequer são competências da Geografia.

São aspectos como estas que deixam dúvida sobre a coerência interna do documento de reorientação curricular. Parece que não houve no processo de formulação documento um maior estudo que buscasse organizar princípios teóricos e metodológicos mias do que isso, até mesmos conceitos mais claros.

Entendemos que toda essa confusão conceitual, em parte, possui sua origem na própria natureza do documento de Reorientação Curricular que foi construído em um pouco mais de três meses e possui a intencionalidade de criar um programa único para as escolas. Apesar de, nas suas linhas, o documento afirmar que houve uma ampla discussão com os professores da rede, e que aos mesmos foram enviados questionários a todas as escolas para critica e sugestões ${ }^{39}$, fica latente que é impossível uma discussão aprofundada e eficiente acerca de um tema de tamanha importância - a construção de um currículo para uma rede de mais de 1600 escolas em pouquíssimo tempo.

\footnotetext{
${ }^{39}$ Segundo a Secretaria de educação, uma redação preliminar da proposta foi encaminhada às escolas da rede pública estadual em novembro de 2004. Após discussões, o documento foi reapresentado as escolas em fevereiro de 2005.

Essa discussão preliminar foi iniciada em reuniões de trabalho em 27 de novembro e 4 de dezembro de 2004, e teve continuidade em reuniões nas escolas, no envio de sugestões e críticas pelos professores, e a conseqüente leitura e incorporação destas sugestões pela equipe de autores. (SEE-RJ, 2006: 13)
} 
Na prática, apesar de buscar toda uma formulação teórica nos preceitos dos PCNEM, a visão de currículo que predomina no documento de Reorientação Curricular é a mais tradicional possível, existe uma limitação tanto na compreensão de currículo, mas na concepção de currículo. Na prática o Documento incorpora a noção de currículo como um conjunto de conteúdos e disciplinas.

É um documento que segue os modelos tradicionais de currículo de base tecnocrática como os de Bobbit e Tyler, seus fundamentos são de ordem meramente técnica, um conjunto de conteúdos e objetivos a serem ensinados. É um currículo que tem a pretensão de ser neutro, com fundamentos científicos e apresenta-se ao professorado de forma desinteressada, mas no seu cerne estão embutidas profundas relações de poder e hierarquização. Nesse sentido, os conteúdos são dados como inquestionáveis seguindo certa tradição "tradição geográfica" e a preocupação central reside nas formas dos estudantes absorverem os conhecimentos. É por isto que o mesmo propõe uma seriação bem definida, clara, objetiva e passível de ser mensurada.

\subsubsection{A Reorientação Curricular: o "coração" de um projeto político}

Para Sacristán (1998) o sistema curricular é objeto de regulações que são econômicas, políticas e administrativas. Cabe ao currículo o interesse político básico de controlar a educação como sistema não só de ordem técnica e administrativa, mas, também, de forma ideológica. César Coll (1996) afirma que a elaboração de um currículo ocupa um lugar central nos planos de reforma educacional e que freqüentemente ele seja considerado como ponto de referência para guiar outras atuações como a formação inicial e permanente do corpo docente, organização dos centros de ensino e a confecção de materiais didáticos.

Nesta concepção de currículo os dois autores convergem para uma mesma direção, que o currículo é o centro das políticas educativas e das reformas educacionais. Partilhamos também desta concepção. Entretanto, a Reorientação Curricular é marcada por uma política neoliberal, combatida pelos profissionais da educação. Vários objetivos propostos nas linhas deste documento, na verdade, servem de mera retórica e encobrem suas verdadeiras intencionalidades.

Um dos principais objetivos apresentados por este Documento, ou um dos seus principais objetivos, dizia que o mesmo deveria criar orientações para nortear o 
exercício docente e assim ser capaz de contribuir para melhoria dos padrões de qualidade de ensino:

Estabelecer uma reorientação curricular significa definir parâmetros e linhas, a partir de idéias e pressupostos, discutidos e compartilhados pelas escolas, que contribuam para uma efetiva, construção do Projeto Político Pedagógico da escola e na construção do currículo de cada escola, que devem incorporar suas condições e singularidades sem perder de vista o direito de todos a uma educação de qualidade. (RJ, 2006: 15)

Em vários momentos a Reorientação Curricular demonstra ter como objetivo central "ser para as escolas da rede precisamente uma orientação curricular" (RJ, 2006:15). Para seus autores, o Documento busca nortear o processo de elaboração e construção do planejamento político pedagógico e do currículo das escolas da rede. Nesse sentido, toda escola deve elaborar seu projeto político pedagógico, e o seu próprio currículo e programas curriculares, respeitando as orientações propostas pela secretaria de educação.

Entretanto, pela incoerência metodológica apresentada na área de Geografia, questionamos este princípio do Documento de que a sua finalidade central é de apenas criar orientações para as escolas. Este argumento não é condizente com a forma como a Reorientação Curricular é apresentada à comunidade escolar. Essa compreensão parte do princípio que as escolas não podem formar seus próprios programas e currículos se os mesmos já vieram prontos, sobretudo o primeiro. Assim como não é possível formar um programa para o ensino de Geografia de uma determinada unidade escolar, respeitando a diversidade no seu entorno e a realidade vivida pelos educandos, quando o mesmo já vem completamente acabado e direcionado através de uma lista de conteúdos e temas definidos por séries e segmento educacional.

O objetivo central do Documento, sempre esteve diretamente entrelaçado ao "Programa Nova Escola". Seu objetivo foi servir de ponto de referência para guiar determinadas atuações dentro deste programa, como a avaliação e a busca pelas mesmas metas de ensino. Seu papel foi constituído para determinar o caminho, a trajetória que os professores deveriam percorrer em suas aulas. O currículo nesse sentido deveria guiar o trabalho do professor. Seu papel foi o de servir de parâmetro para avaliação das escolas. 
No "Programa Nova Escola" as unidades escolares eram avaliadas anualmente através de uma prova dirigida aos alunos com o objetivo de aferir o aproveitamento e o rendimento cognitivo dos mesmos. Esse processo de avaliação foi construído, tendo como norte, os conhecimentos e saberes disciplinares propostos na Reorientação Curricular. Avaliam-se os conteúdos propostos pelo currículo. São mais de 1600 escolas que precisam seguir os mesmos conhecimentos.

Aferir e quantificar os conhecimentos adquiridos por parte dos alunos é engrenagem fundamental no programa de avaliação das escolas como explicitado no capítulo anterior. O objetivo central deste programa foi atrelar o salário dos professores a uma lógica de produtividade. Sendo assim, recebia um maior salário os professores pertencentes a uma escola cujos alunos obtiveram maior nota no sistema de avaliação.

Sobre a intenção explicitada no Documento de orientar a construção do projeto político pedagógico para as escolas, entendemos que a argumentação jamais foi pertinente, já que as unidades escolares sempre foram avaliadas anualmente de acordo com as metas e padrões estabelecidos pela secretaria de educação explicitados pelo “Programa Nova Escola". Não é possível falar em autonomia de uma escola passando pela construção do seu projeto político pedagógico em conjunto com a comunidade, se a mesma tem que seguir um receituário administrativo, pedagógico e político.

No "Programa Nova Escola" as unidades escolares sempre foram obrigadas a cumprir metas pré-determinadas pelo governo estadual e a gestão dos seus recursos eram direcionadas para atingir o alcance dessas metas. É nesse sentido que avaliamos que a autonomia escolar não é possível de existir no contexto citado e caminha na direção oposta das Diretrizes Curriculares Nacionais quando esta afirma que:

O exercício pleno da autonomia se manifesta na formulação de uma proposta pedagógica própria, direito de toda instituição escolar. Essa vinculação deve ser permanentemente reforçada, buscando evitar que as instâncias centrais do sistema educacional burocratizem e ritualizem aquilo que no espírito da lei deve ser, antes de mais nada, expressão de liberdade e iniciativa, e que por essa razão não pode prescindir do protagonismo de todos os elementos da escola, em especial dos professores.

A proposta pedagógica deve refletir o melhor equacionamento possível entre os recursos humanos, financeiros, técnicos, didáticos e físicos, para garantir tempos, espaços, situações de interação, formas de organização da aprendizagem e inserção da escola no seu ambiente social, que promovam a aquisição de conhecimentos, competências e valores 
previstos na lei, apresentados nestas diretrizes, e constantes da sua proposta pedagógica. (Brasil, 2002: 84-85).

Quando o "Programa Nova Escola" cria um conjunto de objetivos e metas para as escolas, entendemos que a autonomia fica sacrificada e sua proposta de implementação vira uma mera peça de decoração. São essas argumentações e dados explicitados nesta pesquisa que nos levam ao entendimento de que o princípio central do documento de Reorientação Curricular sempre foi ser um currículo homogeneizador, que buscou direcionar as unidades escolares a perseguir as metas e padrões estabelecidos pela SEE-RJ. Seriam essas metas que garantiriam uma suposta qualidade da educação na rede pública de ensino. E essa qualidade passaria por uma proposta de seriação que visa a uniformização do conhecimento, ainda que apele para a argumentação de resolver o problema dos alunos que se transferem de uma a escola para outra. Ora, esse argumento é apenas um pano de fundo que encobre a real intenção desse programa, a construção de uma escola nos moldes e princípios do ideário neoliberal. 


\section{Considerações Finais.}

As teorias de currículo e as teorias educacionais estão recheadas de afirmações que prescrevem como as coisas deveriam ser. Não existe um único entendimento do que seja o currículo, assim como não há e nunca haverá uma única Geografia escolar e acadêmica. Um currículo é sempre o resultado da seleção de um universo mais amplo de conhecimentos e saberes, do qual seleciona-se aqueles elementos que vai constituilo. Ou seja, todo currículo, quando nasce, como é o caso da Reorientação Curricular já tem decidido por quais conhecimentos devem ser selecionados. $\mathrm{O}$ que se busca fazer depois é justificar por que esses conhecimentos e não outros devem ser selecionados.

Nesse sentido Silva (2002) contribui de forma significativa com o entendimento sobre as teorias curriculares. Para o autor toda vez que se pensa um currículo, inevitavelmente se pensa o tipo de conhecimento considerado importante justamente a partir de descrições sobre o tipo de pessoas que se consideram ideal: Qual o tipo de ser humano desejável para um determinado tipo de sociedade? Será a pessoa otimizadora e competitiva dos atuais modelos neoliberais de educação? Será a pessoa ajustada aos ideais de cidadania do moderno estado-nação? Ou ainda, será a pessoa desconfiada e crítica dos arranjos sociais existentes preconizada nas teorias sociais críticas? A cada um desse modelo de ser humano corresponderá um tipo de conhecimento, um tipo de currículo.

Afinal, um currículo busca precisamente modificar e/ou construir as pessoas que vão "seguir" aquele currículo. E assim ocorre com os currículos de Geografia, com o ensino desta ciência na escola.

Desde o período da institucionalização da Geografia universitária no Brasil que ocorreu com a criação dos cursos desta ciência, em São Paulo (1934) e no Rio de Janeiro (1935), a Geografia escolar esteve associada ao desenvolvimento de noções de pátria e seu principal papel na escolar foi o de atender a projetos nacionalistas através da caracterização das paisagens e da discrição dos lugares. Por um longo período a Geografia esteve ajustada aos ideais de cidadania do moderno estado-nação preconizada como projeto hegemônico das elites emergentes da época.

Durante a década de 1970 houve uma revisão das bases teóricas e metodológicas da Geografia brasileira e isso produziu repercussões no ensino desta ciência. A Geografia Tradicional de caráter funcionalista e positivista que imperou sozinha nas 
escolas e nas universidades passa a ser questionada nos seus fundamentos e no papel que desenvolve na sociedade. A partir deste período, entra em cena a busca por um ensino de uma Geografia Nova, com base em fundamentos críticos.

A Geografia Crítica não só a acadêmica, mas também a escolar passa a considerar o homem como sujeito e não como um objeto do processo histórico; propõe que não separe a sociedade da natureza e que se ensine uma ciência para os alunos que sirva aos seus interesses e não aos interesses de quem detêm o poder. Essa nova Geografia escolar propõe na sua ação pedagógica que o espaço geográfico a ser ensinado tenha como referência o "espaço real" o "espaço vivido". Nesse sentido, a Geografia e os currículos desta ciência são ajustados para a formação de indivíduos desconfiados e críticos dos arranjos sociais existentes, preconizada nas teorias sociais críticas.

Esse momento foi de intenso debate político não só na seara geográfica, mas na sociedade brasileira como um todo. As transformações sociais, políticas e econômicas que ocorreram no Brasil, contribuíram para fortalecimento dos movimentos sociais, do sindicalismo e dos partidos de esquerda. Foi um momento de grandes questionamentos por parte da sociedade civil sobre as formas de poder exercidas e que refletiram na escola, nos currículos e na Geografia ensinada.

Esse debate muito intenso chega às escolas, construídos pelos professores, aparece nos guias curriculares da época e nos conteúdos dos livros didáticos. Resende (1986), nesse ponto, contribuiu significativamente com este trabalho, quando deixa claro que opção deveria ser feita no ensino desta disciplina. Continuar reproduzindo, na escola, uma Geografia positivista, naturalista em que o homem como ser social concreto estava excluído, ou avançar por uma nova concepção teórico-metodológica que se valoriza o "espaço real" e o saber popular dos educandos como ponto de partida. Nesta opção está uma integração dialética que permite construir um ensino desta ciência que parte do particular e busca nas explicações mais gerais da construção do espaço geográfico pelas contradições do capital. Nesse sentido os conteúdos deveriam ser transformados e adaptados à realidade local.

Percebemos ao longo de nossa pesquisa que esse debate não foi travado no processo de construção do documento de "Reorientação Curricular" para a Geografia. Afinal, nunca houve dialogo de fato com os professores desde quando os conteúdos foram listados na primeira versão em 2004, até ser concluída a versão final em 2006 nenhuma linha foi modificada. 
O debate de caráter teórico-metodológico, a concepção de ciência e de escola, pelo que vimos, nunca foi prioridade para os autores do Documento. Essa discussão não foi relevante e o mais interessante foi adotar a Geografia dos velhos manuais didáticos, a Geografia reificada no mercado editorial. O mercado editorial que forma o nosso verdadeiro currículo oculto.

Nesse sentido, Lopes (2008) e Apple $(1989,2001)$ deram uma contribuição significativa a esta pesquisa quando afirmam que o livro didático sempre foi entendido como a proposta capaz de garantir a qualidade de ensino por intermédio da regulação do trabalho do professor em sala de aula. Foi assim com o os manuais de Aroldo Azevedo que influenciaram profundamente a Geografia escolar por décadas. Foi assim, no movimento de renovação da ciência geográfica, com autores que se apropriaram do nome dado ao próprio movimento, como a Geografia Crítica de William Vesentini e Vânia Vlach. É assim atualmente através do Programa Nacional do Livro Didático que classifica os livros de acordo com os Parâmetros Curriculares e as Orientações Curriculares para o ensino fundamental e médio em nível nacional.

Os livros didáticos mais vendidos no mercado editorial tem que coadunar com as políticas impostas pelo governo federal. É através deste grande mercado editorial que as políticas curriculares são viabilizadas e os novos discursos produzidos nos contextos globais e organismos internacionais ganham forma. Ou como afirma Alice Casemiro Lopes $(2001,2008)$ são recontextualizados e hibridizados ganhando novos sentidos em escala local. Qualquer livro didático atualmente, no Brasil, para ser vendido no mercado e comprado pelo governo federal tem quer explicitar de forma clara o discurso do ensino por habilidades e competências associado à lógica interdisciplinar.

As políticas curriculares nacionais e os seus discursos só conseguem ser viabilizadas no currículo em ação, aquele realizado pelos professores na prática cotidiana de sala de aula, se estiverem presentes nos manuais didáticos, afinal são os manuais que oferecem um roteiro que legitima os discursos produzidos. É pelo livro didático que se garante, em grande parte, o que precisa ser ensinado, é através dele que se implementa o currículo, tanto como proposta quanto como prática.

Como a Reorientação Curricular busca construir seus discursos nos PCNEM é natural que os conteúdos apresentados - e a Geografia posta - em ação siga o critério dos manuais mais utilizados como explicita o documento. Esses manuais são os mais vendidos por que viabilizam as reformas. No entanto não é só isto que explica essa vendagem. Eles são os mais vendidos porque de alguma forma expressam a "tradição 
seletiva" como afirma Michael Apple, trazem no seu interior a nossa "tradição geográfica". Isso fica latente através dos recortes regionais apresentados por série, os velhos recortes da Geografia lablachiana e o seu ensino reificado no padrão NaturezaHomem-Economia.

No entanto, a reorientação curricular para a Geografia busca mostrar algo de "novo" - uma orientação curricular desta ciência por habilidades e competências. Porém, esse "novo" é posto apenas como um modismo. O "novo" na prática é o velho travestido, os velhos objetivos do ensino. Diríamos que essas habilidades e competências sequer foram hibridizadas, retiradas de um contexto, reelaboradas e ganharam novos sentidos e forma. Os objetivos dos conteúdos, como num "passe de mágica" tornaram-se habilidades e competências porque é assim que o MEC "exige" um ensino contextualizado e integrado.

Ou seja, tanto a Geografia Crítica quanto a Geografia Tradicional refletem de alguma maneira os contextos políticos da sociedade brasileira. No mesmo sentido, todo currículo expressa uma política educacional e todas as transformações curriculares expressam mudanças de caráter político e isso não é diferente com o programa de Reorientação Curricular. Esse documento é um elo, um componente central de ordem institucional, que faz parte de todo um projeto político, formulado e pensado em escala global, que busca mudanças e transformações na rede estadual de ensino do Rio de Janeiro. Mudanças essas que surgem de organismos multilaterais e de seus técnicos como os do Banco Mundial e se cristalizam pelos países emergentes como o "Programa Nova Escola". Programas como estes visam construir uma escola otimizadora e competitiva dos atuais modelos neoliberais de educação e, consequentemente, um indivíduo que pense e naturalize esses preceitos.

Essas mudanças e transformações no mundo da educação ocorrem em resposta às transformações que ocorrem no mundo do trabalho. Torna-se necessário pensar novas políticas educacionais que busquem formular uma escola mais flexível, que atenda as novas exigências empresarias. É pela educação que se busca formar trabalhadores com altas habilidades e a capacidade de absorver as inovações tecnológicas vigentes do período técnico-científico. Essas políticas educacionais ocorrem no Brasil e em diversos países do mundo pelo campo das políticas curriculares. Afinal, como afirmam Moreira e Candau (2006), o currículo é o coração da escola, o espaço educacional onde todos atuam e é por intermédio dele que as "coisas" acontecem. 
Não obstante, desde que os preceitos neoliberais foram implantados no Brasil de forma avassaladora através do Governo de FHC e do PSDB em conjunto com o PFL, atualmente denominado de DEM, foram realizadas um número significativo de reformas curriculares que através de políticas de avaliação dos estudantes e dos livros didáticos tornam-se de fato implementadas e viabilizadas.

Os Parâmetros Curriculares Nacionais para o ensino fundamental e médio e as Diretrizes Curriculares Nacionais nascem nesse contexto e trazem no seu cerne a lógica da organização curricular que valoriza a formação de habilidades e competências. É a partir dessas reformas curriculares que se instaura um discurso regulador, no qual a escola deve "ensinar para a vida", "para a utilidade prática" que pode ser traduzido para um mercado de trabalho mais flexível e terceirizado.

O Currículo de Geografia inserido dentro da Reorientação Curricular da SEERJ abarca todas essas premissas: ele é construído por dentro de uma lógica que visa "formatar" um indivíduo competitivo que tenha a capacidade de "aprender a aprender" e tenha dinamismo em um "saber fazer", não para ser um indivíduo crítico dos arranjos sociais existente, ou uma pessoa com ideais humanistas. Esse currículo "para fora" expressa um projeto mais amplo que nasce em escala global, mas entendemos que se realiza em escala local, por dentro do "Programa Nova Escola". No seu interior, o que existe são preceitos, discursos que se apresentam como novos - como a interdisciplinaridade - e o ensino por competências e habilidades. Nesse sentido o currículo tende a buscar uma educação integrada e integradora, é um currículo para o ensino fundamental e médio que na sua formatação torna-se cópia imperfeita dos PCNs subdividido em grandes áreas do conhecimento com objetivo de aproximar as disciplinas. Porém, no seu interior, torna-se uma lista de conteúdos e um currículo tradicional.

Seu objetivo é avaliar o trabalho pedagógico dos professores e tornar-se o “coração" do Programa Nova Escola.

É seguindo as suas prescrições, seus conteúdos, séria à série, como um grande manual-cartilha que a rede como um todo alcançaria a tão sonhada qualidade e os professores, em troca, serão remunerados segundo a lógica do mercado, com todos seguindo as mesmas metas e padrões preestabelecidos.

Para finalizar, apesar de a Reorientação Curricular buscar toda formulação teórica nos preceitos dos PCNEM e se apoiar nas DCNs, a visão de currículo que 
predomina no documento é a mais tradicional possível, existindo uma limitação não só na compreensão e na definição de currículo, mas também na concepção de currículo.

Na prática a Reorientação Curricular incorpora a noção de currículo como um conjunto de conteúdos e disciplinas. É nesta mesma linha de pensamento que o currículo da SEE-RJ se assemelha com as propostas de currículo neoliberais iguais a do Banco Mundial para os países emergentes. A Reorientação Curricular é desenhada de forma centralizada, vertical com conteúdos definidos de forma homogênea e prescritiva para toda rede pública estadual. Nesse sentido, existe uma similaridade entre a concepção de currículo do Banco Mundial e a Reorientação Curricular. Para o Banco Mundial a mudança curricular equivale essencialmente à mudança nos conteúdos em vez de mudanças nas formas de se fazer educação, ou seja, pensar o currículo como o centro da escola, o currículo que traz toda uma concepção de escola, de sociedade e de cidadão que se deseja formar. A concepção de currículo do Banco Mundial reforça a tradicional separação entre conteúdo e método, entre currículo e pedagogia.

Outra similaridade importante da Reorientação Curricular com as reformas curriculares proposta pelo Banco Mundial reside na recomendação de que o processo de elaboração e desenvolvimento do currículo tem que ser uma tarefa restrita ao poder central ou regional, sem a participação local (participação da comunidade escolar). A reforma curricular da SEE-RJ segue estes princípios, mesmo quando o documento afirma o contrário - que os professores foram consultados através de um questionário enviado às escolas no período de dezembro de 2004 a janeiro de 2005 . Afinal, não é possível acreditar que essa consulta tenha um caráter propositivo e participativo dentro de um período de tempo onde os professores encontram-se praticamente em recesso ou férias. 


\section{Bibliografia de Referência}

ALMEIDA, Rosângela Doin de, PASSINI, Elza Yasuko. O espaço geográfico: ensino e representação. $15^{\circ}$ ed. São Paulo: Contexto, 2006. - (Repensando o Ensino).

ANDERSON, Perry. Balanço do Neoliberalismo. In: SADER, Emir (org.) PósNeoliberalismo: as políticas sociais e o Estado democrático. São Paulo: Paz e Terra, 1995.

APPLE, Michael. Ideologia e currículo. São Paulo: Brasiliense, 1982.

Educação e poder. Porto Alegre: Artes Médicas, 1989.

Repensando ideologia e currículo in: MOREIRA, A. F. B. e SILVA,

T. T. (Orgs.). Currículo, cultura e sociedade. São Paulo: Cortez, 1994.

Política cultural e educação. 2 ed. São Paulo: Cortez, 2001

AZEVEDO, Aroldo de. Geografia do Brasil: bases físicas, vida humana e vida econômica. $4^{\circ}$ ed. São Paulo: Companhia Editora Nacional, 1971.

BRASIL, Secretaria de Educação Fundamental. Parâmetros Curriculares Nacionais: Geografia, Brasília: MEC/SEC, 1997.

, Secretaria de Educação Média e Tecnologia. Parâmetros curriculares nacionais: ensino médio: Geografia. Brasília: MEC; SEMTEC, 2002.

PCN + Ensino Médio: orientações curriculares complementares aos Parâmetros curriculares Nacionais - Ciências Humanas e suas Tecnologias. Secretaria de Educação Média e Tecnologia - Brasília: MEC; SEMTEC, 2002

, Exame Nacional do Ensino Médio (Enem): fundamentação teóricometodológica / Instituto Nacional de Estudos e Pesquisas Educacionais Anísio Teixeira. - Brasília: O Instituto, 2005. 
CACETE, Núria Hanglei. A AGB os PCN’s e os professores. In: CARLOS Ana Fani Alessandri \& OLIVEIRA Ariovaldo Umbelino de. (orgs.). Reformas no mundo da educação: parâmetros curriculares e geografia. São Paulo: Contexto, 1999.

, Núria Hanglei, PAGANELLI, Tomoko Iyda e PONTUSCHKA, Nídia Nacib. Para ensinar e aprender Geografia. São Paulo: Cortez, 2007.

CAMPOS, Eduardo. O contexto espacial e o currículo de geografia no ensino médio: um estudo em Ilhabela. Dissertação de Mestrado. São Paulo: FEUSP, 2005.

CANDAU, Vera Maria, MOREIRA, Antônio Flávio Barbosa. Currículo, Conhecimento e Cultura. In: Indagações Sobre Currículo. Ministério da Educação - SEB. Novembro de 2006.

CARLOS Ana Fani Alessandri \& OLIVEIRA Ariovaldo Umbelino de. (orgs.). Reformas no mundo da educação: parâmetros curriculares e geografia. São Paulo: Contexto, 1999.

CARLOS Ana Fani. (org.). A Geografia na sala de Aula. São Paulo: Contexto, 2001.

CASTELLAR, Sonia. Educação geográfica: teorias e práticas docentes. São Paulo: Contexto, 2005.

CAVALCANTI, Lana de Souza. Geografia Escola e Construção de Conhecimentos. Campinas: Papirus, 1998.

Geografia e práticas de ensino. Goiânia: Alternativa, 2002.

COLL, César. Psicologia e currículo: Uma aproximação psicopedagógica à elaboração de currículo escolar. São Paulo: Editora Ática. 1996. 
\& MARTÍM Elena \& Cols. Aprender conteúdos \& desenvolver capacidades. Porto Alegre: Artmed Editora, 2004.

CORAGGIO, José Luis. Propostas do Banco Mundial para educação: sentido oculto ou problemas de concepção. In: DE TOMMASI, Lívia, HADDAD, Sérgio \& WARDE, Miriam Jorge (orgs). O Banco Mundial e as políticas educacionais. $2^{a}$ ed. São Paulo: Cortez, 1998.

CORREIA, Wilson Francisco \& NOGUEIRA, Sandra Vidal. Reflexões epistemológicas sobre os desafios curriculares emergentes. In: CICILLIANI, Graça Aparecida \& NOGUEIRA, Sandra Vidal (orgs). Educação Escolar: políticas, saberes e práticas pedagógicas. Uberlândia: EDUFU, 2002.

CICILLIANI, Graça Aparecida \& NOGUEIRA, Sandra Vidal (orgs). Educação Escolar: políticas, saberes e práticas pedagógicas. Uberlândia: EDUFU, 2002.

DELUIZ, Neise. O Modelo das Competências Profissionais no Mundo do Trabalho e na Educação. In: Boletim do Senac - SP. Disponível em <http://www.senac.br/BTS/273/boltec273c.htm> Acessado em 10 de setembro de 2008.

DE TOMMASI, Lívia, HADDAD, Sérgio \& WARDE, Miriam Jorge (orgs). O Banco Mundial e as políticas educacionais. 2a ed. São Paulo: Cortez, 1998.

ENGUITA, Mariano Fernández. O discurso da qualidade e a qualidade do discurso. In: GENTILI, Pablo A.A. \& Silva, Tomaz Tadeu da (Orgs.). Neoliberalismo qualidade total e educação. Petrópolis: Vozes. 1994.

GENTILI, Pablo A.A. \& Silva, Tomaz Tadeu da (Orgs.). Neoliberalismo qualidade total e educação. Petrópolis. Vozes. 1994.

HARVEY, David. Neoliberalismo histórias e implicações. São Paulo: Edições Loyola, 2008. 
- Neoliberalismo e educação: manual do usuário. In: SILVA, Tomaz Tadeu e Gentili, P. (Org.). Escola S.A. Brasília: CNTE,1996.

GONÇALVES, Carlos Walter Porto. Reformas no mundo da educação. In: CARLOS Ana Fani Alessandri \& OLIVEIRA Ariovaldo Umbelino de. (orgs.). Reformas no mundo da educação: parâmetros curriculares e geografia. São Paulo: Contexto, 1999.

GOODSON, Ivor F. Currículo: Teoria e História. 2ª ed. Petrópolis: Vozes, 1998.

LACOSTE, Yves. A Geografia: isso serve, em primeiro lugar, para fazer a guerra. $3^{\mathrm{a}}$ ed. Campinas: Papirus, 1993.

LEAL, Maria Edith Pereira. O Programa Nova Escola: Avaliação institucional nas escolas da rede do estado do Rio de Janeiro (2000-2001). Dissertação de mestrado. Niterói: Faculdade de Educação - UFF, 2004.

LEFORT, Isabelle. O ensino de geografia na França. In: VESENTINI, José William (org). O ensino de geografia no século XXI. Campinas: Papirus, 2004. (Coleção Papirus Educação).

LOPES, Alice Ribeiro Casemiro. Conhecimento escolar: ciência e cotidiano. Rio de Janeiro: Ed. UERJ, 1999.

. Competências na organização curricular da reforma do ensino médio. In: Boletim do Senac - SP. Disponível em $<$ http://www.senac.br/BTS/273/boltec273a.htm> Acessado em 10 de setembro de 2008.

. Políticas de integração Curricular, Rio de Janeiro:

Ed. UERJ, 2008.

MACEDO, Lino de. Competências e habilidades: Elementos para uma reflexão pedagógica. In: Exame Nacional do Ensino Médio (Enem): fundamentação teóricometodológica / Instituto Nacional de Estudos e Pesquisas Educacionais Anísio Teixeira. - Brasília: O Instituto, 2005. 
MORAES, Antônio Carlos Robert. A Geografia Tradicional e sua renovação. Borrador n.1. São Paulo: AGB-SP, 1982.

Geografia: pequena história crítica. $3^{\mathrm{a} e d . ~ S a ̃ o ~ P a u l o: ~}$

Editora HUCITEC, 1984.

Geografia e Ideologia nos Currículos do $1^{\circ}$ grau. In:

BARRETO, Elba S. de Sá (org.) Os currículos fundamental para escolas brasileiras. Campinas: Autores Associados; Fundação Carlos Chagas. 1998.

MOREIRA, Antônio Flávio Barbosa. Currículos e Programas no Brasil. Campinas, São Paulo: Papirus, 1990.

\& SILVA Tomaz Tadeu da. Currículo Cultura e

Sociedade. São Paulo: Cortez, 1994.

: Políticas e Práticas. Campinas. São Paulo:

Papirus, 1999.

MOREIRA, Ruy. Pensar e Ser em Geografia. São Paulo: Contexto, 2007.

O círculo e a Espiral - Para a crítica da geografia que se ensina.

Niterói, Edições AGB Niterói, 2004.

Para onde vai o pensamento geográfico. São Paulo: Contexto, 2006.

O Discurso do Avesso (para a crítica da Geografia que se ensina).

Dois Pontos: Rio de Janeiro, 1987.

NAJJAR, Jorge. A disputa pela qualidade da escola: uma análise do programa Nova Escola do estado do Rio de Janeiro. Tese de Doutorado. São Paulo, FEUSP. 2004. 
OLIVEIRA, Ariovaldo Umbelino de (org.). Para onde vai o ensino de geografia? $9^{\circ}$ ed. São Paulo: Contexto, 2005. (Repensando o Ensino).

PONTUSCHKA, Nídia Nacib. Geografia em

Perspectiva: ensino e pesquisa. $3^{\text {a }}$ ed. São Paulo: Contexto, 2006.

PEREIRA, Diamantino. "Geografia escolar: Conteúdos e/ou objetivos?” Caderno Prudentino de Geografia (17). Presidente Prudente: AGB, julho. 1995.

PONTUSCHKA, Nídia Nacib. "Parâmetros Curriculares Nacionais: Tensão Entre Estado e Escola". In: CARLOS Ana Fani Alessandri \& OLIVEIRA Ariovaldo Umbelino de. (orgs.). Reformas no mundo da educação: parâmetros curriculares e geografia. São Paulo: Contexto, 1999.

A Geografia: pesquisa e ensino. In Carlos, A.F.A (org.).

Novos Caminhos da Geografia. São Paulo, Contexto, 2001.

RESENDE, Márcia Spayer. Geografia do Aluno Trabalhador. Edições Loyola: São Paulo, 1986.

RIO DE JANEIRO. Secretaria Estadual de Educação. Reorientação Curricular de Geografia para o Ensino Médio e Ensino Fundamental $2^{\circ}$ segmento: documento preliminar. Livro III. Ciências Humanas. Rio de Janeiro, 2004.

- Secretaria Estadual de Educação. Reorientação Curricular de Geografia para o Ensino Médio e Ensino Fundamental $2^{\circ}$ segmento: segunda versão. Livro III. Ciência Humanas. Rio de Janeiro, 2005.

Secretaria Estadual de Educação. Reorientação Curricular de Geografia para o Ensino Médio e Ensino Fundamental $2^{\circ}$ segmento: versão definitiva. Livro III. Ciências Humanas. Rio de Janeiro, 2006.

ROCHA, Genylton Odilon da. A trajetória da disciplina Geografia no currículo escolar brasileiro (1837-1942). Dissertação de mestrado apresentada na PUC - São Paulo, 1996. 
A Política do conhecimento oficial e a Nova Geografia dos (as) professores (as) para as Escolas Brasileiras (O ensino de Geografia segundo os Parâmetros Curriculares Nacionais). Tese de doutorado apresentada na FFLCH-USP, São Paulo, 2001.

SACRISTÁN, J. Gimeno. O currículo: uma reflexão sobre a prática. $3^{\mathrm{a}}$ ed. Porto Alegre: ArtMed, 1998.

SANTOS, Milton. Por uma Geografia Nova: Da Crítica da Geografia a uma Geografia Crítica. $3^{\text {a }}$ ed. São Paulo: Editora HUCITEC, 1990.

SCARIM, Paulo César. Coetâneos da Crítica: uma contribuição ao estudo da renovação da geografia brasileira. 2v. Dissertação (Mestrado em Geografia), Universidade de São Paulo: São Paulo, 2000.

SILVA, Jorge Luiz Barcelos da. Notas introdutórias de um itinerário interpretativo sobre a formação do pensamento brasileiro. Dissertação (Mestrado em Geografia), Universidade de São Paulo: São Paulo, 1996.

O que está acontecendo com o ensino de Geografia? Primeiras impressões. In Oliveira, Ariovaldo Umbelino de. \& Pontuschka, Nídia Nacib. (orgs.). Geografia em Perspectiva: ensino e pesquisa. $3^{\text {a }}$ ed. São Paulo: Contexto, 2006.

SILVA, Tomaz Tadeu da. Apresentação. In: GOODSON, Currículo: Teoria e História. $2^{\text {a }}$ Edição. Petrópolis: Vozes, 1998.

A "nova" direita e as transformações na pedagogia da política e na política da pedagogia. In: GENTILI, Pablo A.A. \& Silva, Tomaz Tadeu da (Orgs.). Neoliberalismo qualidade total e educação. Petrópolis. Vozes. 1994.

Documentos de identidade. $2^{\mathrm{a}}$ ed. Belo Horizonte:

Autêntica, 2002. 
SOARES, Maria Claro Couto. Banco Mundial: políticas e reformas. IN: DE TOMMASI, Lívia, HADDAD, Sérgio \& WARDE, Miriam Jorge (orgs). O Banco Mundial e as políticas educacionais. $2^{\text {a }}$ ed. São Paulo: Cortez, 1998.

SPOSITO, Maria Encarnação Beltrão. Parâmetros Curriculares Nacionais para o ensino de geografia: pontos e contra-pontos para uma análise. In: CARLOS Ana Fani Alessandri \& OLIVEIRA Ariovaldo Umbelino de. (orgs.). Reformas no mundo da educação: parâmetros curriculares e geografia. São Paulo: Contexto, 1999.

TORRES, Rosa Maria. Melhorar a qualidade da educação básica? As estratégias do Banco Mundial. In: DE TOMMASI, Lívia, HADDAD, Sérgio \& WARDE, Miriam Jorge (orgs). O Banco Mundial e as políticas educacionais. $2^{a}$ ed. São Paulo: Cortez, 1998.

VESENTINI, José William. Por uma geografia crítica na escola. São Paulo, Ática: 1992.

, José William. A geografia crítica no Brasil: uma interpretação depoente. [2001]. Disponível em: <http://www.geocritica.com.br/texto07.htm>. Acessado em 5 de janeiro de 2008.

José William (org). O ensino de geografia no século XXI. Campinas: Papirus, 2004.(Coleção Papirus Educação)

ZABALA, Antoni. Como trabalhar os conteúdos procedimentais em aula. Porto Alegre: Editora Artes Médicas Sul Ltda. 1999. 
ANEXOS 
